DEPARTMENT OF THE INTERIOR

UNITED STATES GEOLOGICAL SURVEY

GEORGE OTIS SMITH, DIRECTOR

BULLETIN 434.

\title{
RESULTS OF SPIRIT LEVELING
}

IN .

\section{DELAWARE, DISTRICT OF COLUMBIA, MARYLAND, AND VIRGINIA}

\author{
1896 TO 1909, INCLUSIVE
}

R. B. MARShALL, Chief Geographer

WORK DONE IN COOPERATION WITH THE STATE OF MARYLAND DURING THE ENTIRE PERIOD AND WITH THE STATE OF VIRGINIA IN PART OF 1908

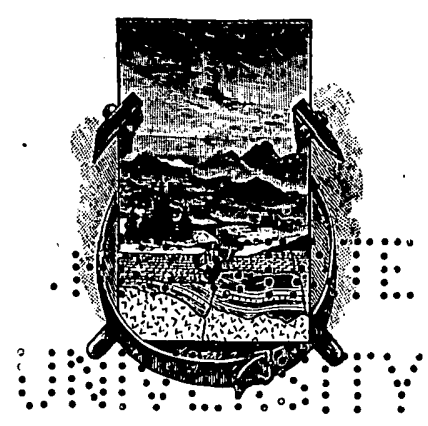

WASHING'TON

GOVERNMENT PRINTING OFFICE

1910 
C. E 15

10

nso. 4394939

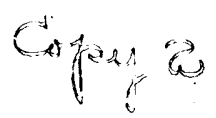

औओ

: 


\section{CONTENTS.}

Page.

Introduction................................................ 5

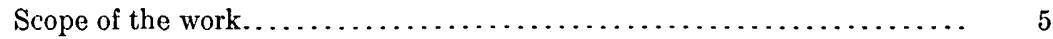

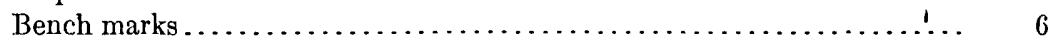

Cooperation and personnel................................. 7

Classification.............................................. 7

Delaware................................................. 7

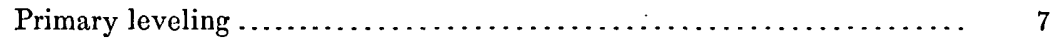

Westchester and Wilmington quadrangles (Newcastle County)....... $\quad 7$

Dover $\left(30^{\prime}\right)$, Ellendale, Frankford, Georgetown, Harrington, Seaford, and Selbyville quadrangles (Kent, Newcastle, and Sussex counties).

District of Columbia . ........................................ 13

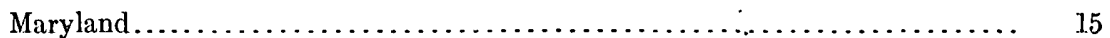

Barclay, Betterton, Cecilton, Chestertown, Choptank $\left(30^{\prime}\right)$, Crapo, Crisfield, Deal Island, Denton, Dover $\left(30^{\prime}\right)$, Drum Point, Harrington, Hurlock, Nanticoke, Ocean City, Oxford, Pittsville, Princess Anne, Salisbùry, Seaford, Snow Hill, St. Michaels, and Tolchester $\left(30^{\prime}\right)$ quadrangles (Caroline, Cecil, Dorchester, Kent, Queen Annes, Somerset, Talbot, Wicomico, and Worcester counties) ...................

Belair, Elkton, Havre de Grace, and Parkton quadrangles (Baltimore,

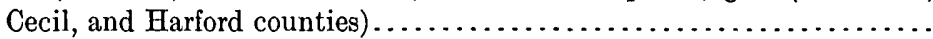

Annapolis, Baltimore, Ellicott, Laurel, Relay, and Westminster quadrangles (Anne Arundel, Baltimore, Carroll, and Prince Georges coun-

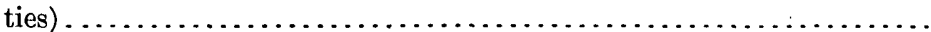

Ijamsville, Mount Airy, Rockville, and Seneca quadrangles (Frederick,

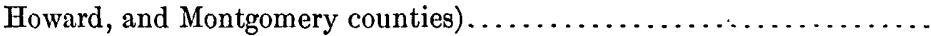

Middletown, and Martinsburg quadrangles (Frederick and Washington

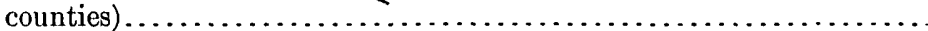

Emmitsburg, Hagerstown, Taneytown, and Williamsport quadrangles (Carroll, Frederick, and Washington counties)....................

Accident, Flintstone, Frostburg, Grantsville, Hancock, Oakland, Pawpaw, and Piedmont quadrangles (Allegany, Garrett, and Washington coun-

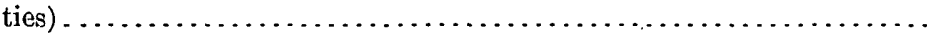

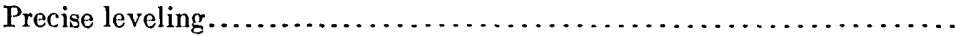

Clarksville, Clifton Forge, Fincastle, Leslie, Lewisburg $\left(30^{\prime}\right)$, Martinsville, Natural Bridge Special, Rocky Mount (30'), and Roanoke $\left(30^{\prime}\right)$ quadrangles (Alleghany, Botetourt, Franklin, Henry, Mecklenburg, and Roanoke counties)..............................

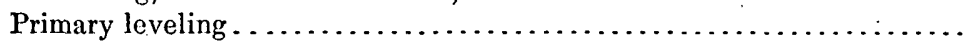

Guilford and Snow Hill quadrangles (Accomac County).............

Hampton, Isle of Wight, Jamestown, Toano, Williamsburg, and Yorktown quadrangles (Gloucester, Isle of Wight, James City, Surrey, Warwick, and York counties)............................. 
Virginia-Continued.

Primary leveling-Continued.

Page.

Appomattox $\left(30^{\prime}\right)$, Boydton, Callands, Chatham, Clarksville, Clover, Leslie, Lynchburg $\left(30^{\prime}\right)$, Moneta, Nathalie, and Virgilina quadrangles (Campbell, Charlotte, Halifax, Mecklenburg, and Pittsylvania counties)

Fincastle and Natural Bridge Special quadrangles (Botetourt and Rockbridge counties)................................

Middletown, Mount Vernon, and Seneca quadrangles (Loudoun and

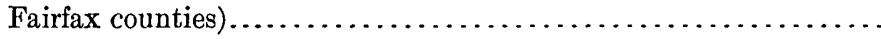

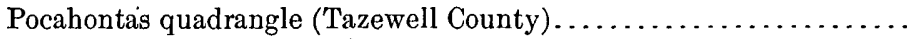

Middlesboro quadrangle (Lee County).

Abingdon quadrangle (Grayson, Russell, Smyth, and Washington

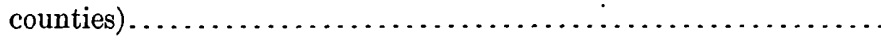

Index. 


\section{RESULTS OF SPIRIT LEVELING IN DELAWARE, DISTRICT OF COLUMBIA, MARYLAND, AND VIRGINIA, 1896 T0 1909, INCLUSIVE.}

R. B. Marshall, Chief Geographer.

\section{INTRODUCTION.}

Scope of the work.-The results herein given are based on a common mean sea-level datum. The main control is the adjustment made in 1903 by the Coast and Geodetic Survey of a great net of precise levels, which combines work of various organizations and covers the eastern half of the United States.

The precise-level lines which lie wholly or partly in the combined area of Delaware, District of Columbia, Maryland, and Virginia are as follows: The Coast and Geodetic Survey lines (1) from Norfolk, Va., to Washington, D. C., and (2) the transcontinental line from Washington, D. C., westward; the Baltimore and Ohio Railroad lines (1) from Philadelphia, Pa., via Wilmington, Del., Relay, Washington Junction, and Cumberland, Md., to Grafton, W. Va., (2) from Relay via Washington to Washington Junction and on the Landenberg branch; and the United States Geological Survey lines (1) from Durham, N. C., to Clarksville, Va., and (2) from Greensboro, N. C., via Buchanan, Va., to Alleghany Station, Va.

All results of spirit leveling in these States previously published by the United States Geological Survey and all later work are included in this report, readjusted, and rearranged by quadrangles. Descriptions and elevations of bench marks are given for all 3 counties in Delaware, for 19 of the 23 counties in Maryland, and for 21 of the 100 counties in Virginia. For convenient reference the descriptions and elevations of bench marks in the District of Columbia established by the Coast and Geodetic Survey, the United. States Engineer Corps, and the Baltimore and Ohio Railroad (none having been established by the United States Geological Survey) are also included in this publication, as well as the results of a double primarylevel line run by the water-resources branch in the valley of the Roanoke River in Virginia from Clarksville to Rockymount. 
To convert the elevations herein given to agree with the 1907 adjustment of the precise-level net, a readjustment would be necessary, correcting the elevations north and west of Washington by amounts in feet, varying gradually from place to place, approximately as follows: Washington 0.00 , Relay -0.17 , Baltimore -0.07 , Havre de Grace +0.10, Washington Junction -0.17, Hagerstown -0.26, Cherry Run -0.28 , Cumberland -0.46 , and Oakland -0.46 . The publication in detail of such readjustment was, however, not considered advisable, because the elevations herein given are in agreement with those given in Bulletin No. 288, containing results of spirit leveling in Pennsylvania, and Bulletin No. 399, containing results in West Virginia, all of which accord with the 1903 adjustment.

Bench marks. - The bench marks, the locations of which are given in the following lists, are mainly of three general forms: First, a circular bronze or aluminum tablet $3 \frac{1}{2}$ inches in diameter and onefourth inch thick, appropriately lettered, having a 3-inch stem cemented in a drill hole, generally in the vertical wall of a public building, a bridge abutment, or other substantial masonry structure. The second form, employed where masonry or rock is not accessible, consists of a hollow wrought-iron post $3 \frac{1}{2}$ inches in outer diameter and 4 feet in length after being split at the bottom and expanded to 10 inches at base, so as to prevent both the easy subsidence of the post and the malicious pulling of it out of the ground. These posts are generally sunk 3 feet in the ground; the iron is heavily coated with asphalt, and over the top of the post is riveted a bronze tablet similar to that described above. The third form consists of a copper bolt 1 inch in diameter and 4 inches long, which is split at one end and expanded in a drill hole in masonry by driving on a brass wedge. But few bench marks of the third class have been used in these States, and their use has now been discontinued.

The numbers stamped on the bench marks represent the elevations to the nearest foot above mean sea level, as determined by unadjusted levels in the field. The notes have since been subjected to changes resulting from the adjustments necessary to close circuits and to those resulting from reduction to mean sea level through readjustment of the precise-level net of the United States. Some of the finally accepted elevations as printed herein therefore differ from those submitted as bench-mark numbers by 1 or 2 feet. This method of numbering bench marks has been adopted, where many level men are working in the same area at the same time, as less liable to lead to confusion in identification of bench marks than any attempt at serial numbering, and because such bench-mark number also gives an approximate statement of the elevation. It is assumed that engineers and others finding these bench marks so stamped in the field will communicate with the Director of the United States 
Geological Survey in order to obtain the accepted elevation to hundredths or thousandths of a foot. Bench marks established under cooperation with the State are stamped with the state name.

Any person finding bench marks in the following lists mutilated or destroyed will confer a favor by notifying the Director, United States Geological Survey, Washington, D. C.

Cooperation and personnel.-The leveling in Maryland was done in cooperation with the State during the years 1896 to 1908, inclusive. In Virginia the only leveling done in cooperation was that in the Virgilina district in 1908. In Delaware none of the work was done in cooperation.

The field work for the years 1896 to 1906, inclusive, was done under the direction of H. M. Wilson, geographer; for the years 1907, 1908, and 1909 under Frank Sutton, geographer; and in 1908 and 1909 under the general supervision of R. B. Marshall, chief geographer.

Credit is given to the various level men directly in charge under the heading of each list.

The office work of computation, adjustment, and preparation of lists was principally done by $\mathrm{D}$. $\mathrm{H}$. Baldwin, topographer, under the immediate supervision of S. S. Gannett, geographer, and since 1907 under the general direction of E. M. Douglas, geographer.

Classification.-The elevations determined by the United States Geological Survey are classified, according to the accuracy of the method of leveling employed in their determination, as precise or primary. Under precise leveling are included lines run in both forward and backward directions, a high-grade instrument being used and special precautions being taken in observations and reduction to correct errors and make the lines continuously good throughout. The allowable limit of error observed by the United States Geological Survey on precise work is represented in feet by the formula $0.017 \sqrt{\mathrm{D}}$, in which $\mathrm{D}$ is the distance between bench marks in miles. Under primary leveling are included lines run mostly single with the $Y$ level, precautions being taken against only. the principal sources of error, and depending upon the closure of circuits for a check. The limit in feet in primary work is represented by the formula $0.05 \mu \overline{\mathrm{D}}$, in which $\mathrm{D}$ is the length of circuit in miles.

DELA WARE.

PRIMARY IEVELING.

Westchester and Wilmington quadrangles.

NEWCASTLE COUNTY.

The elevations in the following list are based on heights of bench marks of the Philadelphia, Baltimore and Washington Railroad derived by adjustment of the railroad company's levels to agree with 
the elevations at Philadelphia and Havre de Grace brought by Baltimore and Ohio precise leveling corrected to accord with the 1903 adjustment elevation at Washington.

The leveling in Westchester quadrangle was done in 1900 by Hargraves Wood; in Wilmington quadrangle in 1904 by J. W. Hodges.

WESTCHESTER QUADRANGLE.

State line CORNer No. 16, via granogue, Centerville, CorNer 10, AND yoRk LyNN, to CORNER 6.

Granogue, in front of freight station; top of rail..................

Feet.

213. 2

Centerville, 2.5 miles northwest of, 1.5 miles west of Line House, Pa., in top of state-line corner 10; bronze tablet stamped " 267 HARRISBURG"...

Hockessin, about 1.1 miles northwest of, 50 feet north of Avondale pike, 50 feet west of lane to Wingate's residence, in field, in top of state-line corner No. 6; aluminum tablet stamped "356 HARRISBURG 1900" .... .

\section{WILMINGTON QUADRANGLE.}

AT WILMington.

Wilmington, at Philadelphia, Baltimore and Washington Railroad station, in step of station master's room; copper bolt. . . . . . . . . . . . . . . .

Wilmington, in northwest front of post-office, 2 feet above pavement; aluminum tablet stamped " 99 ADJ $1903 " \ldots \ldots \ldots \ldots \ldots \ldots \ldots \ldots \ldots$

NEWARK, NORTHEAST VIA CHOATE TO NEWPORT.

Newark, in doorsill of Philadelphia, Baltimore and Washington Railroad

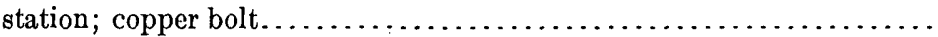

Choate, 0.2 mile east of, on top of large bowlder on south side of road near small bridge; bronze tablet. stamped " 43 ADJ $1903 " . . . \ldots \ldots \ldots . . . .$.

Stanton, in foundation wall of Stanton Hotel, west of ladies' entrance; aluminum tablet stamped " 55 ADJ 1903 " ....................

Newport, 150 feet west of station, on top of small culvert on south of track;

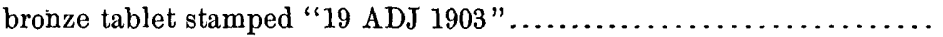

19. 476

NEWPORT, ALONG HIGHWAY SOUTHEAST TO NEWCASTLE; THENCE SOUTHWEST TO RED LION; THENCE SOUTH TO M'DONOUGH.

Newcastle, in northwest corner of post-office building, old court-house; aluminum tablet stamped " 28 ADJ 1903 "

27.868

State Road, 0.1 mile west of post-office, on bridge seat of small highway bridge over Thunder Gush stream, northeast abutment; aluminum tablet stamped " 17 ADJ 1903 "

Red Lion, 0.6 mile south of, on southeast abutment of small bridge near fork of road leading east; aluminum tablet stamped "19 ADJ 1903 "....

St. Georges, on top of retaining wall which was old canal lock; bronze tablet stamped "11 ADJ 1903".

McDonough, 0.5 mile north of, at Boyds Corners, northwest corner of crossroads; corner of yard and garden; iron post stamped "ADJ 601903 "...

60.686 NEWARK, ALONG HIGHWAY SOUTH TO MOUNT PLEASANT; THENCE EAST TO M'DONOUGH.

Couches Bridge, on top of retaining wall on end near southeast side; bronze

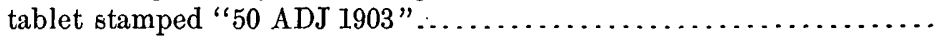

Glasgow, in doorsill of Pencador Church, main entrance; bronze tablet stamped "69 ADJ 1903 "

50. 188

68. 982 
Summit Bridge, post-office, at northeast corner of Buck Hotel; iron post - stamped "72 ADJ 1903".

Feet.

Mount Pleasant, in doorsill of south station office door; aluminum tablet stamped "70 ADJ 1903".

Dover $\left(30^{\prime}\right)$, Ellendale, Frankford, Geo

Georgetown, Harrington, Seaford, and Selbyville quadrangles.

\section{KENT, NEWCASTLE, AND SUSSEX COUNTIES.}

The elevations in the following list are based on tide-gage records made by the Coast and Geodetic Survey at several points in Chesapeake Bay and at Franklin City, Chincoteague Bay, carried through adjoining primary-level work on "Eastern Shore," Maryland, and levels of the Philadelphia, Baltimore and Washington Railroad.

The leveling in Dover quadrangle was done in 1896 by O. L. Pettibone and Charles Goldsborough, and the remainder was done as follows: In 1900, in Harrington and Seaford quadrangles, by T. D. Leonard, and in Seaford quadrangle by C. H. Semper. The leveling in Georgetown and Ellendale quadrangles and additional work in the Frankford; Harrington, Seaford, and Selbyville quadrangles was done in 1908 by H. M. Gillman; jr.

$$
\text { DOVER }\left(30^{\prime}\right) \text { QUADRANGLE. }
$$

BOHEMIA MILLS EAST, VIA MIDDLETOWN, TO ODESSA; THENCE SOUTHEAST TO TAYLORS BRIDGE ROAD; THENCE WEST TO TOWNSEND; THENCE SOUTHWEST TO MASSEY.

Middletown, near station, west side of front corner of National Hotel; bronze tablet stamped " $65 "$. . . . . . . . . . . . . . . . . . . . . . .

Middletown; copper bolt in doorstep of ladies' waiting room of railroad station, stamped "17" (Pennsylvania Railroad bench mark) . . . . . . . .

Odessa, 1.25 miles south of, at fork of road, in foundation of schoolhouse; bronze tablet stamped " 37 ".

Townsend, 3 miles east of, in northwest corner of foundation of shed of John Corbett's small house; bronze tablet stamped " 60 " . . . . . . . . . .

Townsend; copper bolt at southwest corner of hotel, 8 inches from corner

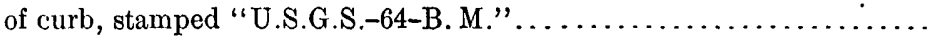

Feet.

65. 684

38. 106

MASSEY, EAST VIA CLAYTON, TO RAYMONDS NECK.

Clayton, on north side of Hotel Stoeckle; bronze tablet stamped " 45 ". ... Whitehall crossroads, Raymonds Neck, in northeast corner of crossroads; iron post stamped " 19 "

20. 066

marydel, Nortieast along pHiladelphia, baltimore aNd Washington railroad, to CLAYTON.

Hartly, in southwest corner of foundation of Joseph Poor's hotel; bronze

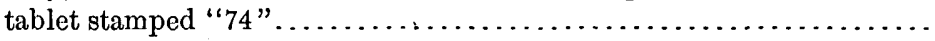

Hazels Corners, in northeast corner of schoolhouse; bronze tablet stamped "70".

Downs Chapel, 0.5 mile west of, east of road, at corner of fence; top of boundary stone. 
CLAYTON, SOUTH TO HARRINGTON.a

Cheswold, in doorsill of ladies' waiting room at station; copper bolt (railroad bench mark) . . . . . . . . . . . . . . . . . . . . . . . . . . .

Cheswold, 250 feet southwest of passenger station, corner of crossroads, in corner of stone; bronze tablet stamped " 43 "....................

Dover, at Philadelphia, Baltimore and Washington Railroad station, in doorsill of ladies' waiting room; copper bolt (railroad bench mark)......

Dover, in south side of post-office; bronze tablet stamped " 34 "..........

Wyoming, at railroad station, in doorsill of ladies' waiting room; copper bolt (railroad bench mark) .................................

Wyoming, 200 feet southwest of station, in east end of frame factory; bronze tablet stamped " 42 ". ................................

Woodside, at station; top of railroad monument (railroad bench mark)....

Woodside, at south end of freight house; iron post stamped " $60 " . . . . .$.

HARRINGTON QUADRANGLE.

WHiteleysburg, EAST to haRRINGTON; theNCE SOUTH ALONG PHILADELPHIA, BALTIMORE AND WASHINGTON RAILROAD TO GREENWOOD.

Harrington, at station, in doorsill of waiting room; copper bolt (railroad

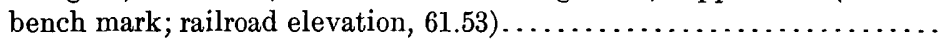

Harrington, in small doorsill of station; aluminum tablet stamped "BALTO $62 "$.

Greenwood, diagonally across track from station, at southeast corner of piazza of F. E. Owens's store; iron post stamped "BALTO 47 ".......

Feet.

44. 870

42.873

59. 316

60.296

GREENWOOD, EAST ALONG MARYLAND, DELAWARE AND VIRGINIA RAILWAY, TO OAKLEY.

Owens station, northwest of railroad road crossing, in east face of brick foundation to porch of frame dwelling owned by C. P. Tatman; aluminum

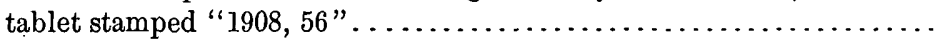

Oakley station, east of wagon road, 200 feet south of track, in north face of northwest corner of foundation to house owned by C. W. Short; aluminum

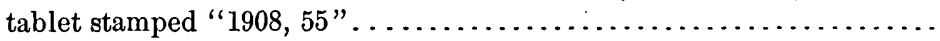

\section{ELLENDALE QUADRANGLE.}

OAKLEY, EAST ALONG MARYLAND, DELAWARE AND VIRGINIA RAILWAY, TO ELLENDALE; THENCE SOUTH ALONG PHILAdElPHIA BALTIMORE AND WASHINGTON RAILROAD TO ROBBINS.

Ellendale, 100 feet northwest of intersection of Maryland, Delaware and Virginia Railway and Delaware, Maryland and Virginia Railroad, in center of west face of foundation to dwelling owned by D. A. Reed; alu-

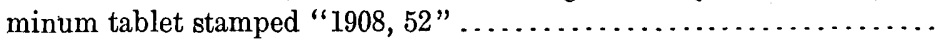

Ellendale, 1 mile south of, 50 feet west of tracks, 300 feet north of property post, in tree stump; nail. ................................

Robbins, 5 feet from southwest corner of railway road crossing at station; in top of stone monument; copper bolt (Pennsylvania Railroad bench

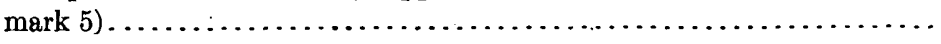

SEAFORD QUADRANGLE.

GREENWOOD, SOUTH ALONG PHILADELPHIA, BALTIMORE AND WASHINGTON RAILROAD, TO SEAFORD; THENCE WEST TO OAKGROVE.

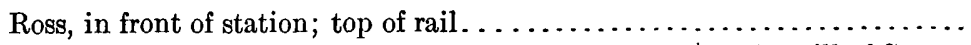

Seaford, at corner of High and Cornwell streets, in stone doorsill of Sussex National Bank; aluminum tablet stamped "BALTO 29 "...........

29. 501

$a$ Bench marks set from Philadelphia, Baltimore and Washington Railroad levels; corrected by adding 0.64 foot. 
Seaford, in stone doorsill of ladies' waiting room at station; top of bolt

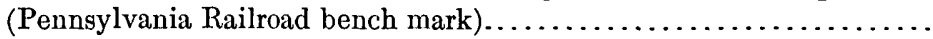

Feet.

11.43

Oakgrove, 0.3 mile west of, north of Philadelphia, Baltimore and Washington Railroad tracks; stone post marking Maryland-Delaware state line; top marked " 47 ".

SEAFORD, SOUTH ALONG PHLADELPHIA, BALTIMORE AND WASHINGTON RAILROAD, TO DELMAR.

Broadcreek, 500 feet east of railroad, 300 feet south of crossroads on main road, in foundation of northeast corner of James Hall's house; aluminum tablet stamped "BALTO 41 ".............................

Laurel, at station, in doorsill of ladies' waiting room; copper bolt (Penn-

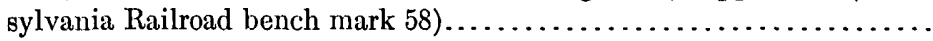

SEAFORD, EAST ALONG HIGWAY, TO POINT 3.1 MILES EAST OF CONCORD.

Blades, at southeast corner of road forks, in root of tree; nail............

Seaford, 1.6 miles east of, at southwest corner of $T$ road south, in root of pine tree; nail.

Concord, at fence corner of Frank Jefferson's property at road south, on stone; chisel mark.

Concord, east of road forks, in root of cedar; nail.

Concord, 1.3 miles east of, 140 feet north of road, in east face of southeast corner of brick pillar under house owned by W. M. Smith; aluminum tablet stamped "1908, 34"

Concord, 2.2 miles east of, at southeast corner of crossroads, in west face of cedar tree; spike.

Knowles crossroads, 2.8 miles west of, 100 feet west of crossroads, west of road, in south side of persimmon tree; nail...................

laurfi, east along highway, to pepper.

Laurel, station, in doorsill of ladies' waiting room; copper bolt (Pennsyl-

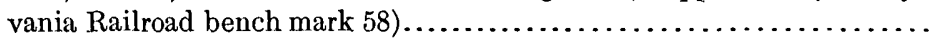

Laurel, east edge of, south of road, 240 feet east of road forks, on top of white marble monument marking city limits; center of letter " $\mathrm{C}$ ".......

Pepper, 2.3 miles west of, north of road, in center of brick pier under south side of frame dwelling of William De Shield's estate; aluminum tablet stamped " 1908,34 ".

GEORGETOWN QUADRANGLE.

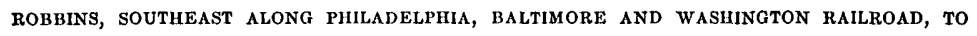
DAGSBORO.

Georgetown, south of track, 5 feet from northwest corner in west face of brick station of Pennsylvania Railroad; aluminum tablet stamped " 1908,57 ".

Stockley, 0.8 mile northwest of, 600 feet west of railroad, in east face of foundation under bay window to left of main window of house owned by Mrs. B. A. Johnstone; aluminum tablet stamped " 1908,47 "..........

Stockley, 2 miles southeast of, 1,020 feet west of milepost " $48-6$," on main road to Millsboro, in west face of brick pillar under southwest corner of house owned by Cyrus Baker; aluminum tablet stamped "1908, 34"....

Millsboro, south of Main street, 100 feet east of tracks, in north face of northwest corner of Millsboro Trust and Savings Deposit Company's building; aluminum tablet stamped " 1908,27 "..................

Dagsboro, 1,160 feet east of station, in west face of southwest corner of First National Bank; aluminum tablet stamped " $1.908,29 " . . . \ldots \ldots$. 
GEORGETOWN, SOUTHWEST ALONG HIGHWAY, TO POINT 3.1 MILES EAST OF CONCORD.

Georgetown, 1 mile southwest of, 250 feet southwest of crossroads, north of road, in root on north side of tree; nail.........................

Georgetown, 1.3 miles southwest of, at southwest corner of $T$ road south,

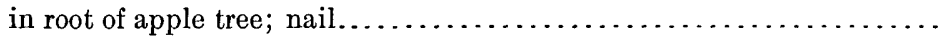

Georgetown, 2.5 miles southwest of, at northeast corner of crossroads, in root of oak tree; nail.

Feet.

48.70

51.34

50.29

Georgetown, 3.2 miles southwest of, north of road, at private road south, in south face of brick foundation of house owned by William P. Pepper; aluminum tablet stamped " 1908,50 ".

Knowles, on stone at northwest corner of crossroads; chisel mark.

Knowles, west of crossroads, north of road, 400 feet west of private road south, in south face of brick foundation of house owned by D. H. Hill; aluminum tablet stamped "1908, 47 "

Knowles, 1.1 miles west of, in center of road forks and crossroads, in root of

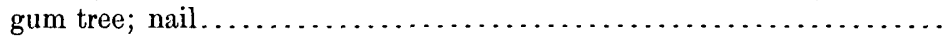

MILLSBORO, SOUTHWEST ALONG HIGHWAY, TO LOWES CROSSROADS; THENCE WEST TO PEPPER.

Millsboro, 0.4 mile southwest of, at road forks, in root at south side of oak tree; nail

Millsboro, 2.3 miles southwest of, at northeast corner of crossroads, on stone post; chisel mark.

Mission, 2 miles east of, at southwest corner of $T$ road west, in east face of brick foundation of porch of house owned by Viola Sirman; aluminum tablet stamped " 1908,38 ".

Mission, 1.4 miles east of, at west corner of crossroads, in root of apple tree;

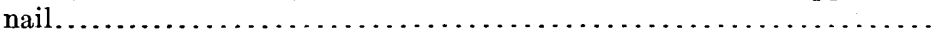

Mission, at northeast corner of crossroads, in root of oak tree; nail........

Mission, 0.7 mile northwest of, southeast of road, 1,540 feet southeast of road forks, in north face of northwest corner of brick pier at northwest corner of house owned by M. H. Mitchell; aluminum tablet stamped " 1908,48 "

Lowes, at northeast corner of crossroads, in root of tree; nail.............

Lowes, north of road, 370 feet west of crossroads, in east face of foundation to porch of house owned by W. A. Cannon; aluminum tablet stamped

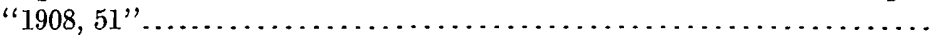

Lowes, 1 mile northwest of crossroads, at road forks, in stump of pine tree; nail

Lowes, 1.9 miles west of crossroads, south of road, third tree to west, in root of large oak tree in front of W. J. West's house; nail.

Lowes, 2.7 miles west of, at northwest corner of crossroads, in root of tree; nail.

Pepper, 1.4 miles east of, north of road, 1,600 feet west of crossroads, in east face of brick foundation to barn owned by T. S. Lescates; aluminum tablet stamped " 1908,44 ".

Pepper, 0.4 mile east of, at northwest corner of crossroads, 50 feet south of house, in root of maple tree; nail.

Pepper, at northeast corner of crossroads, in root of large sycamore tree; nail.

\section{FRANKFORD QUADRANGLE.}

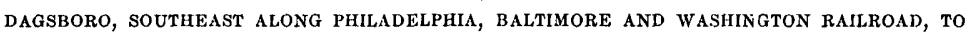
CROSSING 1 MILE SOUTH OF FRANKFORD.

Dagsboro, 0.8 mile south of, on west end of iron drain pipe; painted square. .

Frankford, 250 feet northeast of station, in south face of southwest corner of First National Bank; aluminum tablet stamped " 1908,37 ".........
49. 880

47. 24

41. 68

45. 31

47. 490

50.62

50.571 
SELBYVILLE QUADRANGLE.

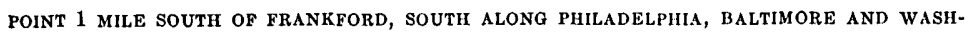
INGTON RAILROAD, TO SELBYVILLE; THENCE WEST TO TIE ON OLD LINE.

Selbyville, in northwest face of buttress to left of entrance of First National Bank; aluminum tablet stamped "1908, 38 ".

Feet.

42.014

\section{DISTRICT OF COLUMBIA. $a$}

MAIN LINE, BALTIMORE AND OHIO RAILROAD.

Milepost "W. 2-Baltimore 38," cross on top of vertical rail section set opposite (bench mark 1 ).

Trinidad yards, southwest end of, in northwest end of northeast abutment of culvert, about 50 feet southwest of telegraph pole 37/13; copper bolt (bench mark 2).

Winthrop Heights, 0.2 mile southwest of, in northeast end of southeast coping of arch culvert opposite telegraph pole 36/16; copper bolt (bench mark 3).

Langdon, 150 feet south west of station, in south west end of nor th west coping of culvert; copper bolt (bench mark 4 ).......................

Feet.

METROPOLITAN BRANCH, BALTIMORE AND OHIO RAILROAD.

Milepost "Washington 1 mile," on top of section rail set vertically in ground between tracks; cross (bench mark 2).....................

Eckington, between the tracks opposite milepost "Washington 2 miles," on top of section rail set vertically in ground between tracks; cross (bench

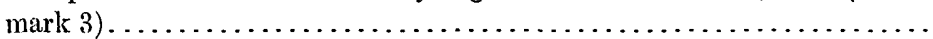

Brookland, between tracks at south end of bridge $2 \mathrm{~A}$, in bridge seat: under grade crossing of the electric car line; copper holt (bench mark $3 \mathrm{~A}$ ).....

Brookland, between tracks at north end of bridge culvert $3 \mathrm{~A}$, in bridge seat;

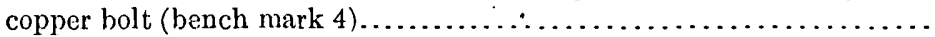

Brookland, about 1 mile northwest of, about 3.8 miles from Washington, west of tracks, south of box culvert, opposite telegraph pole $3 / 25$; copper

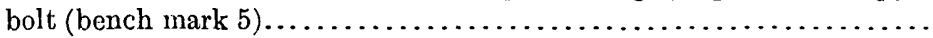

Stotts, on the south abutment of bridge $5 \mathrm{~B}$, in west end of bridge seat; cop-

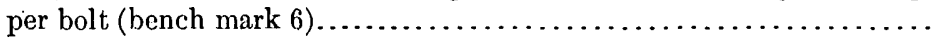

Takoma Park, between tracks on the east abutment of bridge $7 \mathrm{~A}$, in bridge seat; copper bolt (bench mark 7)

107. 448

129. 153

160.668

204. 652

VARIÓUS LOCALITIES.

Navy-Yard, southwest corner of commandant's office, brick column under southwest corner of porch; upper surface of iron plate.............

Capitul, in granite water table under the first window west of the southeast corner of the Senate wing, in the middle of a bronze plate 5 inches square, placed vertically and inscribed "Capitol Bench Mark, U. S. Coast and Geodetic Survey, 1884;" top of bronze bolt.......................

Washington Monument, in a stone on the southwest corner of the top layer of foundation; top of a brass bolt placed vertically, marked " $O$ " (bench mark established and used by the U. S. Engineer Corps in the erection of the monument; the aluminum point of the pyramidion is aaid to be 555

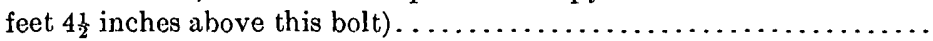

a Bench marks established by the Baltimore and Ohio Railroad, the Coast and Geodetic Survey, and the U. S. Engineer Corps. 
National Museum, north side of main building, on the granite sill of the outer door of main entrance, 5 feet from east side of door, 5 feet from west side of door, $10 \frac{1}{2}$ inches from the north edge of sill, about 1.0 feet from the inner door leading to the Museum; center of cross (bench mark 82)..... Washington No. XI (Georgetown), in northwest coping of north abutment of Aqueduct Bridge over Potomac River; bottom of square inclosing a St. Andrews cross.........................................

Hill, at trigonometrical station, near Washington..................

Navy-Yard Bridge, at east end of north side of northeast corner; curbstone

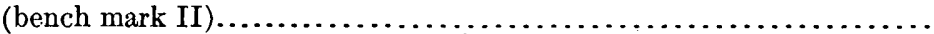

Navy-Yard, on stone around flagstaff near entrance gate; cross (bench mark I or 5 ).

Coast Survey office, new building on New Jersey avenue near B street SE., in vestibule of main entrance; center of central square..............

Navy-Yard, in top of one of the coping stones of wharf or dock on the east side of the boathouse slip, 28* feet south of boathouse, 10 inches from outer edge of stone; center of rude cross and circle (bench mark 8 or $\mathrm{E}$ ).......

Navy-Yard, at main entrance to ordnance office, in north end of granite doorstep (about 8 feet long by 14 inches wide by 8 inches thick) set on 3 feet of concretn: bottom of square hole about 0.15 or 0.0125 foot deep, marked "U.S.... $\square$ G.S.B.M." (bench mark 14).................

Capital Traction Company's buildıng; corner Eighth and M streets SE., at entrance on Eighth street, near southeast corner of foundation; bench

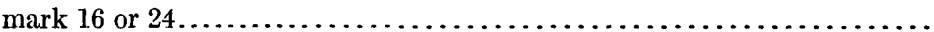

Bruen Mission Church, corner M and Half streets SE., in middle of stone doorsill of M street entrance; center of rude cross (bench mark 22)......

M Street Bridge, at First street SW., in stone abutment on southwest corner,

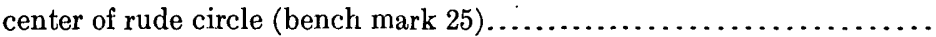

Faith Chapel, on M street, between Four-and-a-half and Sixth streets SW., in southwest corner of top surface of stone doorsill; rude cross (bench mark 30).

Arsenal grounds (old), on stone foundation of the west post of the central or carriage gate; northwest corner of iron plate (bench mark 36 ).........

Seventh-street power house, $P$ street $S W$, on upper surface of corner of foundation stone on west side of western entrance; rude cross (bench mark 41)

Brewery, corner Delaware avenue and $\mathrm{E}$ street $\mathrm{SW}$.; north corner of northern window sill (bench mark 47).

St. Paul's African Methodist Episcopal Church, Eighth street SW., in south corner of south doorsill; rude cross (bench mark 79).................

Kendall Green Baptist Church, on Ninth street, between B and C streets $\mathrm{SW}$., in south end of top stone of south doorstep; rude cross (bench mark 80).

Feet.

29. 721

31.648

275. 822

7.652

39. 111

77.908

Smithsonian Institution, in stone coping of area wall in front of basement window at northeast corner; cross (bench mark 84)..................

Washington Monument grounds, near.Bureau of Engraving and Printing, 25 feet east of board walk at southeast corner of grounds, 150 feet from fence, about 20 feet northeast of a large elm tree (near bridle path), about 120 feet from intersection of bridle path and roadway, about 3 feet below the surface of the ground; brass plus set in a stone which rests on concrete with an iron tube covered by a rough flat stone on the surface

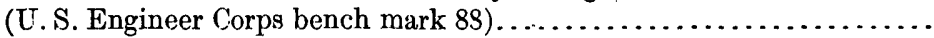

Washington Monument, about 34 meters south of, a few feet outside of the driveway; top surface of an underground obelisk covered with an iron plate (U. S. Engineer Corps bench mark 92)................... 
Washington Monument, at southwest corner of, about 2 inches below the surface of granolithic pavement; top surface of an iron plate (bench mark 93)

Feet.

40. 565

Washington Monument, at southwest corner of, just outside granolithic pavement; top of brass cap over iron rod (bench mark 95$). . . \ldots \ldots \ldots$

Washington Monument, at southeast corner of, just outside granolithic pavement; top of brass cap over iron rod (bench mark 96 )............

Washington Monument, at northeast corner of, just outside granolithic pavement; top of brass cap over iron rod (bench mark 97 )...........

Washington Monument, at northwest corner of, just outside granolithic pavement; top of brass cap over iron rod (bench mark 98 )............

Heurich Brewery, on $\mathrm{C}$ street, between Twenty-fifth and Twenty-sixth streets NW., outer right-hand (east) corner of sill of office door (bench

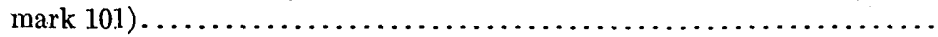

Washington Gas Company's office, on the northwest corner of Twenty-sixth and G streets NW.; outer west corner of the doorsill of south entrance (bench mark 102).

39.572

39.382

39. 501

39.533

22. 149

Easby Point, Engineer's wharf, about 2 feet north of, rude cross cut in sea wall (hench mark 103)

33. 151

4. 549

MARYLAND.

n.?

):

Barclay,. Betterton, Cecilton, Chestertown, Choptank (30'), Crapo, Crisfield, Deal Island, Denton, Dover $\left(30^{\prime}\right)$, Drum Point, Harrington, Hurlock, Nanticoke, Ocean City, Oxford, Pittsville, Princess Anne, Salisbury, Seaford, Snow Hill, St. Michaels, and Tolchester $\left(30^{\prime}\right)$ quadrangles.

CAROLINE, CECIL, DORCHESTER, KENT, QUEEN ANNES, SOMERSET, TALBOT, WICOMICO, AND WORCESTER COUNTIES.

The elevations in the following list are based on heights derived by various gages of the Coast and Geodetic Survey and on checked levels of the Pennsylvania Railroad plus 0.64 foot, a mean correction derived through United States Geological Survey connections. For additional elevations in Dover, Harrington, and Seaford quadrangles see Delaware list (pp. 9, 10); and for Franklin City, Va., in Snow Hill quadrangle, see Virginia list (p. 52).

The leveling was done as follows: Cecilton and Barclay quadrangles, in 1896 by Charles Goldsborough and O. L. Pettibone; Barclay quadrangle, additional work in 1899 by T. D. Leonard and in 1904 by Ralph Hutchins; Betterton, Chestertown, and St. Michaels quadrangles, in 1899 by T. D. Leonard; Hurlock quadrangle, in 1899 by T. D. Leonard, in 1900 by George Bailey, and in 1904 by C. A. Clunet; Seaford quadrangle, in 1899 by T. D. Leonard and in 1904 by C. A. Clunet; Denton and Harrington quadrangles, in 1899 by T. D. Leonard and in 1904 by B. J. Green; Oxford quadrangle, in 1900 by George Bailey and J. W. Hodges, in 1902 by .W. C. Palmer, and in 1904 by C. A. Clunet; Crapo quadrangle; in 1900 by J. W. Hodges and in 1904 by C. A. Clunet; Drum Point quadrangle, in 1904 by C. A. Clunet; Nanticoke quadrangle, in 1900 by J. W. Hodges and in 1902 by W. C. Palmer; Salisbury, Princess Anne, and Pittsville $53492^{\circ}-$ Bull. $434-10-2$ 
quadrangles, in 1900 by J. W. Hodges and C. H. Semper; Crisfield and Deal Island quadrangles, in 1900 by C. H. Semper; Snow Hill and Ocean quadrangles, in 1900 by J. W. Hodges.

$$
\text { CECILTON (DOVER } 30^{\prime} \text { ) QUADRANGLe. }
$$

CHESAPEAKE CITY, SOUTHWEST VIA CAYOTS CORNERS TO EARLEVILLE; THENCE SOUTH AND WEST TO LOCUST GROVE.

Cayots Corners, at road forks; iron post stamped " 83 ".

Feet.

83. 612

Earleville, in stone in front of S. Duhamel's store; bronze tablet stamped " 85 ".

Fredericktown, in face of northwest wing wall of bridge over Sassafras River; bronze tablet stamped " 5 ".

Locust Grove, 40 feet north of crossroads and east side of Beaston's house; iron post stamped " 76 "

LOCUST GROVE, SOUTH TO CHESTERVILLE.

Blacks station, on stone foundation of middle pillar of porch in front of store; highest point.

Chesterville, north corner of crossroads, at corner of brick storehouse; iron post stamped " 55 ".

55.829

MILLINGTON, NORTI ALONG PHILADELPHIA, BALTIMORE AND WASHINGTON RAILROAD AND HIGHWAYS, TO BOHEMIA MILLS.

Millington, northwest corner of Cypress and Sassafras streets; copper plug in doorsill of store, stamped " 26 ".

Massey, southeast corner of foundation of Walsberger's store, northwest corner of crossroads; bronze tablet stamped " 65 ".

Massey, 3.5 miles east of, at Maryland-Delaware state line; top of boundary stone.

Sassafras, dwelling of Mr. Earnest; copper plug in step to back porch, stamped "U.S.G.S. $34 \mathrm{ft}$. B. M.".

BARCLAY (DOVER 30') QUADRANGLE.

CHESTERVILLE, SOUTH TO BENSON CENTER; THENCE EAST TO SUDLERSVILLE; THENCE NORTH TO MILLINGTON.

Benton Corners, 1,000 feet west of, in northeast corner of foundation stone of farmhouse; bronze tablet stamped " 60 ".

60. 911

Barclay, 1.5 miles north of, 50 feet west of railroad crossing, southwest corner of road; top of large stone.

Sudlersville, corner of Church and Main streets, northeast corner of stone foundation; bronze tablet stamped " 66 "

66. 798

BARCLAY, SOUTHWEST TO ROBERTS; THENCE SOUTHEAST TO GOLDSBORO; THENCE NORTHEAST TO MARYDEL.

Roberts, at southeast corner of Scott's store; iron post stamped " 78 ".....

Ingleside, southwest corner of Beatty's yard; iron post stamped " 62 "......

Hollingsworth, south corner of crossroads, outside of corner of garden fence; iron post stamped " 66 "

66.954

63. 548

Goldsboro, on east corner of railroad station; bronze tablet stamped " 63 ".

Marydel, south end of freight house; bronze tablet stamped " 63 " .......

63. 51

CRUMPTON, SOUTHWEST TO M'GINNES.

McGinnes, 2.9 miles southwest of Crumpton, southeast corner of crossroads, 50 feet east of store, in northwest corner of Williams's yard; iron post stamped " 72,1904 " 
SUDLERSVILLE, EAST 4 MILES.

Peters Corners, 3.8 miles east of Sudlersville, northwest corner of crossroads, in base of chimney of private house; aluminum tablet stamped "66, 1904"

Feet.

66. 108

$$
\text { BETTERTON (TOLChESTER 30') QUADRANGLE. }
$$

LOCUST GROVE, WEST TO STILLPOND; THENCE SOUTHWEST TO FA,IRLEE.

Stillpond, at east side of F. H. Harper's store; iron post stamped "BALTO

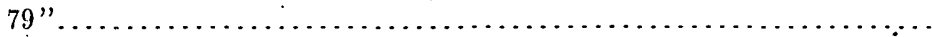
Hanesville, in front of post-office at road to west; iron post stamped " 62 BALTO"

CHESTER'TOWN (TOLCHESTER $30^{\prime}$ ) QUADRANGLe.

FAIRLEE, SOUTHĖAST VIA CHESTERTOWN AND STARKLEY CORNER, TO ROBERTS.

Fairlee, 60 feet east of S. D. Seaverton's boot and shoe shop, in large rock;

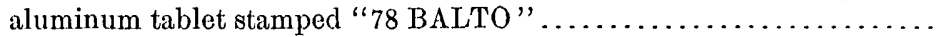
Chestertown court-house; aluminum tablet stamped "22 BALTO "........ Starkley Corner, at northeast corner of crossroads; iron post stamped " 54 BALTO"

FAIRLEE, SOUTII TO EDESVILLE; THENCE SOUTHEAST TO CENTERVILLE; THENCE EAST TO ROBERTS.

Edesville, just south of entrance to store of W. L. Sutton; iron post stamped

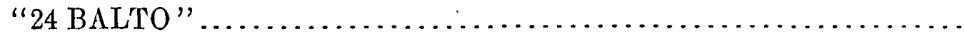

Hadaway's store, northeast of entrance, just under window; iron post stamped "18 BALTO".

Centerville, in southeast corner of court-house yard across path from state survey meridian monument; iron post stamped "60 BALTO"

$$
\text { ST. MichaEls (ChOPTANK 30' } 2 \text { QUADRANGLE. }
$$

CENTERVILLE, SOUTH TO EASTON; THENCE EAST to TANYARD.

Wye Mills, corner of Anthony's store, at the end of piazza; iron post stamped

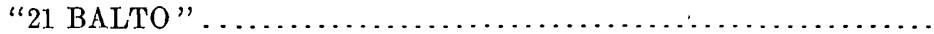

Longwoods, at southeast corner of Callahan's store; iron post stamped " 50 BALTO"

Easton, at south end of second step of court-house; aluminum tablet stamped

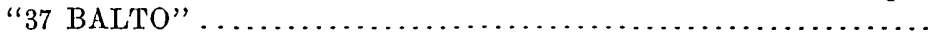

OXFORD (CHOPTANK $30^{\prime}$ ) QUADRANGLE.

EASTON, SOUTH TO TRAPPE.

Trappe, corner Easton road and West street, southeast corner of store of Clarck \& Kirby, in foundation stone; aluminum tablet stamped " 55 "..

AIREYS, NORTHWEST TO CAMBRIDGE; THENCE SOUTHEAST TO BUCKTOWN.

Cambridge, in southwest corner of court-house, about 1 foot above ground; bronze tablet stamped "19 BALTO".........................

SMITIVILLE, NORTHEAST TO MLTON; THENCE SOUTHEAST TO LITTLE BLACKWATER RIVER

Milton (Woolford post-office), north of road opposite road fork to Gum Swamp, in front yard of Baptist Church; iron post stamped "6 ADJ"... 


\section{DENTON QUADRANGLE.}

GOLDSBORO, SOUTHWEST ALONG PENNSYlVANIA RAILROAD TO QUEEN ANNE; THENCE SOUTH ALONG HIGHWAY TO GRIFFIN; THENCE EAST TO HOBBS.

Greensboro, 10 feet north of station, at edge of platform; iron post stamped

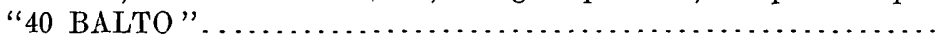

Ridgely, in lawn at northeast corner of Pennsylvania Railroad station, 4 feet from platform; iron post stamped " 69 ADJ 1903 ".............

Hillsboro, at northeast corner of $\mathrm{H}$. Williams's dwelling, on north foundation wall; aluminum tablet stamped " 47 ADJ 1903 "................

Griffin, at northeast corner of yard to W. H. Robinson's dwelling; iron post stamped "42 ADJ 1903 "

Denton, in court-house yard, on top of south meridian post; bronze tablet..

Denton, on southeast corner of court-house; aluminum tablet stamped "43 ADJ 1903 ".

Feet.

40. 817

69. 070

46. 599

41. 376

37. 916

42. 703

HOBBS, SOUTHWEST ALONG HIGHWAY, TO TANYARD.

Williston, 30 feet east of southeast corner of store; iron post stamped " 24

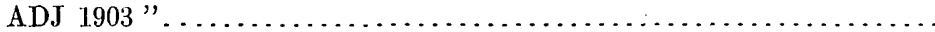

TANYARD, EAST ALONG HigHWAYS TO AMERICAN CORNERS; THENCE NORTU TO HOBBS.

Tanyard, 1.5 miles west of, west end of Dover Bridge, at west end of C. H. Sinclair's house, north of road; iron post stamped " 4 BALTO"......

Newton, 50 feet east of store, at corner of crossroads; iron post stamped " 40 ADJ 1903"

Fowling Creek, in yard to W. H. Collins's dwelling, 50 feet west of M. E. Church; iron post stamped "48 ADJ 1903 ".

American Corners, at crossroads, in corner of field in front of store; iron post stamped "55 ADJ 1903 ".

Concord, 10 feet north of store, at southeast corner of yard to C. E. Todd's dwelling; iron post stamped " 55 ADJ 1903".

Hobbs, in southwest corner of yard to H. C. Hobbs's dwelling, 50 feet northeast of Hobbs station; iron post stamped " 55 ADJ 1903 "............

54. 914

\section{HARRINGTON QUADRANGLE.}

HOBBS, NORTH ALONG HIGHWAYS VIA BURRSVLLE AND WHITELEYSBURG TO GREENSBORO.

Burrsville, 500 feet north of forks of road east, west of street in front of William Outtens's blacksmith shop; iron post stamped "58 ADJ 1903"... Whiteleysburg, at northeast corner of Anthony's store; iron post stamped " "63 BALTO".

HURLOCK QUADRANGLE.

TANYARD, SOUTHEAST TO FEDERALSBURG; THENCE SOUTHWEST TO WILLIAMSBURG; THENCE SOUTH TO RHODESVILLE; THENCE SOUTHWEST TO LINKWOOD.

Linchester, at west side of J. F. Tegar's store; iron post stamped " 18 BALTO"

Federalsburg, at T. O. Jefferson's store; iron post stamped " 10 BALTO".

Linkwood, in grass plat at intersection of roads at station; iron post stamped

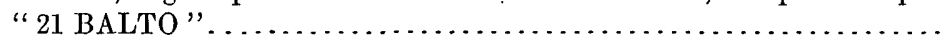

RHODESDALE, SOUTHEAST TO BROOKVIEW; THENCE NORTH TO ELDORADO; THENCE EAST TO GALESTOWN.

Rhodesdale, at northwest corner of post-office; iron post stamped "ADJ $40 "$

Brookview, at southeast corner of W. D. Murphy's store, 300 feet west of Marshyhope Creek; iron post stamped "ADJ 24 "............... 
SEAFORD QUADRANGLE.

GALESTOWN, NORTH VIA OAK GROVE TO FEDERALSBURG.

Reliance, 1 mile south of, on top of Delaware-Maryland state line monument; cross mark.

Feet.

43. 138

Reliance, at northeast corner of crossroads, at southwest corner of Mrs. Phillips's house, opposite former post-office; iron post stamped "45 ADJ".

Oak Grove, 0.25 mile west of, on top of Delaware-Maryland state line

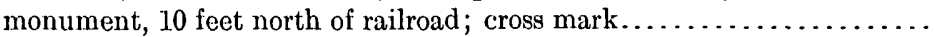

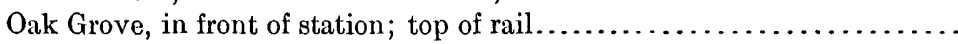

46.4

\section{CRAPO QUADRANGLE.}

BUCKTOWN, SOUTHEAST TO BESTPITCH.

Bucktown, in brick foundation at southwest corner of former post-office; iron post stamped "4 BALTO" ...........................

BUCKTOWN, SOUTHWEST TO GOLDEN HILL.

Bucktown, 4.5 miles west of, at southeast corner of road forks, 7 foet south of letter-box post of W. T. Elzy; iron post stamped "ADJ 7 ".

Gum Swamp, north of road, at wood-road fork north, opposite church and schoolhouse; iron post stamped " $\mathrm{ADJ} 3$ ".

Golden Hill, at road fork at Louis Keene's store; iron post stamped "ADJ $3 "$

GOLDEN HILL, SOUTHEAST TO WINGATE.

Lakesville, 0.5 mile north of, 150 feet south of Nazareth M. E. Church, in northeast corner of schoolhouse foundation; bronze tablet stamped "3

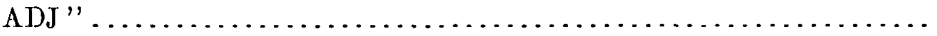

Wingate, at junction of roads 100 yards north of post-office, at southeast corner of road, just outside of fence in front of Mr. Wingate's house; iron

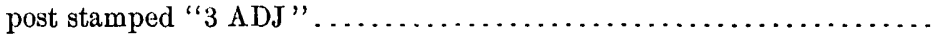

DRUM POINT QUADRANGLE.

GOLDEN HILL, NORTHWEST TO SMITHVILLE.

Smithville, east of road in front of schoolhouse; iron post stamped "6

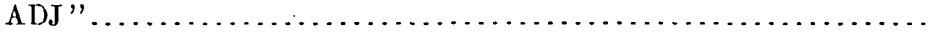

NAN'TICOKE QUADRANGLE.

BESTPITCH, EAST VIA DRAWIBRIDGE TO QUANTICO.

Drawbridge, in brick foundation on south side of small store; bronze tablet stamped "3 BALTO"

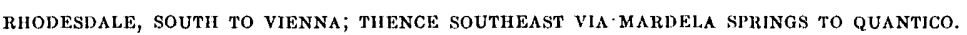

Vienna, in northwest face near north corner of brick house owned in 1.902 by S. G. LeCompte, 60 feet southwest of road; 180 feet northwest of Nanticoke River, in foundation; bronze tablet stamped " 14 "......... Mardela Springs, 15 feet east of post-office building, 30 feet south of road, in grounds of J. L. Langsdale; iron post stamped " 27 "..............

QUANTICO, SOUTH-SOUTHWEST TO WHTHHAVEN; THENCE EAST TO LORETTO.

Whitehaven, southwest side of house owned in 1902 by William Dolby, in brick foundation; bronze tablet stamped " 5 ". 


\section{SALISBURY QUADRANGLE.}

DELMAR, SOUTH ALONG NEW YORK, PHILADELPHIA AND NORFOLK RAILROAD TO LORETTO.

Salisbury, in southwest corner of front face of court-house; aluminum tablet stamped "22 BALTO"...........................

Eden, in northwest corner of foundation of post-office; aluminum tablet stamped "29 BALTO"

Feet.

29.968

EDEN, EAST TO LONGRIDGE.

Longridge, at southeast corner of former post-office; iron post stamped

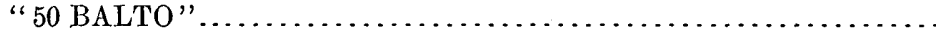

QUANTICO, EAST TO SALISBURY.

Quantico, in corner of fence at Episcopal Church north of Quantico street;

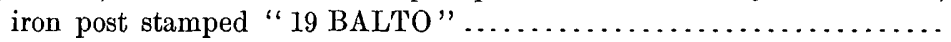

PRINCESS ANNE QUADRANGLE.

LORETTO, SOUTH ALONG NEW YORK, PHILADELPHIA AND NORFOLK RAILROAD TO KINGSTON.

Princess Anne, in front face of Somerset Savings Bank on Main street; bronze tablet stamped " 17 BALTO" ........................

Westover, at intersection of New York, Philadelphia and Norfolk Railroad and road leading to Cottage Grove, opposite M. E. Miles's store; iron post stamped " 15 BALTO" ..................................

LONGRIDGE; SOUTH TO POCOMOKE CITY.

Whiteburg, at southeast corner of old store, inside of J. S. P. White's yard, in front of house; iron post stamped " 30 BALTO"...............

29. 674

WESTOVER, EAST VIA POCOMOKE CITY TO GOODWILL.

Pocomoke City, in doorsill of Pocomoke City Hotel, corner Front and Market streets; aluminum tablet stamped " 8 BALTO"............

DEAL ISLAND QUADRANGLE.

KINGSTON, SOUTHWEST TO HOPEWELL.

Marion, at southeast corner of A. Davis's drug store on Main street, 60 feet east of railroad and 25 feet north of station; iron post stamped " 7 BALTO"

CRISFIELD QUADRANGLE.

AT CRISFIELD.

Crisfield, J. W. Dishatoon's grocery store, face of doorsill; aluminum tablet stamped "5 BALTO 1900 " (elevation determined from Coast

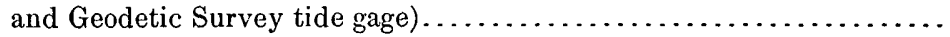

SNOW HILL QUADRANGLE.

ERANKLIN CITY, NORTHWEST TO GOODWILL; THENCE NORTHEAST TO SNOW HILL; THENCE NORTHWEST VIA COLDBOURNE TO LONGRIDGE.

Franklin City, 1 mile north of, on southeast corner of Virginia-Maryland boundary stone, on outskirts of Greenbackville; marked " 7 "..........

Klei Grange, at intersection of roads from Mattaponi Landing and Snow Hill, on property of Drexel heirs, opposite former post-office; iron post stamped "30 BALTO" 
Snow Hill, in sill of front entrañce porch of court-housê, on northeast side Feet.

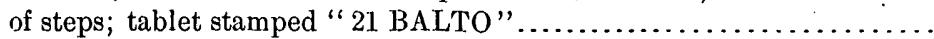

Colbourne, opposite former post-office, in northwest corner of Mr. J. E. Dickerson's front yard; iron post stamped " 40 BALTO "............

40.046

\section{PITTSVILLE QUADRANGLE.}

SNOW HILL, NORTHEAST TO BERLIN.

Newark, at southeast corner of Quenponco station of Philadelphia, Wilmington and Baltimore Railroad; iron post stamped "35 BALTO"....

WANGO, NORTH TO MELSON; THENCE WEST tO DELMAR.

Parsonsburg, at northeast corner of Riggin's grocery store, 100 feet north of road; iron post stamped " $80 "$ "..............................

MELSON EAST VIA TWILLEY to CAMPBELL.

Twilley, in yard at northwest corner of C. W. Lynch's store; iron post stamped "40 BALTO" ..................................

OCEAN CITY QUADRANGLE.

CAMPBELl, SOUTH to berLin; THENCE WEST to WANGO.

Campbell, inside of lot on the northwest intersection of roads, west of F. S. Campbell's store; iron post stamped " 25 BALTO"............

Berlin, on southwest corner of front step of Exchange Savings Bank; bronze tablet stamped " 45 BALTO" ..........................

Belair, Elkton, Havre de Grace, and Parkton quadrangles.

BALTIMORE, CECIL, AND HARFORD COUNTIES.

The elevations in the following list are based on an aluminum tablet in the City Hall Building at Baltimore stamped " 21 ," the height of which is accepted as 20.630 feet above mean sea level, as published in Bulletin 185. The stated elevation of this bench is as follows: By Baltimore City datum, 21.353; by Pennsylvania Railroad, 19.990; by Baltimore and Ohio precise levels, uncorrected, 20.939 ; by Baltimore and Ohio levels, corrected to 1903 adjustment at Washington, 20.745; and by Baltimore and Ohio levels, corrected to 1907 adjustment at Baltimore, 20.563. The accepted elevation was determined by applying 0.640 foot to Pennsylvania Railroad elevations between Elkton and Baltimore, approximately a mean correction derived from gages at Baltimore and Havre de Grace of the Coast and Geodetic Survey.

The leveling was done as follows: In Elkton quadrangle in 1896 by O. L. Pettibone; in Havre de Grace quadrangle in $\mathbf{1 8 9 9}$ by C. M. Smith; in Belair quadrangle in 1899 by C. M. Smith and George Bailey, and in 1900 by J. W. Hodges; in Parkton quadrangle in 1899 by C. M. Smith and George Bailey, and in 1900 by J. W. Hodges, J. S. B. Daingerfield, and Hargraves Wood. 
ELKTON QUADRANGLE.

BOHEMIA MILLS, NORTH TO ELKTON.

Chesapeake, entrance to George R. Ross's store, in north end of doorsill of hall; bronze tablet stamped " 17 ".

Feet.

Elkton; copper bolt on top of step of south entrance to court-house, marked "U.S.G.S.B.M. 28 ft."

Elkton, in doorsill of railroad station; copper bolt...................

ELKTON, NORTH TO APPLETON; THENCE WEST VIA FAIR HILL $a$ TO CALVERT; THENCE SOUTH VIA ZION AND BAYVIEW $a$ TO NORTHEAST POST-OFFICE; THENCE SOUTHWEST TO CHARLESTOWN.

Strayhorn's mills, 2 miles northwest of Appleton, southeast corner of stone wall, foundation of wagon shed; bronze tablet stamped " 173 ".........

Fairview, 3 miles east of, top of land boundary stone in center of road in

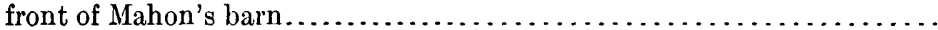

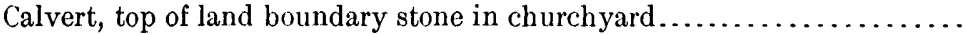

Calvert, in north weste corner John E. Crother's store; bronze tablet stamped "441"

410.50

441. 87

Bayview, southwest corner of crossroads, foundation of W. L. Jones's boarding house; bronze tablet stamped " 385 ".

441. 820

385.388

Bayview, 1.5 miles south of, highest point, on land boundary stone west of road.

Leslie, in front of Baltimore and Ohio Railroad station; top of rail........

Charlestown station, 50 feet north of; copper bolt in northwest corner of northwest cornerstone of cattle guards, stamped " 41 " .............

Charlestown, 390 feet south of railroad station, northeast corner of box culvert, on coping stone; copper bolt (railroad bench mark 50)........

HAVRE DE GRACE QUADRANGLE.

ABERDEEN, NORTHWEST TO CARSINS; THENCE NORTH VIA DARLINGTON to CONOWINGo.

Aberdeen, at east end of box culvert at milepost 65; copper bolt (Philadel. phia, Baltimore and Washington Railroad bench mark 62$) \ldots \ldots \ldots \ldots$.

Aberdeen, in upper foundation stone of First National Bank of Aberdeen, southeast corner; aluminum tablet stamped " 79 BALTO"............

Darlington, 3 miles south of, in east foundation stone of Prospect schoolhouse; bronze tablet stamped "345 BALTO".

Conowingo, southwest bridge seat of county bridge; copper bolt (Philadelphia, Baltimore and Washington Railroad bench mark 11)..........

Conowingo, in foundation stone 2 feet from ground in northwest corner of post-office; aluminum tablet stamped " 76 BALTO"............

80.007

346.213

69.50

77. 334

CONOWINGO, EAST TO RISING SUN; THENCE SOUTH TO PRINCIPIO.

Porter Bridge, in foundation stone 3 feet above ground, in south west corner of J. W. Richards's mill; aluminum tablet stamped " 89 BALTO "....

Rising Sun, in foundation stone, north side of Worthington's store, 1 foot above ground; aluminum tablet stamped " 387 BALTO" ............

PORT DEPOSIT, NORTHEAST VIA PRINCIP̂́IO TO ZION.

Port Deposit, 0.9 mile south of, on northeast bridge seat of bridge 27 ; copper bolt (Pennsylvania Railroad bench mark 3)..................

Port Deposit, in northwest corner foundation stone of Port Deposit postoffice and town hall building; aluminum tablet stamped "16 BALTO".

Principio, in southwest corner of foundation stone of H. R. Lynch's store, 2.5 feet from ground; aluminum tablet stamped " 302 BALTO".......

a Cross lines were run from Bayview via Pleasant Hill to Cowentown, and from Pleasant Hill to Fair Hill; but on these no standard bench marks were set. 
PRINCIPIO, SOUTH TO PRINCIPIO FURNACE; THENCE SOUTHWEST TO HAVRE DE GRACE.

Principio Furnace, 0.7 mile west of post-office, stone monument east of road at southwest corner of property owned by W. H. Currier; marked on fence post at monument 211 .............................

Principio station, Philadelphia, Baltimore and Washington Railroad, in doorsill; copper bolt (railroad bench mark 53)...................

Havre de Grace, in southwest back wall of Susquehanna River Bridge; copper bolt (Philadelphia, Baltimore and Washington Railroad bench mark 57).

Havre de Grace, in southwest corner of Philadelphia, Baltimore and Washington Railroad station, about 8 feet above tracks; aluminum tablet

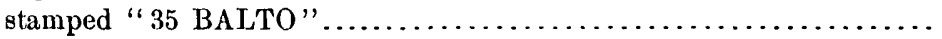

Feet.

21.2. 07

67.400

28. 86

35.730

BELAIR QUADRANGLE.

DARLINGTON, WEST TO SCARBORO; THENCE SOUTH TO FOUNTAIN GREEN.

Allibone (Sandy Hook), 0.5 mile north of, in southeast corner of Mrs. Webster's spring house, 3 feet above ground; aluminum tablet stamped

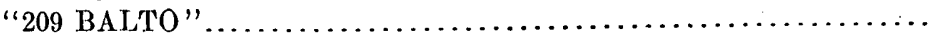

Belair, in steps of court-house; aluminum tablet stamped "394 BALTO" (Elevation by a spur west from Fountain Green).

395.650

BRADENBAUGH ALONG HIGHWAY SOUTHEAST TO FEDERAL HILL: THENCE NORTHEAST TO NEAR WHITEFORD; THENCE SOUTHEAST VIA MACTON TO SCARBORO.

Federal Fill, in southeast corner of foundation stone of J. F. Devoe's house opposite former post-office; aluminum tablet stamped "590 BALTO".

Pylesville, in foundation stone at northeast corner of Pyles's mill, about 4 feet above ground; aluminum tablet stamped " 356 BALTO".......

Macton, 0.1 mile south of, in foundation stone at northwest corner of J. M. McNabb's house, 4 feet above ground; aluminum tablet stamped " 249

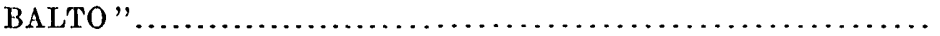

TAYLOR, EAST ALONG HighWA via HIGH POINT, TO HICKORY.

High Point, in foundation stone on north side of High Point schoolhouse; aluminum tablet stamped " 536 BALTO"....................

PARKTON QUADRANGLE.

BENTLEy, EAST aLONG highWAY, to bRADENBaUgh.

Bentley, 1,300 feet south of, in northwest wing wall of bridge 53; copper bolt (Pennsylvania Railroad bench mark 33 )...................

Bentley, 0.5 mile north of, in northwest corner of Bentley Methodist Church; bronze tablet stamped "607 BALTO" (reported out of place December 11, 1907)

Trump, in north foundation of M. S. Van Trump's store, at edge of cellar; bronze tablet stamped " 716 BALTO" ........................

Shane, north west corner of schoolhouse lot; stone marked " 709 ".........

Bradenbaugh, in stone foundation of former post-office, just to right of cellar entrance; bronze tablet stamped "BALTO 604 ".............

SPARKS, EAST ALONG HIGHWAY, TO TAYLOR.

Sparks (Philopolis), 0.1 mile east of station, in southwest corner of Union Chapel, I foot above ground; bronze tablet stamped "BALTO 268 "....

Taylor, in southwest corner of S. Phelps's blacksmith shop, about 2 feet. above ground; bronze tablet stamped " 583 BALTO".............
591.477

357.778

536.864

502. 110

608. 019

716. 333

709. 26

605. 149 
MONKTON, WEST TO MOUNT CARMEL AND RETURN.

Monkton, 0.5 mile north of, in center of east end of railroad box culvert; Feet.

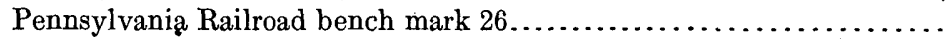

Mount Carmel, in foundation stone of porch of northeast corner of Miller's store and post-office; bronze tablet stamped "674 BALTO "..........

SPARKS, NORTH TO BENTLEY.a

Whitehall, in northwest corner of post-office, 2 feet above ground; bronze tablet stamped " 348 BALTO".

Annapolis, Baltimore, Ellicott, Laurel, Relay, and Westminister quadrangles.

ANNE ARUNDEL, BaLTIMORE, CARROLL, AND PRINCE GEORGES COUNTIES.

The elevations in the following list are based on an aluminum tablet in the City Hall, Baltimore, Md., the height of which is accepted as 20.630 feet above mean sea level (see previous list, p. 21). The leveling extends from various bench marks of the Baltimore and Ohio and the Pennsylvania Railroad companies in the vicinity, a correction of 0.2 foot having been subtracted from the Baltimore and Ohio Railroad elevations and 0.640 foot added to the Pennsylvania Railroad elevations.

The leveling was done as follows: In Annapolis, Baltimore, Ellicott, and Westminster quadrangles in 1902 by W. C. Palmer and W. G. Coates; in the Laurel and Relay quadrangles in 1904 and 1905 by J. W. Hodges and Ralph Hutchins; and in the Laurel quadrangle in 1906 by. G. S. Buckley.

BALTIMORE QUADRANGLE.

AT Catonsville.

Catonsville, State Insane Asylum, east face of southeast wing; bronze tablet stamped " 396 BALTO".

Feet. 395.954

AT PIKesville.

Pikesville, main building of Soldiers' Home, just east of main entrance, in southwest corner of foundation wall; bronze tablet stamped " 516 BALTO". 516.078

SHERWOOD, EAST ALONG HIGHWAYS VIA TOWSON TO A PONT 4.6 MILES EAST; THENCE VIA LAVENDER HILL (PARKVILLE) TO LAURAVILLE.

Sherwood, 100 feet south of station, in west end of east center of arch culvert; copper bolt (Pennsylvania Railroad bench mark)..............

Towson, on southeast cornerstone of court-house porch; bronze tablet

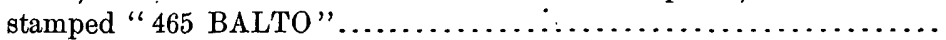

Parkville, Kelchensten's store and post-office, northeast corner of foundation wall; bronze tablet stamped " 343 BALTO".................

Lauraville, near northeast corner of city boundary, J. C. Mann's wagon shop, on south end of doorsill; chiseled square.....................
284.269

465. 371

343.438

189.00

a Set from Pennsylvania Railroad elevations plus 0.64 foot. 
TIMONIUM, EAST ALONG HIGHWAYS TO BOSLEY; THENCE SOUTHWEST TO TOWSON.

Timonium, 0.5 mile south of, 800 feet north of milepost 11, in west end of culvert; copper bolt (Pennsylvania Railroad bench mark 14).

Feet.

Bosley, on southeast corner of Valley Hotel; bronze tablet stamped " 223 BALTO"

$\Lambda T$ MOUNT WASHINGTON.

Mount Washington, bridge 5, over Western Run, at northeast side on bridge seat; bronze tablet stamped "198 BALTIMORE $1900 " . . . . . .$.

0.4 MLE NORTH OF REISTERTOWN, EAST ALONG HIGHWAYS VIA SHAWAN, TO COCKEYSVILLE.

Shawan, F. G. Wheeler's store and private residence, on southeast corner of foundation wall; bronze tablet stamped " 439 BALTO"............

Cockeysville, 150 feet southeast of signal station, on northeast corner of culvert; copper bolt (Pennsylvania Railroad bench mark 17)............

278.838

PRECISE-LEVEL LINE OF BALTIMORE AND OHIO RAILROAD.

Landsdowne, east of, in large coping stone of retaining wall west end of north abutment to overhead bridge; copper bolt (bench mark 35$). . . . .$.

West Baltimore, vertical rail section between tracks at station; bench

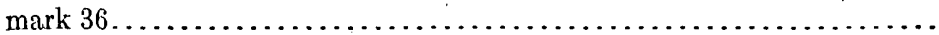

Mount Winans, vertical rail section between tracks; bench mark $37 \ldots . .$.

Mount Winans, 0.5 mile east of, south tie stone west abutment bridge 3-A; copper bolt (bench mark 38 ).

Baltimore, near corner West Ostend and Sharp streets, in middle of south coping of small culvert; copper bolt (bench mark 39) .

Camden, in offset of wall for elevated tracks, about 300 feet from west end

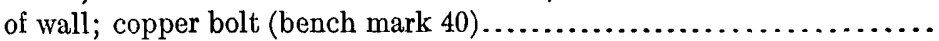

Baltimore, corner Howard street and Fifth avenue; city elevation 127.851 (1288).

127. 237

Mount Royal, in coping of retaining wall north of track, about 75 feet from end of tunnel; copper bolt (bench mark 41)......................

Mount Royal, 0.5 mile east of station, south end of east abutment of bridge over Pennsylvania Railroad (bench mark 42 )......................

Milepost "Baltimore 3 miles," about 400 feet west of, south end of west abutment of small bridge; copper bolt (bench mark 43)..............

Telegraph pole $92-8$, in north end of bridge seat of east abutment of large iron bridge; copper bolt (bench mark 44) .....................

Gay street, on bridge seat south side of tracks west abutment of bridge at

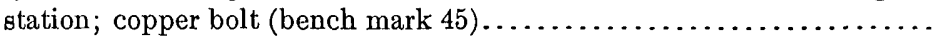

Duncans Lane Bridge, between tracks on bridge seat of west abutment, opposite telegraph pole $90-11$; copper bolt (bench mark 46$) . \ldots \ldots \ldots .$.

Bay View, bridge over Philadelphia road, north end of bridge seat of east abutment, 100 feet west of telegraph pole 89-20; copper bolt (bench

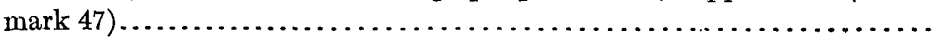

Herring Run, in east abutment bridge $3 \mathrm{~B}$, at telegraph pole 88-13; copper

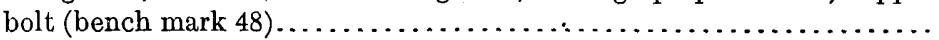

Rosedale, between tracks opposite milepost B 9 ; vertical rail section (bench

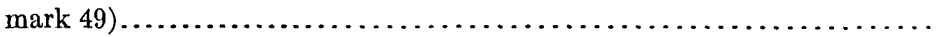

Milepost "Balto. 10 miles," between tracks; vertical rail section (bench

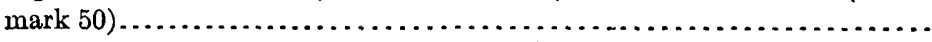

149. 546

133. 566

1.50 .615

108. 688

30.450

58. 600 


\section{ELLICOTT QUADRANGLE.}

ELLICOTT CITY, ALONG BALTIMORE AND OHIO RAILROAD AND HIGHWAYS, VIA HOLLOFIELD AND ROCKDALE, TO PIKESVILLE.

Ellicott City, southwest corner of court-house (south face); aluminum tablet stamped "233 BALTO".

Feet.

233. 412

Oella, at W. J. Dickey \& Son's woolen mills, west of tracks, south bridge abutment of Baltimore and Ohio Railroad bridge over Patapsco River; chisel mark.

Oella, 1.6 miles northwest of; copper bolt on southeast corner of west wing wall of Union dam, stamped " 187 ".

Hollofield, 1.1 miles northwest of, public school No. 2, on Quaker Hill, on southwest corner of stone doorsill; chiseled shelf....................

456.47

ROCKDALE, WEST ALONG HIGHWAYS, TO WOODSTOCK; THENCE NORTH TO REISTERSTOWN.

Woodstock College, on west side of main entrance, over small window, on center stone; aluminum tablet stamped " 415 BALTO"...............

Reisterstown, northwest corner stone of Russel's store; aluminum tablet stamped "735 BALTO"

735.458

WOODSTOCK, SOUTHWEST ALONG HIGHWAYS, TO WEST FRIENDSHIP; THENCE NORTH VIA SYKESVILLE TO GAMBER; THENCE EAST TO A POINT 3.8 MILES SOUTH OF REISTERSTOWN.

West Friendship, just west of post-office, on milestone 19 north of Frederick pike; bronze tablet stamped "476 BALTO".

476. 193

Sykesville, in second step of Sykesville Bank; bronze tablet stamped "383 BALTO"

Gamber, on southeast corner of Mount Pleasant M. E. Church; bronze tablet stamped "606 BALTO"

PRECISE-LEVEL LINE OF BALTIMORE AND OHIO RAILROAD

Ilchester, 0.25 mile west of Orange Grove station, in native rock north side of tracks, 250 feet west of milepost "12 miles;" copper bolt (bench mark 103)

95. 158

Ilchester, between tracks in mud wall west of abutment bridge of Ilchester tunnel; copper bolt (bench mark 104)

Grays, between tracks opposite milepost "Balto. 14 miles," on old line at station; vertical rail section (bench mark 105)....................

Ellicott City, in native rock at south side of tracks, about 600 feet west of station; copper bolt (bench mark 106).

Oella, in center north coping of arch culvert about 400 feet east of station;

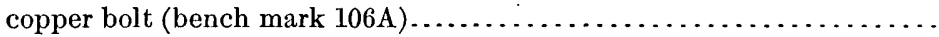

Oella, 0.75 mile west of, in native rock at south side of tracks, 40 feet east of telegraph pole 16-10; copper bolt (bench mark 107)................

Union dam, in southeast corner of west wing wall; copper bolt (bench mark 108)

Union dam near bench mark No. 108; "U.S.G.S." on.................

Milepost "Baltimore 18 miles," 125 feet west of, 6 feet from east end of north coping of culvert; copper bolt (bench mark 109).

144.546

148. 205

168. 607

187. 704

187. 779

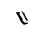

192. 793

Hollofield, in west end of north coping of culvert near target at tower; co..per bolt (bench mark 110)

200. 166

Alberton, 0.75 mile west of Hollofield, in rock at south side of tracks, telegraph pole 19-34; copper bolt (bench mark 111).................. 
Alberton, 0.2 mile west of, between tracks at west abutment of bridge 17; copper bolt (bench mark 112).

Dorseys Run, in center of south coping of arch culvert; copper bolt (bench mark 113).

Dorseys Run, $\frac{3}{8}$ mile west of, in center of north coping of arch culvert 21; copper bolt (bench mark 114)................................

Dorseys Run, 1 mile west of, in center of north coping of arch culvert 22; copper bolt (bench mark 115).

237.222

244. 994

Davis, in center of south coping of arch culvert 23; copper bolt (bench mark 116).

249.574

Woodstock, 500 feet east of station, in south end of abutment of small culvert; copper bolt (bench mark 117).

Milepost "Balto. 26 miles," between tracks at; vertical rail section (bench mark 118)

Telegraph pole $26-28,20$ feet west of, in retaining wall at north side of tracks; copper bolt (bench mark 119)

Marriottsville, in north end of west mud wall of bridge 25 ; copper bolt (bench mark 120).

Henrytown tunnel, 300 feet east of, bridge seat west abutment of bridge 26 ; copper bolt between tracks (bench mark 121)

Milepost "Balto. 29 miles," 100 feet west of, in north end of small box culvert; copper bolt (bench mark 122) . .........................

Gorsuch, in north end of west abutment of culvert 27, at station; copper bolt (bench mark 123)

Sykesville, between tracks, opposite milepost "Balto. 31 miles;" vertical rail section (bench mark 124).

Gaither, between tracks in bridge seat of bridge at west end of Sykesville tunnel; copper bolt (bench mark 125).

Gaither, 0.25 mile west of, in north end of west abutment of bridge 28; copper bolt (bench mark 127).

271.734

288. 391

291.769

293. 010

299. 329

311. 115

323.806

351.240

408. 947

419.402

WESTMINSTER QUADRANGLE.

REISTERSTOWN, NORTH ALONG HIGHWAYS VIA WOODENSBURG AND FOWBLESBURG TO HAMPSTEAD; THENCE EAST TO MOUNT CARMEL.

Woodensburg, northeast corner of Methodist church; top of corner stone marked "A.D. 1888"

Fowblesburg station, Argile's store and post-office, in east foundation wall at center of building; bronze tablet stamped "703 BALTO"...........

Hampstead, private residence owned by C. W. Murray, in southwest corner of foundation wall; bronze tablet stamped "91.3 BALTO"...........

913.471

HAMPSTEAD, ALONG HighWAYS TO MELROSE; THENCE EAST TO ROCKDALE; THENCE SOUTH TO MOUNT CARMEL.

Manchester, 0.5 mile northwest of, just over center of stone culvert at first stream to right; square cut on stone.

857.57

Rockdale, on northwest corner of paper mill; bronze tablet stamped " 510 BALTO"

WOODENSBURG, SOUTHWEST ALONG HIGHWATS, TO FINKSBURG; THENCE NORTHWEST TO WESTMINSTER.

Westminster, on fifth step of main entrance to court-house; bronze tablet stamped "774 BALTO".................................. 


\section{ANNAPOLIS QUADRANGLE.}

\section{AT ANNAPOLIS. $a$}

Annapolis, at Naval Academy, 8 feet southwest of Observatory building; top of stone pier (Coast and Geodetic Survey bench mark "OBS").. Annapolis, corner of State House; aluminum tablet stamped "58 BALTO"

Feet.

23. 012

57.546

\section{RELAY QUADRANGLE.}

AT WINANS.

Winans, 780 feet south of Pennsylvania Railroad bench mark No. 101, east side of Baltimore and Ohio Railroad bridge......................

RELAY, EAST ALONG HIGHWAY TO PUMPHREY; THENCE ALONG MARYLAND ELECTRIC RAILWAY TO ELVATON; THENCE SOUTHWEST ALONG HIGHWAY TO BOWIE.

Relay, on Baltimore and Ohio Railroad viaduct, northeast face of northeast abutment; bronze tablet stamped "71 BALTO"

Pumphrey, in center of north foundation wall of station and store build-

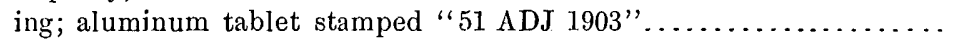

Glenburnie, 1.5 miles northeast of, on top of northwest retaining wall of highway bridge over Furnace Branch; aluminum tablet stamped " 8

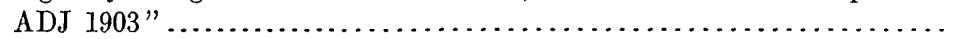

Glenburnie, on northwëst abutment of Furnace Branch bridge; cut (Mary-

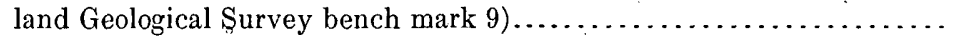

Elvaton, in corner of dwelling 50 feet west of store; copper nail (Maryland

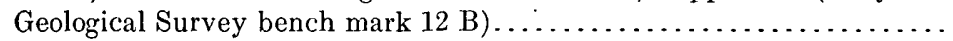

Elvaton post-office, 100 feet south of station, in north foundation of water tank; aluminum tablet stamped "69 ADJ 1903" .................

Benfield, in southeast foundation wall of D. L. Stone's house; aluminum tablet stamped "110 ADJ 1903 ".

Waterbury, 0.5 mile north of, in east wall of railway bridge over highway; aluminum tablet stamped "92 ADJ 1903 ".

Conaways, 0.3 mile northwest of, in southeast abutment wing wall of highway bridge over Little Patuxent River; aluminum tablet stamped "53 ADJ 1903".

Conaways, 4 miles northwest of, south abutment of Philadelphia, Baltimore and Washington Railroad bridge over Little Patuxent River; cop-

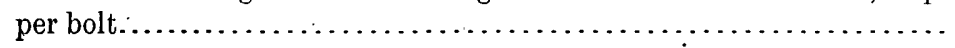

at JONES Station, ON MARYLAND ELECTRIC RAILWAY. $b$

Jones, in southeast corner of foundation of Mr. Jones's warehouse; alumi-

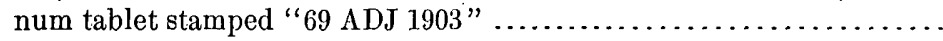

AT ODENTON AND SEVERN STATIONS, ON PHILADELPHIA, BALTIMORE AND WASHINGTON RAILROAD.

Odenton, inside yard at station, northwest corner; iron post stamped " 160 ADJ 1903" .

Severn, 20 yards east of station, 410 feet south of milepost 110, east of track; iron post stamped "167 ADJ 1903".

166. 960

$a$ Coast and Geodetic Survey bench mark "Woods" was checked by two independent lines from bench mark "OBS" and appears to have settled 0.34 foot; the doorstep was badly out of plumb.

$\checkmark$ Set from adjusted Maryland State Geological.Survey levels. 
Dorsey, east of railroad, south of highway, in west foundation wall, northwest corner of store; aluminum tablet stamped "121 ADJ 1903"

PRECISE-LEVEL LINE OF BALTIMORE AND OHIO RAILROAD.

Dorsey, between tracks opposite milepost "Balto.. 14;" vertical rail section (bench mark 26).

Harwood, 400 feet west of milepost "Balto. 13 miles," west end north coping of culvert; copper bolt (bench mark 27$) \ldots \ldots \ldots \ldots \ldots \ldots \ldots \ldots \ldots$

Hanover, 450 feet east of milepost "Balto. 12 miles," at middle of south coping of arch culvert abutment; copper bolt (bench mark 28).........

Milepost "Balto. 11 miles," between tracks opposite; vertical rail section (bench mark 29).

Elk Ridge, 30 feet west of milepost "Balto. 10," in coping of retaining wall

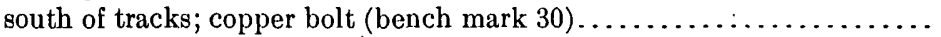

Relay (St. Denis), in center of stone post at east end of Viaduct Branch, south of tracks at Relay; copper bolt (bench mark 31 )...............

St. Denis, 0.1 mile east of, at middle of south coping of arch culvert; copper

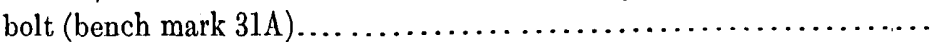

Halethorpe, 0.3 mile east of St. Denis, in first course of stone at east end of north abutment road crossing; copper bolt (bench mark 32 )...........

Telegraph pole 5-20, south end of west wall of culvert; copper bolt (bench mark 33).

Landsdowne, elevation given by Pennsylvania Railroad, $36.15 \ldots \ldots \ldots$.

Landsdowne, opposite milepost "Balto. 4 miles;" vertical rail section (bench mark 34).

Avalon, 0.5 mile west of Relay station, northwest corner culvert; copper bolt (bench mark 100)...................................

Vineyard, at east end of south coping of bridge 10; copper bolt (bench mark 101).

Orange Grove, in east end of west offset of south coping of bridge 11; copper

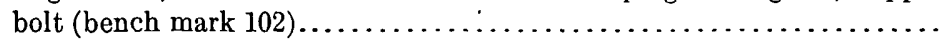

LAUREL QUADRANGLE.

AT BOWIE.

Bowie, in south foundation wall of Imperial Hotel; aluminum tablet stamped " 154 ADJ 1903" ..................................

Bowie, on stone east of tower east of Philadelphia, Washington and Baltimore Railroad track; copper bolt............................

148. 658

BALTIMORE AND OHIO RAILROAD PRECISE LINE.

Laurel, on southwest corner of Main street and Washington avenue, in east face at northeast corner of large brick store building, 3 feet above ground; aluminum tablet stamped "156 ADJ 1903"

Waterloo, at northeast corner of crossroads, in southeast corner of south foundation wall of house; aluminum tablet stamped "232 ADJ 1903"..

$\Lambda$ nnapolis Junction, in east foundation wall of north abutment of overhead bridge; copper bolt.

Annapolis Junction, in southeast face of central brick foundation pier of warehouse of Alphonso Latchford; aluminum tablet stamped "171 ADJ".

170.869

a Set in 1905 and $r \in$ zhecked in 1906 from adjusted elevation of the Baltimore and Ohlo Rallroad preclse line.

$\checkmark$ Bench marks set in 1905 and rechecked in 1906. 
ELLICOTT CITY, SOUTHWEST ALONG HIGHWAY, TO CLARKSVILLE.

Columbia, in south foundation wall of post-office building; aluminum tablet stamped "402 ADJ 1904 "

Feet.

Elioak, in southeast corner of foundation wall of store and post-office; aluminum tablet stamped " 433 ADJ 1904 ".

402. 548

Clarksville, in southeast corner of stone building, store and post-office, 2 feet above ground; aluminum tablet stamped "487 ADJ 1904" .......

486. 870

AMMENDALE, WEST ALONG HIGHWAY, TO FAIRLAND; THENCE NORTH TO BURTONSVILLE; THENCE NORTHWEST TO ASHTON; THENCE NORTHEAST TO CLARKSVILLE.

Ammendale, between Baltimore and Ohio railroad tracks, opposite milepost "Baltimore 26 miles;" vertical rail section

137. 910

Ammendale, in southeast corner of Lasalle Academy building; aluminum tablet stamped " 182 ".

182. 040

Ammendale, 3.2 miles northwest of, at main crossroads in woods, 15 feet east of roads; iron post stamped " 279 "

279. 018

Fairland, 50 feet east of road, southwest corner of frame house, in foundation; aluminum tablet stamped " 414 ".

Burtonsville, 0.3 mile northwest of, northwest corner of Liberty Grove Church; aluminum tablet stamped " 482 ".

Spencerville, 0.1 mile west of, 60 feet south of road, 2 feet from northeast corner of house, in stone; aluminum tablet stamped " 516 B"..........

Ashton, 2.4 miles northeast of, Snell Bridge over Patuxent River, at south end of west abutment, in bridge seat; aluminum tablet stamped" "294".

PRECISE-LEVEL LINE OF baLtimore AND OHO RAILROAD.

Berwyn, 0.25 mile west of, in north end of bridge seat of east abatment of small bridge, telegraph pole $30-17$; copper bolt (bench mark $9 \mathrm{~A}$ ).......

Branchville, 0.24 mile east of, at west end of south coping of box culvert, telegraph pole 20-24; copper bolt (bench mark 10).................

Milepost 29B, between tracks opposite; vertical rail section (bench mark 11)

Sunnyside, 0.5 mile east of, in south coping of culvert, telegraph pole;

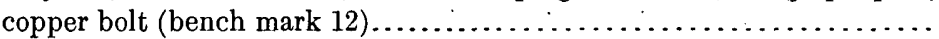

Beltsville, 0.6 mile east of, north end of bridge seat, east abutment of bridge, telegraph pole 26-20; copper bolt (bench mark 13).

65. 730

77. 598

Milepost "Balto. 26 miles," between tracks opposite; vertical rail section (bench mark 14).

137. 910

Telegraph pole 25-7, middle of south coping of culvert opposite; copper bolt (bench mark 14A).

Muirkirk, at west end of foundation of south abutment to overhead bridge;

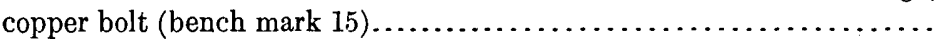

Contee, opposite milepost "Baltimore 24 miles;" vertical rail section be-

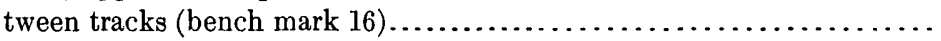

Telegraph pole 23-11, at north end of bridge seat at east abutment of bridge; copper bolt (bench mark 17)...............................

Mistletoe Springs, center of south coping of culvert, at telegraph pole 22-24;

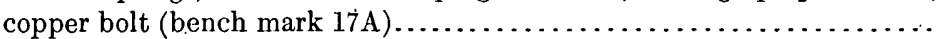

Telegraph pole 21-30, in south end of east abutment of bridge; copper bolt

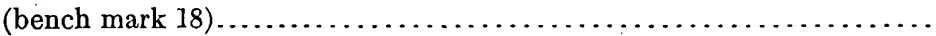

Laurel, in south end of bridge seat at east abutment of bridge 6; copper bolt (bench mark 19)..........................................

Savage, between tracks opposite milepost "Balto. 20 miles;" vertical rail

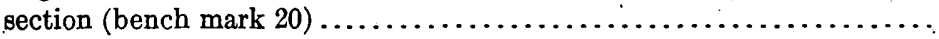

176. 008

169. 774

155. 212

149. 314

173. 002 
- Annapolis Junction, at telegraph pole $19-18$, in south end of east abutment of bridge 5; copper bolt (bench mark 21).

Feet.

154. 412

Annapolis Junction, in east end of foundation of north abutment of overhead bridge; copper bolt (bench mark 22).

Milepost "Balto. 17 miles," between tracks opposite; vertical rail section (bench mark 23).

Jessup, 0.1 mile east of Bridewell, west end of north coping of arch front of south building; copper bolt (bench mark 24). ..

Montevideo, opposite milepost "Balto. 15 miles;" vertical rail section (bench mark 25).

158. 454

Ijamsville, Mount Airy, Rockville, and Seneca quadrangles.

FREDERICK, HOWARD, AND MONTGOMERY COUNTIES.

The elevations in the following list are based on the Baltimore and Ohio precise levels corrected by subtracting 0.2 foot, to agree approximately with the 1903 adjustment at Washington. Many of the Baltimore and Ohio Railroad bench marks in this area are included.

The leveling in Ijamsville, Mount Airy, and Seneca quadrangles was done in 1906 by R. A. Farmer; in Rockville quadrangle partly in 1904 by Ralph Hutchins and partly in 1906 by T. A. Green and W. O. Tufts.

$$
\text { MOUNT A:IRY QUADRANGLE. }
$$

CEDAR GROVE, NORTHEAST ALONG HIGHWAY, TO MOUNT AIRY.

Damascus, Dr. B. F. Lansdale's house, southeast corner of foundation; tablet stamped " 845 "

Jieet.

Ridgeville, Nelson's Hotel, southeast corner of coping of yard; tablet stamped " 817 "

845.802

817. 264

MOUNT AIRY, NORTHWEST ALONG HIGHWAY, TO CROSSROADS 1 MILE NORTIL OF NEW LONDON; THENCE NORTH TO IIBERTYTOWN; THENCE EAST TO WINFIELD; THENCE SOUTH TO WOODBINE.

Libertytown, Mrs. Carter's house, northeast corner of foundation; tablèt stamped " 523 ".

Unionvilie schoolhouse, 8 feet east of main entrance, in stone foundation; tablet stamped "450 MARYLAND".

450. 200

Taylorsville, 1.5 miles west of, in south wall of Franklin schoolhouse;

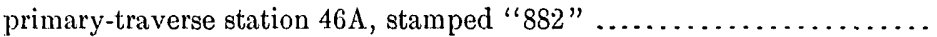

Taylorsville schoolhouse, at northeast corner, in foundation; aluminum tablet stamped " 819 "

882.952

819. 693

Day, in east foundation of church, at southeast corner; tablet stamped "768"

Woodbine, at milepost 37; vertical rail section (Baltimore and Ohio Railroad bench mark 131, elevation, 486.338)

.491 .146

Woodbine, 1.5 miles east of, at milepost 36 ; vertical rail (Baltimore and Ohio Railroad bench mark 130).

WOODBINE, SOUTH ALONG BIGIIWAY, TO UNITY.

Lisbon, at southwest corner of Mr. Lascey's house; on east side of wagon road, in foundation; tablet stamped " $591 "$ "....................

Florence, northeast ccrner of store, in foundation; tablet stamped " 627 ". . $53492^{\circ}-$ Bull. $434-10-3$ 
PRECISE-LEVEL LINE OF BALTIMORE AND OHIO RAILROAD.

Hoods Mills, 100 feet west of milepost "Balto. 34 miles," at south end of small culvert; copper bolt (bench mark 128)...................

Hoods Mills, in large rock south side of track at dam; copper bolt (bench mark 129)

Woodbine, about 300 feet west of station, in northeast corner of culvert; copper bolt (bench mark 131A)

Feet.

428. 266

442.005

496.039

Mount Airy, at east end of cut-off, between tracks in bridge seat of east abutment of bridge; copper bolt (bench mark 133).

550.680

Watersville, 0.25 mile west of, in north coping of culvert abutment, on Mount Airy cut-off; copper bolt (bench mark 134).

Mount Airy cut-off, in west end of south coping of culvert at east end of cut; copper bolt (bench mark 135).

622.228

Mount Airy tunnel, 0.5 mile west of, east end south coping of culvert; cop-

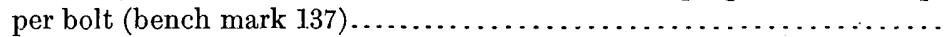

Plane No. 4, 250 feet east of, in east end of north coping arch; copper bolt

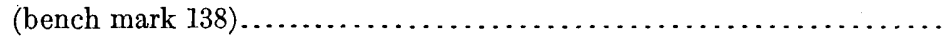

Bartholows, 500 feet west of milepost "Balto. 47 miles," in east end of small culvert south of tracks; copper bolt (bench mark 139)...............

Bartholows, 300 feet west of, in west end of north coping of arch road cross-

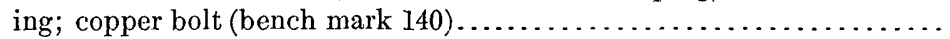

Small culvert, in north end of, about 400 feet west of crossing of old and new tracks; copper bolt (bench mark 141) .....................

550. 317

528.570

489.661

IJAMSVILLE QUADRANGLE.

CLARKSBURG, NORTHWEST TO FREDERICK JUNCTION.

Hyattstown, south abutment of bridge over Little Bennetts Creek, southeast corner of bridge seat; tablet stamped " 362 ".

361.950

Urbana, at west wall near northwest corner of former post-office; tablet stamped " 468 ".

467.831

Frederick Junction, highway bridge over Monocacy River, southwest corner of south abutment, in southwest coping stone; tablet stamped " 253 ".

Frederick Junction, Baltimore and Ohio Railroad bridge over Monocacy River, east abutment, northeast mud wall; copper bolt.............

266.313

FREDERICK JUNCTION, NORTH TO CHARLESVILLE; THENCE EAST VIA WALKERSVILLE AND MOUNT PLEASANT TO LIBERTYTOWN.

Frederick, 300 feet east of station, about 15 feet south of track, in natural rock; copper nail (Baltimore and Ohio Railroad precise-level mark)....

Frederick, south side of Church street, between North Market and Court streets, Jacob Rohrback's residence and office, stoop to office, top step, southwest corner; tablet stamped " $296 "$ ".......................

Charlesville, bridge over Tuscarora Creek, southwest coping stone of south

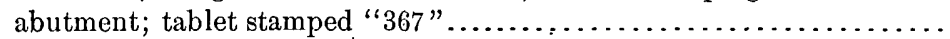

Walkersville, 2 miles west of, north end of center pier of bridge over Monocacy River, primary-traverse station 547; tablet stamped " 283 "..

Walkersville, Walkersville Savings Bank, in front wall, 2 feet below window sill; tablet stamped " 320 ".

289.464

295.835

366. 875

283.101

319.834

Mount Pleasant, Clayton Zimmerman's brick store, 2 feet below window sill; tablet stamped " 475 ".

Libertytown, 2.5 miles southwest of, crossroads at Chestnut Grove School No. 5 , south foundation wall near west corner of schoolhouse, 0.5 foot

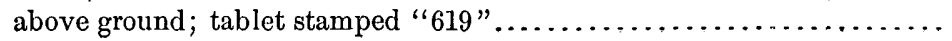


AT CROSSROADS 1.2 MILES NORTH OF NEW LONDON.

New London, 1.2 miles north of, at northwest corner of road crossing on Libertytown pike, in flint rock 1 by 2 by 3 feet; aluminum tablet stamped

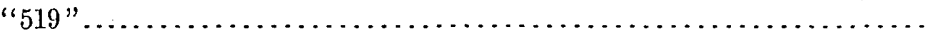

Monrovia, 300 feet west of, precise-level line of Baltimore and Ohio Rail. road between tracks at east bridge seat; copper bolt (bench mark 143)..

Milepost "Balto. 51 miles," 40 feet east of, in north end of east bridge seat; copper bolt (bench mark 144) ................................

Telegraph pole 51-23, at center of north coping of arch culvert; copper bolt (bench mark 145).

51.9. 120

427.422

391. 1.91

377.312

Telegraph pole 52-19, 20 feet east of, at north end of small culvert; copper bolt (bench mark 146)..................................

Milepost "Balto. 54 miles," between tracks at east bridge seat; copper bolt (bench mark 148).

360.284

329.728

Ijamsville tunnel, at west end of, between tracks in west bridge seat of new bridge; copper bolt (bench mark 149)

Reels Mill, 1 mile east ${ }^{\circ}$ of, between tracks in west bridge seat at bridge; copper bolt (bench mark 150)...............................

Reels Mill, in foundation stone southwest corner of coal chute; copper bolt (bench mark 151).

291.. 974

274. 228

Frederick Junction, in north end of mud wall of east abutment of Monocacy River Bridge; copper bolt (bench mark 1.52) ...................

Frederick, about 2.5 miles from, in south end of west coping of culvert; copper bolt (bench mark 152A)

Frederick Station, in rock east of tracks, end of cut abutment halfway to Frederick Junction; copper bolt (bench mark 152B).

266. 313

285. 117

302. 745

Frederick, about 300 feet south of station, in native rock west of tracks; copper bolt (bench mark 152C).

Telegraph pole 58-34, 50 feet east of, in west end south coping of culvert; copper bolt (bench mark 1.53)

Frederick Junction, 1.5 miles west of, in west end of north coping of culvert 36; copper bolt (bench mark 153A).

289.464

252.400

251.41 .0

Buckeystown, in west end of north coping of culvert at Buckeye Station;

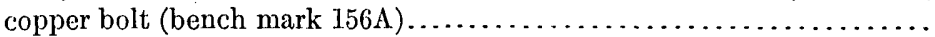

Doubs, about 275 feet west of milepost "Balto. 65 miles," in center of north coping culvert $36 \frac{1}{2}$; copper bolt (bench mark 159).................

ROCKVILLE QUADRANGLE.

ASHTON, WEST TO SANDY SPRING AND RETURN.

Sandy Spring, 30 feet south of road, granite slab at entrance to the office of the Mutual Fire Insurance Company; aluminum tablet stamped "484". .

483.835

ClaRkSVILLE, WEST ALONG HighWAy, TO GERMantown.

Clarksville, 3.9 miles southwest of, north of highway, at Patuxent River, 50 feet west of center of bridge, 2.5 feet from east end of large flat rock; aluminum tablet stamped " 316 ADJ 1904"

Unity, 35 feet west of former post-office, in northeast foundation wall of Ernest Gregg's tenant house, south of highway; aluminum tablet stamped "520 ADJ 1904"

282. 326

285.687 .

Unity, 2.1 miles southwest of, at Hawlings River, in west end of northeast abutment on bridge seat, 1.7 feet below floor surface; aluminum tablet stamped " 457 ADJ 1904" 
Laytonsville, in south foundation wall of store and post-office, at northwest corner of crossroads; aluminum tablet stamped "615 ADJ 1904" .......

Goshen, in southwest corner of foundation wall of store; aluminum tablet stamped "425 ADJ 1904"

Feet.

615.233

Brink, in east foundation wall of W. T. Dowden's residence; aluminum tablet stamped "627 ADJ 1904" (primary-traverse station) ...........

BRINK, NORTH TO CEDAR GROVE.

Cedar Grove, in foundation at northwest corner of Upper Seneca Baptist Church, 1 foot above ground; tablet stamped " 637 ".

637.309

KENSINGTON, NORTH ALONG HIGHWAY VIA AN INDIRECT ROUTE.TO OLNEX; THENCE NORTHWEST TO LAYTONSVILLE.

Kensington, between tracks at milepost "W. 11;" top of vertical rail section (Baltimore and Ohio Railroad bench mark 12)................

Kensington, I mile northwest of, between tracks at milepost "W. 12;" top of vertical rail section (Baltimore and Ohio bench mark 13) ..........

Garrett Park, 60 feet south of road crossing; top of west rail..............

Wheaton, on south side of store kept by J. C. Cissel; aluminum tablet stamped " 459 ".

Layhill, in south face at southeast corner of foundation of store kept by W. P. Beal; aluminum tablet stamped " 438 ".....................

Norbeck, south of road, west of forks, in north foundation wall of Arthur Stonestreet's store; aluminum tablet stamped " 499 ".

Olney, near southwest corner of town hall, in west face; aluminum tablet stamped " 544 ".

425. 189

627. 239

Olney, 2.6 miles northwest of, at road forks, in east face at northeast corner of house owned and occupied by Thomas Griffit; aluminum tablet stamped " 523 ".

285.566

300.0

459. 133

437.710

499. 038

543.573

522.795

ROCKVLLE, SOUTHWEST ALONG HIGHWAY TO GREAT FALLS.

Rockville, opposite milepost 17; top of vertical rail section (Baltimore and Ohio Railroad bench mark 18).

Rockville, top of corner stone in north side of court-house, 12 feet east of entrance, in granite foundation, 1 foot below water table; aluminum tablet stamped " 451 ".

451. 046

Rockville, 3.9 miles southwest of, road forks east, chimney at north side of schoolhouse; aluminum tablet stamped " 420 ".

Potomac, 100 feet southwest of crossroads, in north side of chimney, east side of house of Mr. Perry; aluminum tablet stamped "364 ADJ 1903"...

Great Falls, on the capstone near west end of south wall of Lock No. 20, Chesapeake and Ohio Canal, 0.200 meter from extreme north and 0.450 meter from extreme east edge of lock, 1.65 meters from west gate; bottom

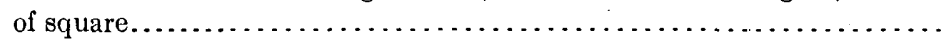

AT WASHINGTON GROVE AND GAITHERSBURG.

Washington Grove, between tracks opposite milepost 21; rail (Baltimore and Ohio bench mark).

Gaithersburg, R. A. Young's store, northwest corner Fredericksburg avenue and Chestnut street; primary-traverse tablet stamped " 508 ".........

\section{SENECA QUADRANGLE.}

AT GERMANTOWN.

Germantown, 50 feet south of bridge over railroad, west of road, east face at northeast corner of house occupied by C. E. Keeper and owned by H. D. Waters; aluminum tablet stamped " 449 " 
Germantown, 0.6 mile northwest of, at milepost "W. 27 "; top of vertical rail section.

GATTHERSBURG, SOUTHWEST TO DARNESTOWN; THENCE WEST TO POOLESVILLE; THENCE NORTH TO BARNESVILLE.

Darnestown, Windsor store, brick foundation to cellar door; tablet stamped " 436 "

Dawsonville, in north wall of Allnut ice house; tablet stamped "305"...

Poolesville, in south wall of T. R. Hall's brick house; tablet stamped " 41.5 ".

Barnesville, 0.25 mile east of, at milepost 33 on Baltimore and Ohio Railroad; vertical rail.

POOLESVILLE, SOUTHWEST TO EDWARDS FERRY.

Edwards Ferry, Chesapeake and Ohio Canal Lock No. 25, southwest corner; primary-traverse tablet station 88 stamped " 207 "

BRINK, NORTHWEST TO CLARKSBURG.

Clarksburg, near southwest corner of west foundation wall of M. E. Church South; aluminum tablet stamped " 658 ".

WASHINGTON, D. C., TO WASHINGTON JUNCTION.

Milepost "W. 37," at southeast corner of culvert; copper bolt (bench mark

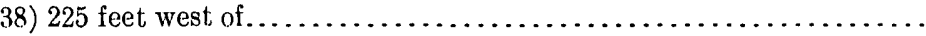

Tuscarora, 150 feet west of milepost 39 , south end of east wall of box culvert; copper bolt (bench mark 40A).

\section{Middletown and Martinsburg quadrangles. FREDERICK AND WASHINGTON COUNTLES.}

The following elevations are based on precise-level lines of the Coast and Geodetic Survey and the Baltimore and Ohio Railroad which traverse this area. Elevations in Virginia for Middletown quadrangle are given on page 62 , and those in West Virginia have been published in Bulletin 399.'

The leveling was done mostly in 1907 by W. R. Winstead; but some work was done in each quadrangle in 1908 by J. M. Harris.

\section{MIDDLETOWN QUADRANGLE.}

HARPERS FERRY, EAST ALONG BALTIMORE AND OHIO RAILROAD, TO BRUNSWICK; THENCE NORTH ALONG HIGHWY, TO PETERSVLLE; THENCE EAST TO JEFFERSON; THENCE SOUTH TO POINT OF ROCKS.

Harpers Ferry, 0.6 mile east of, about 2.5 miles west of Weverton, about 400 feet east of Harpers Ferry tunnel, 300 feet west of milepost "B. 81 ," in box culvert on south side of railroad, in southeast abutment; iron plug (Baltimore and Ohio bench mark 56).

Sandy Hook, south track in front of station; top of south rail marked "270.U.S."

270. 2

Sandy Hook, 0.5 mile east of, 170 feet west of milepost "B.80," in center of double track; iron rod with " $\mathrm{X}$ " on top driven in ground, marked "264 U.S.B.M."

Weverton, 125 feet west of station, 50 feet west of road crossing, 15 feet north of track, in southwest pillar of Baltimore and Ohio Railroad water tower; aluminum tablet stamped "MARYLAND-260-ADJ" 
Weverton, 2.8 miles east of, 1,000 feet west of Brunswick station, on northeast corner of north abutment of culvert; point marked " 250 U.S.B.M.".

Brunswick, north track at street crossing; top of north rail marked " 249.5 U.S.".

Feet.

249.78

Brunswick, opposite post-office, in southeast corner of Savings Bank; aluminum tablet stamped "MARYLAND-266-ADJ"

249.4

266. 416

Petersville, 0.2 mile east of, at public road fork, in front face of east side of Lutheran Church; aluminum tablet stamped "MD-524-ADJ".........

Petersville, 2.4 miles east of, at foot of hill, south side of east end of covered bridge over Catoctin Creek, on top of large iron bolt; point marked "291. U.S.B.M."

Jefferson, 300 feet west of electric car station, at Frederick-Picke-Catoctin road fork, northwest corner of schoolhouse; aluminum tahlet stamped "MARYIAND-583-ADJ"

523.505

290.72

582.967

Jefferson, 1.6 miles south of, at foot of hill at road fork to Catoctin station; large iron bolt in southwest abutment of iron bridge over stream, marked " 417 "

Jefferson, 2.5 miles south of, at font of hill, 600 feet west of brick house, on top of northeast abutment of bridge over creek; point marked " 454 "...

Jefferson, 3.9 miles south of, at foot of hill, about 1,000 feet north of W. C. Adams's residence, in west abutment of culvert over small stream; aluminum tablet stamped "MARYLAND-389-ADJ"

388.538

WEVERTON, ALONG HIGHWY NORTH, TO POINT 2.7 MILES NORTH OF ROHERSVILLE; THENCE EAST TO MIDDLETOWN; THENCE SOUTH TO JEFFERSON.

Weverton, 1.7 miles north of, 400 feet north of stream, road fork west at top of hill, road fork east, on top of stone at blacksmith shop; point marked "545".

Brownsville, at road fork east, northwest corner of post-office; aluminum tablet stamped " 533 ".

544.72

532. 372

Gapland, 100 feet north of station, on rock near telephone pole; point marked " 619.5 ".

Rohersville, 10 feet south of main entrance of post-office, southeast corner of front face; aluminum tablet stamped " 624 ".

Rohersville, 1.8 miles north of, on northeast corner of southwest abutment of bridge over stream; point marked " 480 ".

Rohersville, 2.8 miles north of, 400 feet west of T road, 30 feet north of road, in stone; aluminum tablet stamped "MARYLAND-508-ADJ"........

Rohersville, 5 miles northeast of, at top of mountain, in front of house at second-class crossroads, 4 feet north of road, on top of stone; point marked " 1059 ".

Bolivar, at crossroads, at southwest corner of stone-arch bridge over stream,

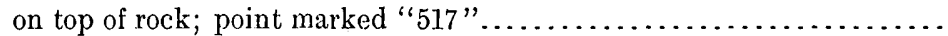

Bolivar, 1.1 miles northeast of, at foot of hill, at southwest end of culvert over small stream, in front of brick house, on top of land line stone; point

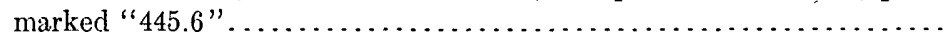

Middletown, in front face of post-office building; aluminum tablet stamped "MARYLAND-547-ADJ"

Middletown, 2.7 miles south of, at foot of hill near small stream, 200 feet west of house, 250 feet north of creamery, 15 feet west of road, in top of large rock; aluminum tablet stamped "MARYLAND-482-ADJ"......

Middletown, 4.6 miles south of, at foot of hill, at second-class crossroads, on northeast abutment of bridge over stream; point marked " 432 "..... 
HARPERS FERRY, NORTI TO ANTIETAM CREEK.

Farpers Ferry, 0.9 mile north of, 300 feet east of lock on canal, at secondclass road fork northeast, 10 feet west of road, on top of large rock; point marked " 276 ".

Harpers Ferry, 3.3 miles north of, at foot of hill, on northwest abutment of bridge over stream; point marked " 422 ".

Harpers Ferry, 4.2 miles north of, at crossroads near schoolhouse and church, in front face of schoolhouse 4 feet east of main entrance; aluminum tablet stamped "MARYLAND-623-ADJ".

Harpers Ferry, 6.6 miles north of, on northwest corner of Chesapeake and Ohio Canal lock; point marked " 300 ".

Harpers Ferry, 7.9 miles north of at Antietam west abutment of Chesapeake and Ohio Canal aqueduct; aluminum tablet stamped "MD-301-ADJ"

Feet.

275.86

421. 48

300. 13

300.470

SHARPSHURG, NORTHEAST TO KEEDYSVILLE; THENCE SOUTHEAST TO POINT 2.7 MILES NORTH OF ROHERSVILLE.

Sharpsburg, in front face of post-office building, 20 feet north of main entrance; aluminum tablet stamped "MARYLAND-413-ADJ".......

Sharpsburg, 1.4 miles northeast of, at foot of hill, 300 feet southwest of tollgate; nail in center of north side of iron bridge over Antietam Creek, marked " 337 ".

Keedysville, 50 feet north of railroad, in front face of hotel; aluminum tablet stamped "MARYLAND-404-ADJ".

Keedysville, 1 mile southeast of, at road fork north, at arch bridge over small stream; center of stone marked " 402.5 "

MYERSVILLE, SOUTH TO MIDDLETOWN.

Myersville, 2.3 miles south of, north-south road, T road east, on top of large rock in northeast corner between county road and railroad; chiseled square marked "G.S. $\square 644$ B.M.".

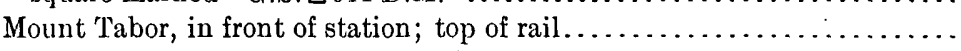

Mount Tabor, 330 feet southwest of, in northeast corner of Peter Leatherman's brick house; aluminum tablet stamped " $588 \mathrm{MD}$ "...........

644.06

584.5

587.758

MARTINSBURG QUADRANGLE.

ANTIETAM. WEST aLONG hIGHWAY, to SHEPHERDSTOWN, W. VA.; THENCE NORTHEAST to SHARPSHURG; THENCE NORTH TO GRIMES.

Shepherdstown, 1.3 miles northeast of, 150 feet west of second-class road crossing, 100 feet west of barn, on northwest abutment of culvert of Norfolk and Western Railway; point marked " 430 ".

Grimes, 1.2 miles south of, 500 feet south of county road crossing, west of railroad at cut, on large rock; chiseled square marked "G.S. $\square$ B.M. $415 "$

Grimes, 2.2 miles south of, on east side of railroad in north mouth of cut, on

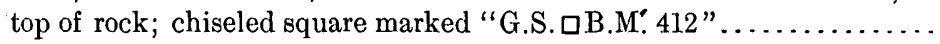

Mondel, in front of station; top of rail...........................

Mondel, 2 miles south of, on east side at north end of cut, on top of rock; chiseled square marked "G.S. $\square$ B.M. 458 ".........................

Sharpsburg, in front face of post-office building, 20 feet north of main entrance; aluminum tablet stamped "ADJ 413 ":
429.58

418.8

457.39

413. 077 
Emmitsburg, Hagerstown, Taneytown, and Williamsport quadrangles.

CARROLL, FREDERICK, AND WASHINGTON COUNTIES.

The following elevations were determined by primary leveling extended from Baltimore and Hagerstown and from the Baltimore and Ohio precise-level line from Relay to Washington Junction. The leveling was done in 1908, as follows: In Taneytown quadrangle. and most of Emmitsburg quadrangle, by C. H. Semper; in Hagerstown and Williamsport quadrangles and part of Emmitsburg quadrangle, by J. M. Harris. The standard bench marks are stamped with the state name.

TANEYTOWN QUADRANGLE.

WESTMINSTER, WEST ALONG WESTERN MARYLAND RAILROAD, TO DETOUR.

Westminster, in fifth step of main entrance to court-house; bronze tablet stamped " 774 "

Feet. 774. 537

Spring Mills, in front of station sign; top of rail.

607.2

Spring Mills, 250 feet west of station, at east end of north side of railroad culvert on top of mud wall; chiseled square marked "U.S. $\square$ B.M. 602"...

Avondale, in front of station; top of rail.........................

Avondale, 210 feet west of station, on north side of track, on top of railroad culvert; chiseled square marked "U.S. QB.M. 559 "................

Medford, in northwest corner of foundation of C. E. Engle's building at station; aluminum tablet stamped " 531 "......................

Medford, in front of station; top of rail...........................

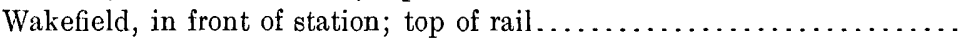

New Windsor, 1.4 miles east of, south of track, on top of railroad culvert;

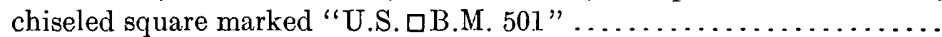

New Windsor, 0.3 mile east of, north side of east abutment of railroad bridge, in top of second step of retaining wall; aluminum tablet stamped " 452 ".

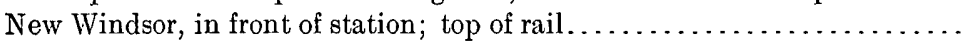

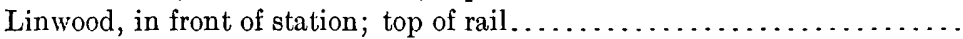

Union Bridge, 0.8 mile east of, north side of east abutment of railroad bridge, on top of retaining wall; chiseled square marked "U.S. $\mathrm{B} . \mathrm{M}$. $405 "$

602.31

560.5

558.77

531.401

530.0

515.9

500.95

451.991

445. 7

415.8

Union Bridge, at railroad station, in southeast corner of front face of First National Bank; aluminum tablet stamped " 402 ".

404. 56

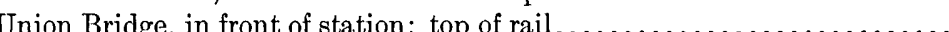

Middleburg, 1.5 miles east of, in top of bridge seat of east abutment on north side of railroad culvert; aluminum tablet stamped " 398 "........

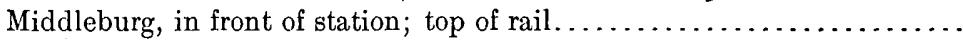

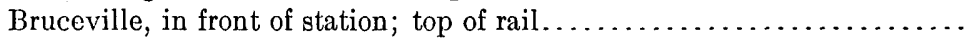

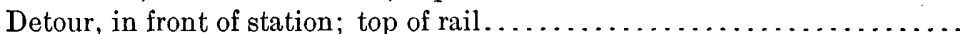

402.204

399.2

398. 380

461.6

453. 1

349.1

LADIESBURG, NORTHEAST ALONG NORTHERN CENTRAL RAILWAY, TO KINGSDALE.

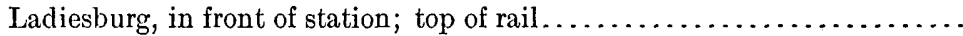

Ladiesburg, 1.6 miles north of, south abutment of steel railway bridge, east of track, in top of retaining wall; aluminum tablet stamped " 403 ".....

Bruceville, 50 feet north of overhead crossing of Western Maryland Railroad, 6 feet east of track, on concrete foundation to brick gasoline house, chiseled square marked "U.S.ロB.M. 433".....................

Bruceville, in front of station; top of rail ....................... 
Sharretts, in front of station sign; top of rail

Feet.

Crabster, in front of station sign at crossing; top of rail.................

Taneytown, Baltimore street crossing railroad, east of track, south of road, foundation of railroad-crossing sign; chiseled square marked "U.S. $\square$ B.M. "501.".

Taneytown, in southwest corner of Central Hotel; aluminum tablet stamped " 524 ".

513.4

500.71

523.476

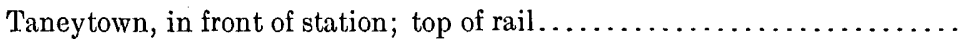

Taneytown, 1.9 miles north of, at railway crossing, 10 feet east of track, north of road, foundation of crossing sign; aluminum tablet stamped " 494 "

Galt, at station, west of track, south of road, foundation of crossing sign;

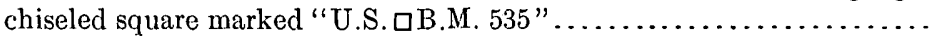

Piney Creek, in front of station; top of rail......................

KINGSDALE, SOUTHEAST TO UNION MHLLS.

Kingsdale, 3.6 miles southeast of, on Baltimore pike, in northwest corner of front face of F. T. Brown's brick house; aluminum tablet stamped " 705 ".

Union Mills, in foundation on northwest side of Shriver's grain mill, 2 feet from corner; bronze tablet stamped " 546 " .....................

704.572

544.545

EMMITSBURG QUADRANGLE.

ẆALKERSVILLE, NORTHEAST ALONG NORTHERN CENTRAL RAILWAY, TO LADIESBURG.

McAleer, in front of station; top of rail..........................

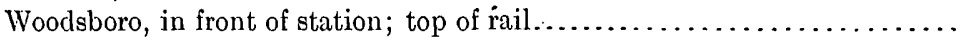

Woodsboro, at railway station, in northeast corner of foundation of flour mill; aluminum tablet stamped " 411 "........................

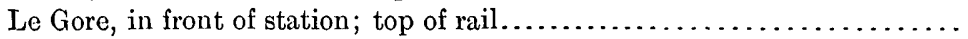

New Midway, at station, at road crossing, 8 feet east of track, 6 feet north of highway, foundation of railway crossing sign; aluminum tablet stamped " 462 ".

411. 302

434. 2

New Midway, in front of station; top of rail......................

DETOUR, WEST AND NORTHWEST ALONG WESTERN MARYLAND RAILROAD, TO THURMONT AND BUENA VisTA SPRING.

Detour, 1,300 feet west of station, at road crossing, north of track, on outcrop; chiseled square marked "U.S. $\square$ B.M. 341 "

Detour, 0.35 mile north of, at railroad crossing, in east face about 6 feet from southeast corner of stone foundation to E. D. Diller's house; aluminum tablet stamped "Prim. Trav. Sta. No. 1, 447"...............

Detour, 1.5 miles west of, on south wall of west abutment of railroad bridge over river; chiseled square marked "U.S. $\square$ B.M. 335 " .

Detour, 2.7 miles west of, 20 feet north of track, east of overhead bridge, on large rock; chiseled square marked "U.S. QB.M. 407" ...............

Rocky Ridge, in front of station; top of rail......................

Rocky Ridge, opposite railroad station, in northwest corner of foundation of Robert Biggs's brick house; aluminum tablet stamped " 397 "........

Loys, railroad crossing at station; top of rail......................

Graceham, 450 feet east of station, in top of south end of east abutment to overhead railroad bridge; aluminum tablet stamped " 441 "............

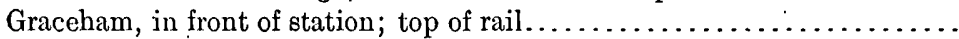

Thurmont, 2.1 miles northwest of, on top of south end of west abutment of high bridge 97; chiseled square marked "U.S. $\square$ B.M. 715 " ............

406. 59

400.4

397. 1.38

356.4

440. 659

448.7

714. 52 
Thurmont, 2.9 miles northwest of, in top of mud wall at south side of west abutment of steel bridge over Owens Creek; aluminum tablet stamped

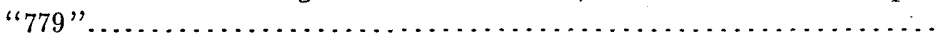

Thurmont, 4 miles northwest of, at west end of switch, south of track, on large rock; chiseled square marked "U.S. $\square$ B.M. 889 " ...............

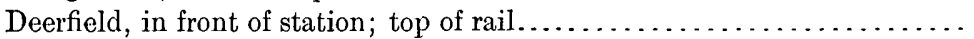

Deerfield, 1.2 miles northwest of, on top of mud wall at south end of west wall of railroad culvert; chiseled square marked "U.S. QB.M. 106t" ... 1, 063.58

Sabillasville, in southeast corner of front face of St. Marks Lutheran Church;

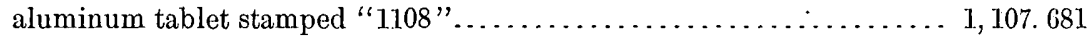

Sabillasville, in front of station; top of rail........................ 1, 140. 0

Highfield, in front of station; top of rail....................... $1,390.2$

Buena Vista Spring, in front of station; top of rail.................. 339.9

THURMONT, SOUTH TO CHARLESVILLE.

Thurmont, in front of station; top of rail.

Thurmont, in east face at northeast corner of Thurmont National Bank Building; aluminum tablet stamped "Prim. Trav. Sta. No. 6, 523"....

Thurmont, 2 miles south of, at railroad crossing, 40 feet west of track, on north margin of road, on top of bowlder; chiseled square marked

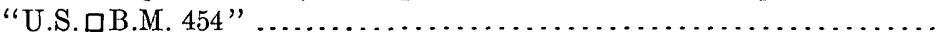

Catoctin, in front face of stone furnace building, north side of door; aluminum tablet stamped " 497 ".

Lewistown, in front face at north corner of stone house just south of church; aluminum tablet stamped " 402 "

Lewistown, in front of station; top of rail.

454. 17

496. 753

402. 234

Lewistown, 1.1 miles south of, on top of mud wall at east end of south wall of concrete railroad culvert; chiseled square marked "U.S. $\mathrm{B}$ B.M. 403".

ROCKY RIDGE, NORTH TO EMMITSBURG; THENCE WEST TO SABILLASVILLE.

Motters, in front of station; top of rail.

445. 2

Motters, in front of station, in southeast corner of foundation of hay scales; aluminum tablet stamped " 445 ".

403. 07

Motters, 0.7 mile north of, on top of east side of south wall of cattle pass under railroad; chiseled square marked "U.S. $\square$ B.M. 438"

Emmitsburg, in front of station; top of rail.

Emmitsburg, in front face of Dutch Reformed Church; aluminum tablet stamped " 450 ".

Emmitsburg, 1.4 miles west of, 50 feet east of crossroad on north side, schoolhouse at crossroads, on top of large bowlder; chiseled square marked "U.S. $\square$ B.M. 442 ".

Emmitsburg, 2.3 miles west of, 280 feet west of brick house, south side of road, on large bowlder; chiseled square marked "U.S. $\square$ B.M. 643 ".....

Emmitsburg, 4.5 miles west of, 10 feet north of road, on top of large rock; chiseled square marked "U.S. $\mathrm{B}$ B.M. 1176 "................... 1, 175. 29

Emmitsburg, 5.3 miles west of, in northeast corner of stone foundation of William Miller's house; aluminum tablet stamped " $1150 \mathrm{MD}$ "....... 1, 149. 583

Emmitsburg, 5.5 miles west of, in forks of road, on top of small bowlder; chiseled square marked "U.S. $\square$ B.M. $1082 " \ldots \ldots \ldots \ldots \ldots \ldots \ldots \ldots \ldots \ldots \ldots \ldots, 081.97$

Emmitsburg, 6 miles west of, north of road, on top of large bowlder; chiseled square marked "U.S. (B.M. 1008"........................ 1, 007.64

Emmitsburg, 7.1 miles west of, north of road, 900 feet west of stream, halfway up hill, on top of large bowlder; chiseled circle marked "U.S.๑B.M.

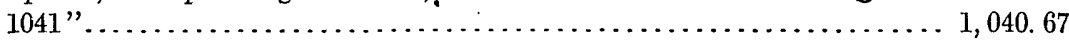




\section{HAGERSTOWN QUADRANGLE.}

BUENA VISTA SPRING, WEST ALONG WESTERN MARYLAND RAILROAD, TO HAGERSTOWN.

Lake Royer, 0.3 mile west of Buena Vista Spring; surface of water May 22, Feet.

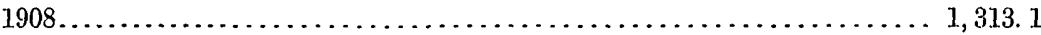

Pen Mar, 175 feet east of, 10 feet south of track opposite store, on top of large bowlder; chiseled square marked "U.S. $\mathrm{B}$ B.M. 1248"............... 1, 247. 44

Pen Mar, in front of station; top of rail.......................... 1, 244. 4

Blue Mountain, in front of station; top of rail................... 1, 178. 0

Blue Mountain, in northwest corner of brick railroad station; aluminum tablet stamped " $1189 \mathrm{MD}$ "............................. 1, 188. 873

Blue Mountain, 1 mile west of, 40 feet south of track, on top of large bowlder; chiseled square marked "U:S. $\square$ B.M. 1106 "................. 1, 106. 33

Blue Mountain, 2.1 miles west of, 6 feet south of track, on top of large bowlder; chiseled square marked "U.S. 口B.M. 1025".................. 1., 025. 12

Edgemont, in front of station; top of rail...................... 965.5

Edgemont, 225 feet west of station, 40 feet south of track, in north foundation wall of Bachtell's store and post-office; aluminum tablet stamped " $961 \mathrm{MD} "$. ............................................

Smithsburg, in front of station; top of rail

Smithsburg, 150 feet west of station, in southeast corner of Western Maryland Railroad brick warehouse; aluminum tablet stamped "800 MD" ..

Cavetown, in front of station; top of rail.........................

Cavetown, 1 mile west of, 15 feet east of whistle post, 8 feet south of track, on top of large bowlder; chiseled square marked "U.S. QB.M. 697 ".....

Cavetown, 1.7 miles west of, 8 feet south of track, 400 feet west of milepost 80 , on rock in bank; chiseled square marked "U.S. $\square$ B.M. 651 "........

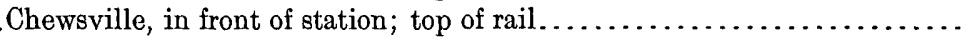

Chewsville, in north face at northwest corner of brick railroad station building; aluminum tablet stamped " $636 \mathrm{MD}$ "

799. 81.9

751. 3

Chewsville 11 miles west of, 300 feet east of overhead road bridge, 4 feet north of track, on top of large bowlder; chiseled square marked "G.S. 口B.M. $580 "$

Security, in front of station; top of rail........................

Security, 0.3 mile west of, south of track, in top of east back wall of bridge over Marsh Run; aluminum tablet stamped " 508 MD" ..............

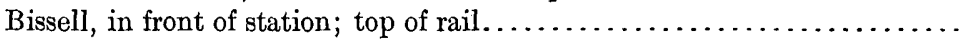

Potomac avenue, in front of station; top of rail ....................

North Junction, main line Western Maryland Railroad and northbound track of Altenwald cut-off, at frog point; top of rail.................

North Junction, intersection of the Cumberland Valley and the Western

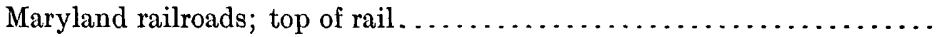

Hagerstown, corner Washington and Jonathan streets, on Jonathan street side of court-house; water table (Coast and Geodetic Survey bench mark 18; old elevation obtained from office) $\ldots \ldots \ldots \ldots \ldots \ldots \ldots \ldots \ldots \ldots$.

507.807

564.5

589.6

590.5

EDGEMONT, NORTH ALONG WESTERN MARYLAND RAILROAD, TO MIDVALE.

Shockeys, in front of sign; top of rail..........................

SMITHSBURG, SOUTH TO MYERSVILLE; THENCE NORTHWEST TO HAGERSTOWN.

Smithsburg, 2.5 miles south of, on top of Blue Mountain, in northwest corner of roads opposite a 2-story frame house, on top of large rock; chiseled square marked "G.S. $\square$ B.M. 1512" ........................... 1, 511.. 32 
Smithsburg, 3.5 miles south of, 150 feet west of road, in southeast corner of east face of stone foundation of frame schoolhouse; aluminum tablet stamped " 1335 MD".

Feet.

Smithsburg, 4.6 miles south of, east of road, 50 feet north of 2-story stone house, on top of bowlder; chiseled square marked "G.S. $\square$ B.M.1117"... 1, 116. 70

Smithsburg, 5.6 miles south of, west of road, 20 feet south of wooden bridge over stream, on top of flat rock; chiseled square marked "G.S. BB.M. $1035 "$.

Wolfsville, at crossroads in center of, in northwest corner of roads opposite J. M. Woolf's house, in face of large curb stone; aluminum tablet stamped "1044 MD".

Wolfsville, 1.2 miles southeast of, west of road, 150 feet south of road forks, on top of large bowlder; chiseled square marked "G.S. $\square$ B.M. 931"....

Middlepoint, 0.6 mile south of, west of road, in $V$ of private road, on top of large flat rock; chiseled square marked "G.S. $\square$ B.M. 814"..........

Middlepoint, 1.6 miles south of, under corner stone in southwest corner of south face of Grossnickles (Dunkard) Church; aluminum tablet stamped "740 MD"

Middlepoint, 2.9 miles south of, under northeast corner of iron bridge over Catoctin Creek; chiseled square marked "G.S. $\square$ B.M. 663 ".

Ellerton, 1.4 miles south of, west of road, in east side of stone foundation of Tilman Grossnickle's spring house; aluminum tablet stamped " $582 \mathrm{MD}$ ".

Myersville, 1.9 miles north of, on west end of north abutment of small wooden trestle over hollow; chiseled square marked "G.S. 口B.M. 970"... 969.86

Wolfsville Crossing, at railroad crossing; top of rail................. 1,026.6

Wolfsville Crossing, 0.2 mile north of, 80 feet west of railroad, on line with second-story windows in east.side of John M. Fey's brick house; aluminum tablet stamped " $1085 \mathrm{MD}$ ".

$1,084.555$

Wolfsville Crossing, 2.5 miles north of, 5 feet east of trolley track, 390 feet south of railroad crossing, on top of large rock; chiseled square marked "G.S. $\square$ 835B.M."

Wolfsville Crossing, 3.1 miles north of, in north end of east face of Hagerstown and Myersville Railroad Company's brick power house; aluminum tablet stamped " $640 \mathrm{MD}$ ".

Smoketown, at railroad crossing; top of rail.

Wagners Crossroads, in front of station; top of rail.

West Beaver, railroad crossing at south ond of

West Beaver west end of rivet on top; chiseled square marked "G.S. $\square$ B.M. 480 ".....

West Beaver Creek, 1.2 miles north of, at crossroads, in north end of west face of brick schoolhouse on east side of road; aluminum tablet stamped "546 MD"

834.91

Funkstown, at north end of, in north end of east brick wall of Red Man hall;

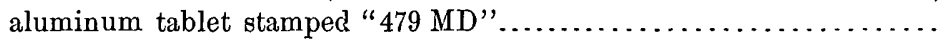

Hagerstown, 3.1 miles south of, 10 feet east of railroad, in northwest corner of large rock in bank; chiseled square marked "G.S. $\square$ B.M. 548"......

Hagerstown, 3.7 miles south of, 450 feet east of railroad, in west end of south face of Marsh Church, 2 feet above ground; aluminum tablet stamped "534 MD".

547.84

Hagerstown, 5.3 miles south of, 10 feet west of railroad and opposite school buildings, on large rock in bank; chiseled square marked "G.S. $\mathrm{BB} . \mathrm{M}$. 487 " 
HAGERSTOWN, SOUTHWEST 2 MLLES ALONG CUMBERLAND VALLEY RAILROAD (UNCHECKED SPUR LINE).

Hagerstown, Cumberland Valley Railroad, in front of station; top of rail. .

Feet.

573.5

575.6

590.990

\section{WILLIAMSPORT QUADRANGLE.}

ST. JAMES SCHOOL, SOUTII 'TO GRIMES.

St. James, in front of station; top of rail.

St. James, opposite station, 50 feet from track, under porch of two-story frame cottage; aluminum tablet stamped " $473 \mathrm{MD}$ "...............

St. James, 0.9 mile south of, on northeast corner of south bridge seat of railroad bridge 717 ; chiseled square marked "G.S. $\square$ B.M. 431".........

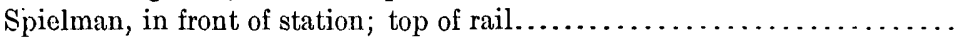
Spielman, 0.2 mile south of, railroad bridge 712, on northeast corner of south bridge seat; chiseled square marked "G.S. $\square$ B.M. 404 ".............

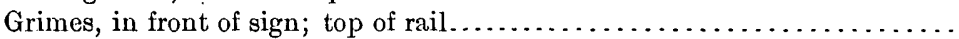

Grimes, 0.4 mile south of, railroad bridge 705 , in west end of north bridge seat; aluminum tablet stamped " $391 \mathrm{MD}$ ".

431. 05

408.4

403. 69

387.0

390.868

HAGERSTOWN, SOUTHWEST ALONG CUMBERLAND VALLEY RAILROAD, TO POTOMAC RIVER BRIDGE.

Hagerstown, 3.3 miles west of, 15 feet north of track, on top of large rock north of railroad; chiseled square marked "G.S. $\square$ B.M. 548".........

Halfway, 150 feet west of railroad, in southwest corner of front face of R. P. Beckley's concrete store on Williamsport pike; aluminum tablet stamped, "539 MD"

Halfway, in front of station; top of rail.

Halfway, 0.6 mile southwest of, 15 feet from track, on top of rock on north side of cut between milepost 78 and semaphore; chiseled square marked "G.S. $\square$ B.M. 525".

Halfway, 1.7 miles southwest of, 325 feet west of milepost 79 , on top of large rock in north bank of cut; chiseled square marked "G.S. $\square$ B.M. 487"..

Halfway, 2.9 miles southwest of, in center of south head wall of concrete box culvert under railroad between county road and railroad; aluminum tablet stamped " $447 \mathrm{MD}$ ".

Williamsport station, in front of; top of rail

Williamsport, 0.4 mile southwest of, north of railroad, about 300 feet west of milepost 81, on top of large rock in bank of cut; chiseled square marked "G.S. $\square$ B.M. $436 "$.

Williamsport, 1.3 miles southwest of, on south end of east abutment of back wall of Cumberland Valley Railroad bridge 82 1; chiseled square marked "G.S. (B.M. 382"......................................

Accident, Flintstone, Frostburg, Grantsville, Hancock, Oakland, Pawpaw, and Piedmont quadrangles.

ALLEGANY, GARRETT, AND WASHINGTON COUNTIES.

The elevations in the following list were determined by primary leveling extended from various bench marks of the Coast and Geodetic Survey transcontinental line. 
The leveling in Frostburg and Flintstone quadrangles was done mostly in 1897 by Hargraves Wood; that in Grantsville, Oakland, Accident, and part of that in Pawpaw and Hancock quadrangles was done in 1898 by C. B. Bailey and Hargraves Wood; and the remainder of the work in Pawpaw and Hancock quadrangles was done in 1899 by C. M. Smith.

\section{HANCOCK QUADRANGLE.}

HANCOCK, WEST ALONG BALTIMORE PIKE, TO GREEN RIDGE.

Hancock, on coping stone at middle of north wall of Chesapeake and Ohio Canal aqueduct, about 600 feet east of bridge; Coast and Geodetic Survey bench mark stamped " $1878 \mathrm{~F}$ ".

Feet.

Hancock, 5.15 miles west of, 0.25 mile east of Harveys, 100 feet west of road to Woodmont, south of pike, in solid rock; bronze tablet stamped " 946 C".

945. 743

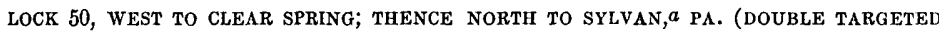
SPUR LINE).

Lock 50, Chesapeake and Ohio Canal, close to watch house, on west end of

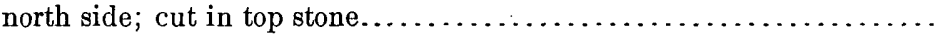

Lock 50,. Chesapeake and Ohio Canal, northeast wing; aluminum tablet stamped " $402 \mathrm{C}$ "

404.522

Cherry Run, W. Va., 1.5 miles north and 0.75 mile west of, in south side of southwest corner of wing wall of Chesapeake and Ohio Canal viaduct over Licking Creek, 4 feet from west end of wall, about 2 feet below coping, in second tier of masonry under coping; aluminum tablet stamped "MARY-

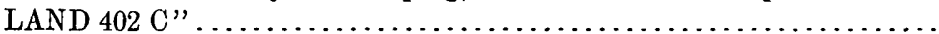

PAWPAW QUADRANGLE.

PRATT, ALONG HIGHWAYS, TO LITTLE ORLEANS.

Green Ridge, south of pike, west of road to Little Orleans, in small ledge of rock at top of ridge; 'bronze tablet stamped " $1204 \mathrm{C}$ " ............ 1, 204.237

Little Orleans, north end of east coping of Chesapeake and Ohio Canal aqueduct over Fifteenmile Creek; bronze tablet stamped " $459 \mathrm{C}$ "... . . . . . .

Little Orleans, square cut in coping stone of aqueduct over Fifteenmile Creek (Coast and Geodetic Survey bench mark XIII).

FLINTSTONE QUADRANGLE.

CUMBERLAND, ALONG OLD NATIONAL PIKE, TO PRATT.

Six-mile House; copper bolt in northeast corner of foundation, stamped "881 C"

Flintstone, Doctor Robinson's house, north west corner of foundation; bronze

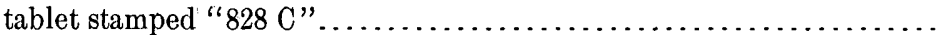

Flintstone, 2.75 miles east of, opposite telegraph pole, top of Polish Mountain; stone stamped " 1381 ".

Pratt, 0.25 mile east of former post-office, 150 feet west of Robinett's old house, south of road, in ledge of rock; aluminum tablet stamped " $938 \mathrm{C}$ ".

FLINTSTONE, SOUTH ALONG OLDTOWN ROAD, TO OLDTOWN.

Flintstone, sixth crossing of Town Creek from, 2 feet above grade of creek; copper bolt in ledge west of road to Oldtown, about 0.06 mile northeast of L. T. Shryock's, stamped " $666 \mathrm{C}$ "

\footnotetext{
a For elevation on this linę north of Maryland boundary see Bull, U, S, Geol, Survey No. 288, 1906: p. 30
} 
LOCK 67, WEST ALONG CHESAPEAKE AND OHIO CANAL, TO CUMBERLAND.

Lock 67, Chesapeake and Ohio Canal; coping stone (Coast and Geodetic Survey bench mark "XV").

Old town, 15 feet east of west end of Lock 70; copper bolt in coping stone of south wall, stamped " $564 \mathrm{C}$ "

\section{FROSTBURG QUADRANGLE.}

CUMBERLAND, NORTH AND WEST ALONG CUMBERLAND AND PENNSYLVANIA RAILROAD VIA MOUNT SAVAGE, To FROSTBURG.

Cumberland, coping of feed lock of canal; Coast änd Geodetic Survey bench mark stamped "I.B.M.U.S.C.\& G.S. 1878".

Cumberland, northeast corner of court-house, in top of stonework; bronze tablet stamped " $688 \mathrm{C}$ ".

Mount Savage, 1,000 feet east of station, in southwest abutment of high bridge over Sulphur Creek; copper bolt stamped "1198 C"........... 1, 198. 508

Frostburg, 50 feet east of tunnel, on Cumberland and Pennsylvania Railroad, in south side of rock cut; bronze tablet stamped " $1929 \mathrm{C}$ "....... 1, 929.178

FrostBurg, SOUTH AND EAST ALONG CUMBERLAND AND PENNSYllania RAILROAD, TO CUMBERLAND.

Vale Summit, 250 feet west of station and 100 feet south of Georges Creek and Cumberland Railroad; copper bolt in large bowlder, stamped "1993 C"

Clarysville; platform at station............................. 1,638. 0

Park station (Casino); Georges Creek and Cumberland Railroad platform.. $\quad 757.3$

GRANTSVILLE QUADRANGLE.

FRostburg, Via PINEY GROVE, NEW GERMANY, AND CRABTREe, TO BLOOMINGTON.

Piney Grove, 0.5 mile east of, near east corner of large house north of pike, 200 feet west of Twomile Run; bronze tablet stamped " 2424 C". . 2, 424. 545

New Germany, 0.1 mile east of, 100 feet east of Poplar Lick Run, 20 feet south of road to Oakland at intersection of road to old mill, in ledge of rock; bronze tablet stamped " $2472 \mathrm{C}$ ".

New Germany, 8 miles south of, Savage River at mouth of Bear Pen Run, 0.15 mile west of, at edge of clearing, north side of road down Bear Pen Run, in ledge of rock; bronze tablet ${ }^{a}$ stamped " $1578 \mathrm{C}$ "........... 1, 578. 174

Floyd, 0.12 mile east of railroad station (known as Jrankville), 0.09 mile west of milepost "214 to Baltimore," south of Baltimore and Ohio Railroad, at east end of frame house, in large rock; bronze tablet stamped "1693"

Floyd, 2.6 miles east of, 100 feet east of signal at station, south of Baltimore and Ohio Railroad, bench mark in Laffey Rock; bronze tablet stamped

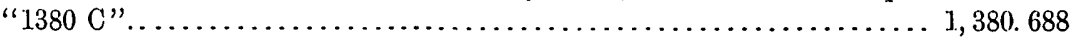

PINEY GROVE, WEST VIA GRANTSVILLE, TO KEYSER.

Grantsville, Farmers' Hotel, in southeast corner stone, opposite milepost "1. $\mathrm{mi}$. to Frostburg" and "106 mi. to Wheeling;" aluminum tablet

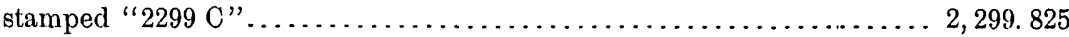

Keyser, northeast corner of stone foundation wall of former post-office building; bronze tablet stamped " $2879 \mathrm{C}$ " $\ldots \ldots \ldots \ldots \ldots \ldots \ldots \ldots \ldots \ldots \ldots \ldots \ldots \ldots \ldots \ldots, 880.585$ 
PIEDMONT QUADRANGLE.

AT BLOOMINGTON.

Bloomington, on top step at northwest corner of Baltimore and Ohio Railroad bridge over Potomac River; Coast and Geodetic Survey bench Feet.

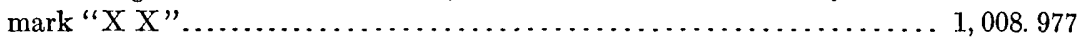

\section{ACCIDENT QUADRANGLE.}

NEW GERMANY, SOUTHWEST VIA MEADOW MOUNTAIN ROAD, TO THAYERVILLE.

Thayerville, 5.8 miles east of, north of Meadow Mountain road, near Meadow Mountain Run, in rock 500 feet northeast of old sawmill site; bronze tablet stamped " 2573 "

THAYERVILLE, NORTH VIA M'HENRY, HOYES, AND ACCIDENT, TO KEYSER.

Hoyes, southeast corner of foundation wall of Catholic Church; aluminum tablet stamped " $2611 \mathrm{C}$ " ............................... 2, 612. 308 Accident, in northeast corner of foundation of English Lutheran Church; aluminum tablet stamped " $2394 \mathrm{C}$ " ........................ 2, 395. 491

M'HENRY, VIA SANG RUN, FRIENDSVILLE, AND SHELBYSPORT, TO SOMERFIELD, PA.; THENCE SOUTHEAST TO KEYSER.

Friendsville, southeast corner of First avenue and Maple streets, in east foundation wall of building owned by L. E. Friend; aluminum tablet

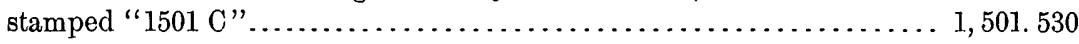

Sang Run, in abutment of bridge over Youghiogheny River; bronze tablet stamped "1989 C"........................................ 1, 988. 899

Oakton, Pennsylvania-Máryland boundary; base of monument. . . . . 2, 362. 86

\section{OAKLAND QUADRANGLE.}

OAKLAND, NORTHEAST TO THAYERVILLE.

Oakland, 1.25 miles west of, top of southwest abutment of Baltimore and Ohio Railroad bridge over Youghiogheny River; U. S. Coast and Geodetic Survey bench mark................................ 2, 376. 009

Oakland; copper bolt on top of south meridian stone in court-house, stamped "2461 C" .......................................... 2,460.859

Oakland, southwest corner stone of court-house; aluminum tablet stamped " $2473 \mathrm{C} "$

OAKLAND, SOUTH TO REDHOUSE; THENCE EAST TO GORMAN; THENCE NORTH VIA KEARNEY AND DEER PARK, TO MOUNTAIN LAKE.

Redhouse, southwest corner stone of school building; aluminium tablet

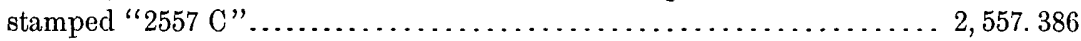

Redhouse, 2.6 miles east of, 4 corners on top of Backbone Mountain, on bowlder 10 feet south of spring; chiseled square................. $3,073.93$

Gorman, at west end of north abutment of highway bridge over Potomac River; aluminum tablet stamped " $2312 \mathrm{C}$ "................... 2,312.574

Kearney, 2.2 miles northeast of, 900 feet west of Taskers Corners, 600 feet east-southeast from barn in Jerry Tasker's upper field; aluminum tablet

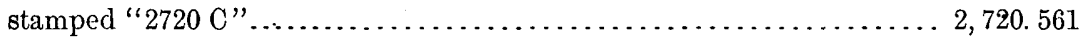

Deer Park, between two Baltimore and Ohio stations; 725 feet east of Deer Park Hotel station, surface of southwest wing wall of abutment of stone culvert; aluminum tablot stamped " $2447 \mathrm{C}$ ".................. 2, 447. 328 
Mountain Lake, 3 miles east of Oakland, on top of the southwest corner of west abutment of railroad bridge over Little Youghiogheny River; point Feet. marked "B口M" (Coast Survey bench mark XXII) .............. 24, 404. 813

AT THAYERVILLE.

Thayerville, 700 feet from, south of Meadow Mountain road, 150 feet east of its intersection with Thayerville-Oakland road, in bowlder; bronze tablet stamped " $2493 \mathrm{C}$ ". $2,493.953$

\section{VIRGINIA.}

\section{PRECISE LEVELING.}

Clarksville, Clifton Forge, Fincastle, Leslie, Lewisburg (30'), Martinsville, Natural Bridge Special, Rocky Mount (30'), and Roanoke (30') quadrangles.

ALLEGHANY, BOTETOURT, FRANKLIN, HENRY, MECKLENBURG, AND ROANOKE COUNTIES.

The following list embodies the Virginia portion of the results of two lines of precise levels. The first line, a spur, from Durham, N. C., to Clarksville, Va., was run in 1905 by R. L. Libbey. The second line, from Greensboro, N. C., to Lock No. 6, near Charleston, W. Va., was run in three sections: (1) from Greensboro, N. C., to Buchanan, Va., along the Norfolk and Western Railway, in 1905, by R. L. Libbey; (2) from Buchanan to Moss Run, along the Chesapeake and Ohio Railway, in 1906, by N.A. Campbell; and (3) from Moss Run to Lock No. 6, along the Chesapeake and Ohio and the Kanawha and Michigan railways, in 1907, by C. H. Semper.

The closure error of the second line upon the United States Engineer Corps elevation at Lock No. 6, corrected to accord with the 1903 adjustment, was 0.732 foot high; but this error has been removed by adjustment over a total distance of 365 miles.

These lines were leveled independently in both forward and backward directions, broken by temporary bench marks into sections 0.5 mile to 1.5 miles in length. On all sections on which the backward and forward measures differed by more than the allowable limit of error, the forward and backward measures were repeated until a pair run in opposite directions agreed within such limit; and all the other requirements necessary to obtain accurate results were closely adhered to.

The instruments used in 1905 were two self-reading rods; 3.2 meters in length (graduated to centimeters and reading by estimation to millimeters), one Coast and Geodetic Survey precise level, and one large shade umbrella. For the work of 1906 and 1907 rods graduated to yards and decimals were substituted for metric, to facilitate reduction of elevations to feet. These survey parties of each year consisted of 5 persons -2 rodmen, 1 umbrella man, and 1 recorder, under the direction of the levelman in charge.

$53492^{\circ}-$ Bull. $434-10-4$ 


\section{CLARKSY ILLE QUADRANGLE.}

SOUDAN, NORTH TO CLARKSVILLE.

Soudan, 125 feet west of south switch of siding, in southeast corner of W. L. Averett's yard; iron post stamped " 312 " (bench mark U)............

Clarksville, 2.5 miles south of, 60 feet west of Southern Railway tracks, at edge of woods directly opposite milepost 34 ; iron post stamped " 326 "

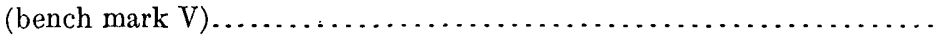

Clarksville, 25 feet south of lower station, 5 feet above track, in face of rock cut; aluminum tablet stamped " 286 " (bench mark W).

Feet.

311. 964

Clarksville, on south side of Main street, between sidewalk and gutter, 125 feet west of tracks; iron post stamped " 286 " (bench mark X) . . . . . . . .

Clarksville, in southeast corner of west abutment pier of Southern Railway bridge; aluminum tablet stamped " 288 " (bench mark Y)............

MARTINSVILLE QUADRANGLE.

PRICE, N. C., NORTH ALONG NORFOLK AND WESTERN RAILWAY, TO BASSETT.

Ridgeway, in front of station; top of rail.

Ridgeway, 175 feet northeast of station; 85 feet east of railway track, 30 feet east of county road, nearly opposite road-crossing sign; iron post stamped " 834 ".

285.886

287.568

Ridgeway, 3.5 miles north of, 200 feet northwest of milepost 54, 600 feet south of mail crane, 50 feet west of railway track; iron post stamped " 720 "

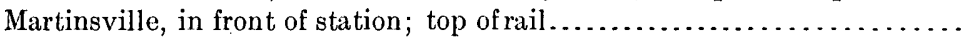

Martinsville, 350 feet northwest of station, 300 feet north of railway track, 10 feet east of College street, in southwest corner of S. F. Pedigo's yard; iron post stamped " 947 ".

Martinsville; 2.5 miles northwest of, 60 feet west of Martinsville-Bassett wagon road, 40 feet north of railway track, 600 feet northwest of milepost 62 ; iron post stamped " 773 "

954.2

947.268

Martinsville, 5.5 miles north of, 660 feet north of milepost 64 , in south abutment of concrete railway culvert 1,870 ; aluminum tablet stamped " 729 ".

Bassett, 3.5 miles south of, 200 feet south of milepost 66 , in west side of first stone culvert, south of milepost 66 ; square cut ................

ROCKY MOUNT $\left(30^{\prime}\right)$ QUADRANGLE.

BASSETT, ALONG NORFOLK AND WESTERN RAILWAY, TO ROCKY MOUNT.

Bassett, in front of station; top of rail.

758. 6

Bassett, near southeast corner of yard of Jasper Bassett, outside of front fence, 10 feet west of wagon road, 75 feet southwest of road crossing, nearly opposite Bassett furniture factory; iron post stamped " 762 ".....

Town Creek, 200 feet northeast of Philpotts's store, 200 feet sou theast of milepost 73 , southeast of railroad; iron post stamped " 798 " .............

Town Creek, 0.25 mile north of, 120 feet northwest of railway crossing, in top of southeast wing wall of railway bridge 1860; aluminum tablet stamped " 803 "

Henry, 0.5 mile south of, in top of northwest wing wall of concrete railway bridge 1857; aluminum tablet stamped " $882 " \ldots \ldots \ldots \ldots \ldots \ldots \ldots$. . . . . .

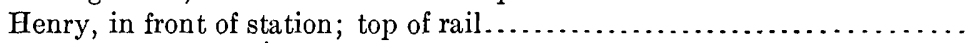

Henry, 0.5 mile north of, near end of first curve north of station, 25 feet west of tracks, 200 feet west of river; iron post stamped " 905 " . . . . . . . . . .

Henry, 3 miles north of, in northwest wing wall of concrete railway bridge 1849 , about 500 feet southwest of milepost 81 ; aluminum tablet stamped "1089"

761.566

797.387

904. 681 
Ferrum, 200 feet north of H. E. Menifee's store, 100 feet west of railway tracks, in vacant lot owned by H. E. Menifee, 2 feet west of fence and

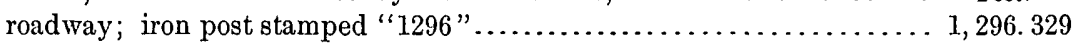

Ferrum, in front of station; top of rail..................... 1, 298. 1

Ferrum, 2 miles north of, in first masonry culvert north of station, 300 feet northeast of milepost 86 ; square cut....................... 196. 334

Waidsboro, 40 feet west of railway tracks, 10 feet north of public road, opposite south switch signal; iron post stamped " 1264 "................ 1, 263. 865

Saunders Siding, 60 feet east of railway track, opposite sign "Water 1 mile," 100 feet northeast of switch, opposite rear of Saunders's store; iron post stamped " 1084 ".

Rocky Mount, midway. between the Norfolk and Western and the Southern railways, near crossing, 500 feet southwest of milepost 94,200 feet southwest of Norfolk and Western station; iron post stamped " $1146 " \ldots \ldots \ldots 1,145.377$

Rocky Mount, in front of station; top of rail.................... 1, 146. 4

\section{LESLIE QUADRANGLE.}

ROCKY MOUNT, ALONG NORFOLK AND WESTERN RAILWAY, TO POINT 4 MILES SOUTU OF ROANOKE.

Rocky Mount, 1.8 miles east of, in southeast wing wall of concrete railway culvert 1828, about 700 feet northeast of sign "I mile to station;" alu-

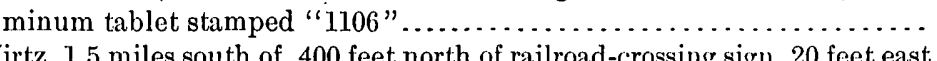

Wirtz, 1.5 miles south of, 400 feet north of railroad-crossing sign, 20 feet east of track, in first concrete culvert south of milepost 99 ; aluminum tablet stamped " 1067 "

Wirtz, 600 feet south of station, 50 feet of railway, 90 feet southeast of $A . J$. McNeil's store, 10 feet south of wagon road; iron post stamped "1128" . . 1, 127.878

Wirtz; in front of station; top of rail........................... 121.. 3

Boones Mills, 3 miles south of, 700 feet northwest of milepost 103, 503 feet southwest of road, in northwest abutment of trestle 181.9; aluminum tablet stamped "1131".

Boones Mills, 60 feet northeast of station; 40 feet south of wagon road, opposite store of C. W. Mills \& Co.; iron post stamped " 1128 ".......... 1, 127.915

Wright, 1 mile south of, 500 feet north of milepost 111, in west side of stone culvert; aluminum tablet stamped " 1171 ".................... 1, 170.567

Wright, 800 feet south of station, 500 feet south of milepost 110,20 feet east of track; iron post stamped " 1108 "........................ 1, 107.700

Starkey, 500 feet north of station, in east side of stone culvert, opposite water tank; square cut.................................. 1, 138. 579

Starkey, in front of station; top of rail....................... 138.7

Roanoke, 4 miles south of, 600 feet south of milepost 117, east side of stone

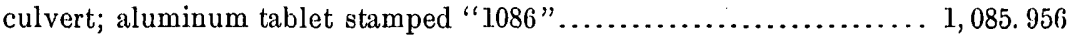

ROANOKE $\left(30^{\prime}\right)$ QUADRANGLE.

POINT 4 MILES SOUTI OF ROANOKE, ALONG NORFOLK AND WESTERN RAILWAY, TO LITHIA.

Roanoke, 1.5 miles south of, in southwest abutment of railway bridge over Roanoke River; aluminum tablet stamped " 937 ".................

Roanoke, in southwest corner of Hotel Roanoke grounds, near Shenandoah avenue and Jefferson street gate, 80 feet north of Jefferson street railway crossing; iron post stamped " 924 ".

936.680

Roanoke, in south abutment of First street viaduct, 270 feet west of Salem avenue, facing railway tracks; aluminum tablet stamped " 925 "....... 
Roanoke, in front of station; top of rail.

Hollins, 50 feet east of track, 40 feet southeast of station, near northwest corner of S. V. Nininger's yard; iron post stamped " 1169 ".......... 1, 168.954

Hollins, in front of station; top of rail.......................... 1, 165. 3

Cloverdale, in southwest corner of fenced right of way back of section tool house, 100 feet northwest of station, 10 feet north of wagon road; iron post stamped " 1133 " ....................................... 1, 132.435

Troutville, 2 miles south of, 500 feet north of milepost 9 , in northwest stone abutment of plate-girder bridge; aluminum tablet stamped " 1266 " ..... 1, 265.411

Troutville, in railway right of way opposite and 50 feet west of station, 6 feet west of telegraph pole; iron post stamped " 1405 "............. 1,404.598

Troutville, 270 feet north of station, 60 feet north of south switch, in west side of first stone culvert north of station; aluminum tablet stamped "1414"............................................... 1, 413:973

Troutville, in front of station; top of rail.................... 1, 407.7

Nace, 100 feet west of station, on railway right of way, 75 feet southwest of road crossing, 20 feet south of wagon road; iron post stamped " 1356 " ... 1, 356. 034

Nace, 2 miles north of, in southwest wing wall of iron railway bridge 411 over Back Creek; aluminum tablet stamped " $1170 " \ldots \ldots \ldots \ldots \ldots \ldots \ldots .1,169.900$

Lithia, in front of station; top of rail ...................... 982.0

Lithia, 90 feet west of railway tracks, opposite station, 10 feet south of east of J. W. Shirley's store, near fence corner; iron post stamped " 978 ".....

NATURAL BRIDGE SPECIAL QUADRANGLE.

BUCHANAN, NORTHWEST ALONG CHESAPEAKE AND OHIO RAILWAY, TO SALTPETRE CAVE.

Buchanan, 3 miles south of, 1,000 feet north of milepost 22 , near cattle guard, in east side of stone culvert; aluminum tablet stamped " 876 " .........

Buchanan, in front of Norfolk and Western Railway station; top of rail....

Buchanan, near southeast corner of Presbyterian Church on High street; iron post stamped " 862 "

978.058

Buchanan, in northwest abutment of wagon bridge near Chesapeake and Ohio Railway passenger station; aluminum tablet stamped " 832 "......

Buchanan, in front of Chesapeake and Ohio Railway station; top of rail...

Buchanan, in northwest abutment of wagon bridge near Chesapeake and Ohio Railway station; aluminum tablet stamped " 832 " .............

Buchanan, in front of station; top of rail..........................

Buchanan, 3.5 miles west of, at telegraph station; top of rail ............

Springwood, on northwest abutment of wagon bridge over James River; aluminum tablet stamped " 856 ".

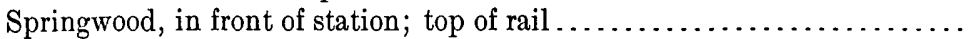

Springwood, 2.3 miles west of, northwest abutment of railroad bridge;

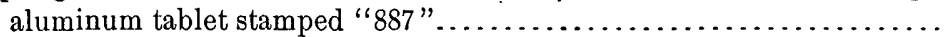

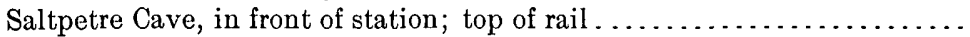

Saltpetre Cave, in southeast corner of east abutment at south side of railroad trestle over stream, 100 feet west of station; aluminum tablet stamped

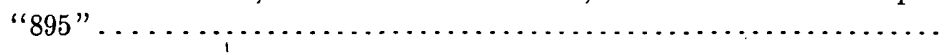

875. 355

883.3

861.394

831.854

829.8

831.854

831.1

849.2

855.628

851.8

887.550

895.8

894. 888

FINCASTLE QUADRANGLE.

SPRINGWOOD, ALONG CHESAPEAKE AND OHIO RAILWAY, TO GLEN WILTON.

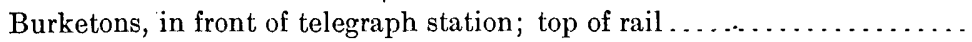

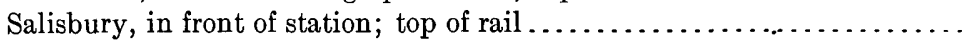

Salisbury, on northeast abutment of railroad bridge; aluminum tablet stamped " 913 ".

900.6

915.4

912.569 
Eagle Rock, in front of station; top of rail.

Feet.

Eagle Rock, 0.2 mile west of, on northwest abutment of wagon bridge; aluminum tablet stamped " 934 ".

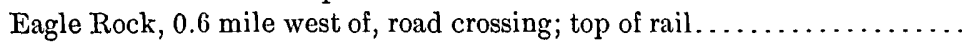

Eagle Rock, 1.8 miles west of, road crossing; top of rail.................

Gala, northwest abutment of railroad bridge; aluminum tablet stamped "954".

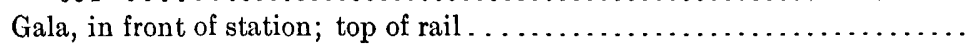

Gala, 1.9 miles west of, on east side of track, 60 feet southeast of switch; iron post stamped " 956 ".

932.0

934.550

936. 1.

939.0

954.414

955.6

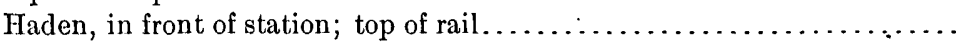

Haden, 1.4 miles west of, southeast abutment of railroad bridge; aluminum

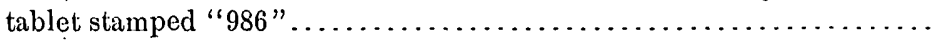

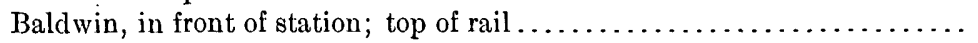

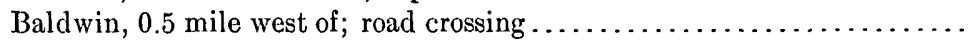

Baldwin, 2.2 miles west of, road crossing; top of rail..................

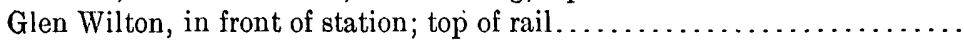

Glen Wilton, 70 feet from northwest end of station, west of private road, 4 feet from fence corner; iron post stamped " 997 " ................

955.872

962.3

985.930

987. 1.

983.6

991.6

999.4

CLIFTON FORGE QUADRANGLE.

996.251

LICK RUN, ALONG CUESAPEAKE AND OHIO RAILWAY, TO COVINGTON,

Lick Run, in front of station; top of rail...................... 1,003. 8

Lick Run, 0.6 mile west of, rock cut; aluminum tablet stamped "1017".. 1, 016. 584

Lick Pun, 1.1 miles west of, road crossing; top of rail . ............ 1.026. 3

Lick Run, 1.5 miles west of, Alleghany-Botetourt county line; top of rail. . 1, 025.54

Iron Gate, in front of station; top of rail .................... 028.7

Iron Gate, 0.3 mile west of, road crossing; top of rail .............. $1,030.9$

Clifton Forge, on railway bridge east of station, abutment; aluminum tab-

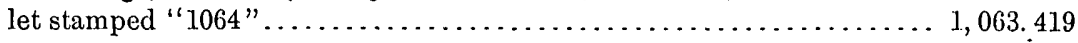

Clifton Forge, in front of station; top of rail.................

Clifton Forge, 3.3 miles west of, road crossing; top of rail . . . . . . . . 1, 127. 2

Clifton Forge, 3.3 miles west of, culvert; aluminum tablet stamped "11.27" 1, 126. 680

Lowmoor, in front of station; top of rail ..................... 1.45. 8

Lowmoor, 2.9 miles west of, south of track, in rock ledge; aluminum tablet

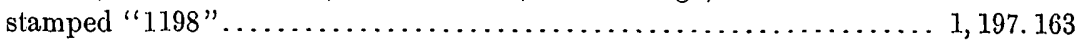

Lowmoor, 5.1 miles west of, in east abutment of railway bridge over river; aluminum tablet stamped " 1198 "...................... 1, 197.547

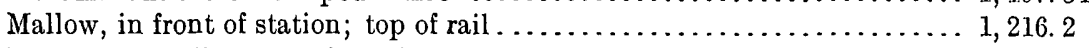

Mallow, 2.1 miles west of, road crossing; top of rail...................... $1,263.6$

Mallow, 3 miles west of, road crossing; top of rail.................. $1,246.5$

Covington, in front of station; top of rail . . . . . . . . . . . . . . . . .

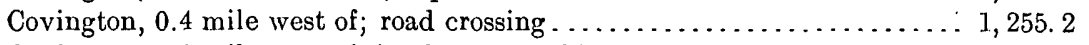

Covington, 0.6 mile west of, in abutment of iron railway bridge over river; aluminum tablet stamped " $1255 " \ldots \ldots \ldots \ldots \ldots \ldots \ldots \ldots \ldots \ldots \ldots \ldots \ldots \ldots \ldots \ldots ., 255.074$

LEWISBURg $\left(30^{\prime}\right)$ QUAdRANGle.

COVINGTON, ALONG CHEȘAPEAKE AND OHIO RAILWAY, TO ALLEGHANY.

Covington, 2.8 miles west of, on northwest abutment of railway bridge over river; aluminum tablet stamped " 1304 " ..................... 1, 303.896

Covington, 4.8 miles west of, in bridge abutment; aluminum tablet stamped

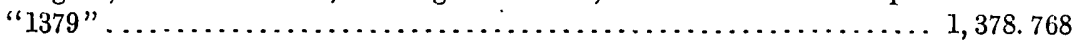


Callaghan, in front of station; top of rail........................ $1,425.9$

Moss Run, in front of station; top of rail...................... $1,575.2$

Moss Run, 0.9 mile west of, 396 feet west of milepost "Ft. M. 299," south side of track, in face of wall in rock cut; aluminum tablet stamped " 1599 ". 1, 598. 815

Backbone, in front of station; top of rail..................... 1,729. 6

Backbone, 380 feet west of, southeast foundation stone of water tank, north . side of track; aluminum tablet stamped " 1733 " ................ 1,733.079

Jerrys Run, in face of rock at rear of east end of station; aluminum tablet

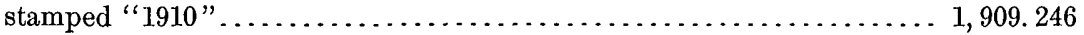

Jerrys Run, in front of station; top of rail..................... 1,906. 1

East Alleghany, in front of station; top of rail.................... 2,039. 7

Alleghany, 350 feet east of station, north face of east abutment of bridge under track; aluminum tablet stamped " 2049 " ................. 2, 047. 420

Alleghany, in front of station; top of rail . . . . . . . . . . . . . . . . . 070.6

\section{PRIMARY LEVELING.}

\section{Guilford and Snow Hill quadrangles.}

ACCOMAC COUNTY.

The elevations in the following list, based on tidal observations made by the Coast and Geodetic Survey at Franklin City, form part of a net of levels carried from Baltimore. (See Maryland list.) The leveling was done in 1900 by J. W. Hodges.

GUILFORD QUADRANGLE.

POCOMOKE CITY, SOUTH TO MASSEY.

Massey, at New Church station of the New York, Philadelphia, and Nor- Feet. folk Railroad; iron post stamped " 24 BALTO" $a \ldots \ldots \ldots \ldots \ldots \ldots \ldots \ldots . \quad 23.751$

SNOW HILL QUADRANGLE.

AT FRANKLIN CITY.

Franklin City, in front of post-office building, in foundation wall; bronze tablet stamped "4 BALTI"

Hampton, Isle of Wight, Jamestown, Toano, Williamsburg, and Yorktown quadrangles.

GLOUCESTER, ISLE OF WIGHT, JAMES CITY, SURREY, WARWICK, AND YORK COUNTIES.

The elevations in the following list are based on the latest adjusted heights along the Coast and Geodetic Survey precise-level line from Newport News. In crossing the James and York rivers, synchronous gage records were made for rising and falling tides.

The leveling in Toano, Williamsburg, Yorktown, and Jamestown, quadrangles was done in 1904 by T. A. Green; in Hampton quadrangle in 1906 by R. S. Deemer.

TOANO QUADRANGLE.

AT CROAKER.

Croaker, 25 feet east of road forks, directly south of post-office and store Feet.

kept by K. K. Tyssen; iron post stamped "107 ADJ 1903" .......... 107. 360 


\section{WILLIAMSBURG QUADRANGLE.}

WLLLIAMSBURG, NORTH ALONG HIGHWAY, TO CROAKER: THENCE NORTHEAST, CROSSING YORK. RIVER, TO SIGNPINE; THENCE SOUTHEAST VIA SASSAFRAS TO gLOUCESTER; THENCE SOUTH TO GLOUCESTER POINT.

Williamsburg, in east side of post-office, in fourth brick from northeast corner; aluminum tablet stamped "84 ADJ 1903 ".

Feet.

Williamsburg, 4.8 miles north of, at main road forks 1.3 miles west of Magruder post-office, just south of road forks on east side of road, at edge of Mr. Crest's farm; iron post stamped " 82 ADJ 1.903 "

84. 524

Oaktree, 2.1 miles northwest of, junction with main road, 1.4 miles northeast of Lightfoot, east side of road, just south of forks, on edge of William Maboul's farm; iron post stamped "115 ADJ 1903".

Croaker, 3.6 miles northeast of, south of York River, 0.2 mile north of mouth of Taskinas Creek, on ground of the Wilburg H. Davis estate, post is planted near southeast corner of kitchen of residence, on south side; iron post stamped "39 ADJ 1903"

West End, north of York River, west of road, 300 feet west of small creek, on Captain Coleman's estate, 75 feet south of house occupied by Moses Roe; iron post stamped " 3 ADJ 1903.

81.969

Signpine, 1.1 miles south of crossroads, west of oak tree standing in road; iron post stamped " 92 ADJ 1903 ".

Sassafras post-office, at southwest corner of crossroads, at northeast corner of north side B. C. Newcomb's store; iron post stamped "97 ADJ 1903"..

Gloucester, in fifth brick from northwest corner at west side of building owned and occupied by L. E. Mumford Banking Co., in tenth course of bricks above ground; aluminum tablet stamped " 76 ADJ 1903 ".......

Whitemarsh post-office, west of road, at junction with road running west, just north of forks, in southeast corner of J. R. Newcomb's store; iron post

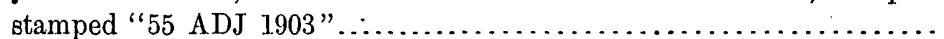

Ordinary post-office, 1 mile south of west of road, near southeast corner of W. H. Hoggs's store; iron post stamped " 39 ADJ 1904"............

YORKTOWN QUADRANGLE.

GLOUCESTER POINT, ACROSS YORK RIVER, TO YORKTOWN; THENCE SOUTHEAST, TO LEE HALL.

Gloucester Point post-office, at south side, near southwest corner of store kept by J. A. Taliaferro; iron post stamped "5 ADJ 1903 "...........

Yorktown post-office, 300 feet west of boat wharf, west of road, at corner of lot owned by R. W. Shields; iron post stamped "6 ADJ 1903"

Halsteads Point, 1.1 miles south of, east side of Lèbanon Church, in third brick from northeast corner, in tenth course of bricks above ground; aluminum tablet stamped " 82 ADJ 1903 ".....................

WILLIAMSBURG, SOUTHEAST ALONG CHESA PEAKE AND OHIO RAILWAY, TO DENBIGH.

G*:Tミ, on south side of post-office, near southeast corner; iron post stamped $\because \because$ ADJ 1903"

$\therefore \therefore$ e Hall, 1.9 miles southeast of, pumping station at reservoir, on east side of pump house, in south end of large stone forming doorsill of front entry;

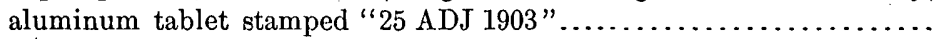

Denbigh, in fifth brick from northeast corner (east side) of brick courthouse, in tenth course of bricks above ground; aluminum tablet stamped

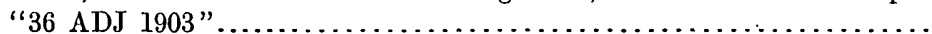


SPRINGFIELD, NORTHWEST, VIA SEPTA AND BACONS CASTLE, a TO HIGHGATE.

Septa, just southeast of road forks, on west side near south corner of postoffice and store kept by J. H. Edward; iron post stamped "86 ADJ 1903".

Septa, 3 miles northwest of, just south of Moonlight crossroads, west of road, on lot owned by W. L. Ward; iron post stamped "84 ADJ 1903"......

Septa, 5.3 miles northwest of, at junction with second-class road east, just south of forks, at northwest corner of lot owned by J. G. Goodrich, 25 feet southeast of Ferguson Grove Baptist Church; iron post stamped "92 ADJ 1903"

Bacons Castle, just south of crossroads on east side of road, near southwest corner of store and post-office; iron post stamped "84 ADJ 1903".

Highgate, at store and post-office at main forks of road; iron post stamped "75 ADJ 1903".

ISLE OF WIGHT QUADRANGLE.

NEWPORT NEWS, WEST ACROSS JAMES RIVER, TO BATTERY PARK; THENCE WEST TO SPRINGFIELD.

Battery Park, 25 feet south of boat wharf, at northwest corner (north side) of J. G. Wilson's store; iron post stamped "5 ADJ 1903"..............

Smithfield, in west side (second brick from north) of store owned by T. J. Cox, in seventeenth course of bricks above ground; bronze tablet stamped "Prim. Trav. Sta. No. 209-A 12".

\section{JAMESTOWN QUADRANGLE.}

HIGHGATE, NORTHWEST TO SCOTLAND; THENCE ACROSS JAMES RIVER TO JAMESTOWN; THENCE NORTHEAST TO WILLIAMSBURG.

Highgate, 2.2 miles northwest of, north of road just east of main forks, at southeast corner of store; iron post stamped "74 ADJ 1903 ".........

Scotland, at southeast corner'east side of store kept by Mrs. W. E. Adams; iron post stamped "7 ADJ 1903 ".

Jamestown, on land owned by the Association for the Preservation of Virginia Antiquities, at northwest corner of barn, on old church grounds; iron post stamped "9 ADJ 1903 ".

\section{HAMPTON QUADRANGLE.}

YORKTOWN, SOUTHEAST TO NEAR NORTH NEWPORT NEWS. (MEAN OF DIRECT AND REVERSE LINES.)

Yorktown, 3.1 miles southeast of, on Hampton-Yorktown road, at northwest corner of road southwest, 0.8 mile northwest of Harris Grove; iron post stamped " 65 ".

Grafton, 0.4 mile northeast of, south of Hampton-Yorktown road, 300 feet

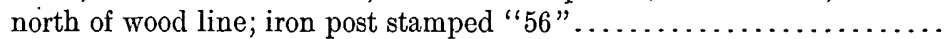

Kings Corners, 0.4 mile northeast of, 0.2 mile southwest of Zion Church

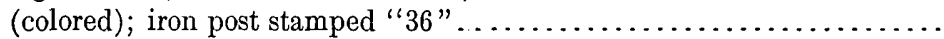

Moores Place, 0.1 mile southwest of, 0.4 mile east of Negro Bethel Church, east of Hampton-Yorktown road; iron post stamped " 31 "............

Little Bethel Church, on Yorktown-Hampton road, 5.5 miles northeast

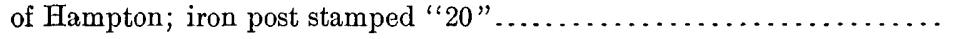

a An error of 1 foot between Battery Park and Scotland was adjusted arbitrarily by placing it south of Bacons Castle. 
NEAR NORTH NEWPORT NEWS, TO NEWPORT NEWS.

Newport News, 3.99 miles north of, road crossing Chesapeake and Ohio railway, southwest corner; iron post stamped " $30 " a \ldots \ldots \ldots \ldots \ldots$.

Feet.

29.441

POINT 6 MILES NORTH OF NEWPORT NEWS, SOUTHEAST VIA HAMPTON, TO OLD POINT COMFORT.

Hampton, 2 miles west of, on Hampton-Yorktown road, center of triangle (Newmarket Corners); iron post stamped " $11 " b . . . \ldots \ldots \ldots . . . . .$.

Appomattox $\left(30^{\prime}\right)$, Boydton, Callands, Chatham, Clarksville, Clover, Leslie, Lynchburg $\left(30^{\prime}\right)$, Moneta, Nathalie, and Virgilina quadrangles.

campbeli, charlotte, halifax, mecklenburg, and pittsyluania counties.

The elevations in the following list result mainly from a line of levels run in 1905 by A. H. Horton, of the water-resources branch, from a bench mark at Clarksville established by the precise-level party of R. L. Libby. The line follows Roanoke River (approximately) from Clarksville to Hurt; thence the railroad via Elba to Rocky Mount, where it is connected with a bench mark also established by Mr. Libby. A spur line extends 14 miles down Roanoke River from Clarksville, and another line extends from Toshes to Deerwood Ford.

Additional work was done in 1908 by E. O. Halbert, in cooperation with the State, in Clarksville, Clover, Nathalie, and Virgilina quadrangles, based on bench marks at Clarksville, Randolph, and Clarkton.

\section{CLARKSVILLE QUADRANGLE. ${ }^{c}$}

CLARKSVILLE, NORTHWEST ALONG ROANOKE RIVER, TO BAILEY'S PLANTATION.

Bluestone Creek, at mouth of, 250 feet north of Roanoke River, 120 feet east of Skipwith's (deserted) mill, top of low embankment; iron post stamped "284 ADJ 1903"

Feet.

283. 550

Abbyville, 1 mile below, in pasture lot of William Russell, 400 feet from river, in top of granite bowlder; aluminum tablet stamped " $290 \mathrm{ADJ}$ $1903 "$

289. 683

Abbyville, 2 miles above, on left bank of Roanoke River, at foot of bluff on McLean's plantation, 100 feet north of an old mill, set vertically in a granite ledge; aluminum tablet stamped " 296 ADJ 1903 ".

Abbyville, 5 miles above, 1,300 feet below mouth of Difficult Creek, which is on right bank of river, set vertically in a rock ledge on Bailey's plantation, on left bank of river; aluminum tabletstamped "312 ADJ 1903 "...

ClaRkSVILLE, WEST ALONG SOUTHERN RAILWAY, TO POINT 2 MLES WEST OF NELSON.

Clarksville, in southeast corner of west abutment pier at Southern Railway bridge; aluminum tablet stamped " 288 ".

Clarksville Junction, in front of station; top of rail.

Clarksville Junction, 200 feet west of, at railroad bridge; top of rail

South Clarksville, in front of station; top of rail....................

$a$ Not adjusted; closure on Coast and Geodetic Survey bench mark -0.496 foot.

o Not adjusted; closure on Coast and Geodetic Survey bench mark -0.501 foot.

$c$ For precise-level elevations in Clarksville quadrangle see p. 48. 
South Clarksville, 3 miles west of, 50 feet north of track, at west end of fill, inside of fence, in base of white-oak tree; spike.

Feet.

338. 80

South Clarksville, 1.2 miles west of, east end of small cut, sandstone bowlder 15 feet north of track; top marked "G.S. D376 B.M."

376. 20

South Clarksville, 2.2 miles west of, 300 feet north of track, in south face of chimney of George Day's $1 \frac{1}{2}$-story $\log$ house, 18 inches above ground;

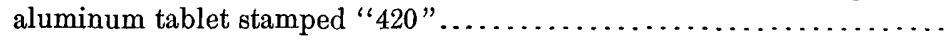

South Clarksville, 3.4 miles west of, 50 feet north of track, on public road, in root of large white-oak tree; railroad spike.

Buffalo Junction, in front of station; top of rail......................

Buffalo Junction, 1.1 miles west of, 120 feet south of railroad track south of public road, in foot of oak tree; spike.

Buffalo Junction, 2 miles west of, 200 feet south of railroad, in north face of chimney of H. T. Arrington's $1 \frac{1}{2}$-story house, 18 inches above ground;

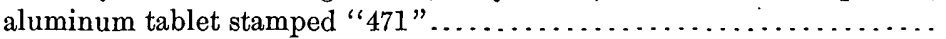

Buffalo Junction, 4.8 miles west of, top of brick railroad culvert, south head wall; aluminum tablet stamped " 423 ".....................

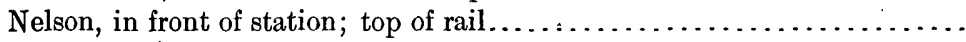

CLOVER QUADRANGLE.

DIFFICULT CREEK, NORTHWEST ALONG ROANOKE RIVER, TO CLARKS FERRY.

Lacks Ferry, 2 miles below, right bank of Roanoke River, 125 feet south of large double gum tree and large double white-oak tree, 250 feet from edge of river, 1 foot above line between properties of Alex. M. Coleman and Chas. Wadkins; iron post stamped "315 ADJ 1903".

315.265

Lacks Ferry, 1,100 feet above, on left bank of river, 50 feet from edge of river, in rock ledge; aluminum tablet stamped "323 ADJ 1903 "........

Beatrice, about 100 feet from former post-office; iron post stamped "479 ADJ 1903"

Beatrice, 3.4 miles northwest of, road forks at Black Castle schoolhouse; iron post stamped " 489 ADJ 1903 ".

Randolph; copper bolt in cement in capstone in left abutment downstream side of Southern Railway bridge across Roanoke River, stamped "341

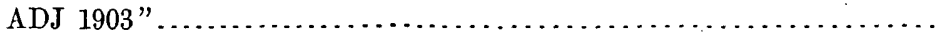

Clarks Ferry, 0.8 mile north of, in west side, near southwest corner of foundation of T. C. Watkins's house; aluminum tablet stamped " $453 \mathrm{ADJ}$

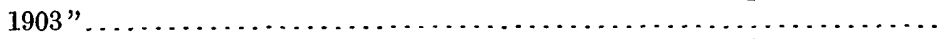

436.99

429.8

468.04

470.518

423.408

429.9

322.733

479. 368

489. 150

340. 657

452.562

RANDOLPH, SOUTHWEST ALONG SOUTHERN RAILWAY, TO POINT 1 MLE SOUTHWEST OF CLOVER.

Randolph; copper bolt in capstone in left abutment downstream side of railroad bridge across Roanoke River, stamped " 341 ".

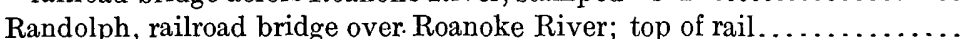

Surface of water under bridge over Roanoke River; September 30, 1908...

- Clover, in front of station; top of rail............................

Clover, in face of division wall between Bank of Clover and post-office, on west side of Main street; aluminum tablet stamped " 506 ".............

340.657

346.1

306

491.8

505.789

\section{NATHALIE QUADRANGLE.}

NEAR WATKINS, NORTHWEST ALONG ROANOKE RIVER, TO CLARKTON.

Watkins, 0.33 mile west of post-office, in southwest corner of four corners; iron post stamped " 490 ADJ 1903 "

Watkins, 1.2 miles west of, north of road, 100 feet northeast of I. C. Scott's mail box, corner of a stone post 1 foot above ground. 
Noland, north of road, 85 feet east of post-office and store; iron post stamped

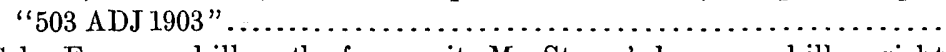

Feet. 503.070

Coles Ferry, on hill south of, opposite Mr. Stearn's house, on hill on right bank, in large bowlder embedded in ground; aluminum tablet stamped "401 ADJ 1903".

401. 429

Coles Ferry, 3 miles above, on north side of river road, on Bruce's estate near H. C. Gilliland's house; iron post stamped " 368 ADJ 1903"

Clarkton, in grass plot between Clark's store and station; iron post stamped "393 ADJ 1903".

HOUSTON, NORTH ALONG NORFOLK AND WESTERN RAILWAY, TO CLARKTON.

Neathery, in front of station; top of rail.

Neathery, 0.2 mile north of, 10 feet west of track, in top of west head wall of small stone railway culvert; aluminum tablet stamped " 482 ".

Neathery, 3.3 miles north of, 10 feet east of track, in top of east head wall of small stone railway culvert; aluminum tablet stamped " 534 ".......

Crystal Hill, in front of station; top of rail.......................

Crystal Hill, 1.9 miles north of, 200 feet south of road crossing, 10 feet west of track, in top of west head wall at small railway culvert; aluminum

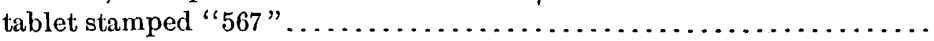

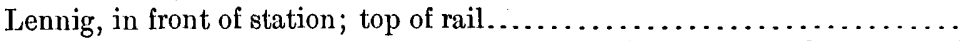

Lennig, 2.3 miles north of, 20 feet west of track, in top of west head wall of small railway culvert; aluminum tablet stamped " 531 " ............

Nathalie, in front of station; top of rail..........................

Nathalie, 1.8 miles north of, top of west head wall of small railway culvert; aluminum tablet stamped " 432 ".

Clarkton, in grass plot between Clark's store and station; iron post stamped "393 ADJ 1903"

564.3

566.731 .

576.7

530.543

524.5

431.738

386.434

SCOTTSBURG, NORTHEAST ALONG SOUTHERN RAILWAY, TO PONNT NEAR CLOVER.

Clover, 5 miles south of, 2,100 feet north of overhead bridge, top of west head wall of stone railway culvert; aluminum tablet stamped " 375 "....

Clover, 2.7 miles south of, top of east catch wall of south abutment of railway bridge; aluminum tablet stamped " 363 ".

LYNCHBURG $\left(30^{\prime}\right)$ QUADRANGLE.

PERTH, WEST ALONG ROANOKE RIVER, TO HURT.

McKeever Ferry, about 0.3 mile east of road forks, 75 feet south of T. L. Rudder's house, in a 3-foot turkey-oak tree; aluminum tablet stamped "545 ADJ 1903".

Green Hill, at road forks to ferry; iron post stamped " 510 ADJ 1903 ".....

Cedar Forest, 150 feet east of Mrs. E. Hendrick's store, at corner of fence; iron post stamped "540 ADJ 1903 "

Cedar Forest, 3 miles northwest of, south of road, opposite Blackstock schoolhouse, in a 3-foot oak tree; aluminum tablet stamped "702 ADJ $1903 "$

Level Run, 2 miles northeast of, at road forks near J. B. Moses farm; iron post stamped "704 ADJ 1903"

545.008

509.961

539.844

701. 952

703. 894

Level Run, north of road opposite post-office, in a 2-foot oak tree; aluminum tablet stamped "719 ADJ 1903 "

Level Run, 3 miles northwest of, about 200 feet south of Sandy Coleman's house, on Hubbard's plantation, in rock ledge west of road; aluminum tablett stamped "694 ADJ 1903" 
Grit, in road in front of A. M. Peak's house, in south side of a 4-foot whiteoak tree; aluminum tablet stamped "784 ADJ 1903 "

Feet.

783. 978

Grit, 2 miles northwest of, in forks of road at top of hill above mill creek ford; iron post stamped "728 ADJ 1903"

727.702

Hurt, 0.5 mile east of, in a $2 \frac{1}{2}$-foot oak at top of hill west of Reed Creek, south of road on Doctor Adams's plantation; aluminum tablet stamped "710 ADJ 1903"

Hurt, in right abutment (upstream side) of Southern Railway bridge; top of southwest bolt fastening upstream and post seat to abutment..........

HURT, SOUTH ALONG SOUTHERN RAILWAY, TO POINT NEAR ELBA.

Hurt, in ground at east post of "Welcome" gate at Hurt's plantation; iron post stamped "559 ADJ 1903 "

Motley, 2 miles north of, on west side of railroad about 30 feet from track, between mileposts 201 and 202, in a 4 -foot oak; aluminum tablet stamped "658 ADJ 1903"

Motley, in ground at G. W. Shuler's store, at east corner; iron post stamped "771 ADJ 1903"

Sycamore, 0.25 mile south of station, in north side of north chimney of G. W. Ramsey's house; aluminum tablet stamped "751 ADJ 1903" ..........

Elba, 3 miles north of, on west side of road from Elba to Sycamore, 600 feet south of railroad crossing, on east side of track, directly opposite Walton's mail box; iron post stamped "853 1903".

Elba, 2 miles north of, east of railroad, near first sign "Station 1 mile" referring to Elba, in a tree; aluminum tablet stamped "864 ADJ 1903"..

864. 126

CHatham QUADRANGLe.

ELBA, WEST ALONG SOUTHERN RAILWAY, TO TOSHES.

Elba, 150 feet north of Mrs. Shelton's store, at southeast corner of Mrs. E. W. Shelton's ground; iron post stamped " 844 ADJ 1903 ".............

Farmers, at northwest corner of E. H. L. Farmer's house, east of railroad, 60 feet from track; iron post stamped "1044 ADJ 1903".

Pittsville, 1 mile east of, in ground at road forks; iron post stamped "965

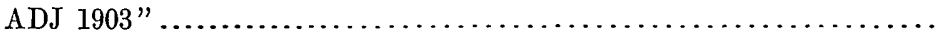

Toshes, 1,500 feet east of, in railroad cut east of Toshes, 140 feet west of west end of trestle across Buck Branch, tributary to Fryingpan Creek, south of railroad, at east end of rock ledge; aluminum tablet stamped "681 ADJ 1903"

Toshes, 125 feet south of post-office and store (property of C. S. Bennett), 25 feet east of scale house, in rock ledge; aluminum tablet stamped " 695 ADJ 1903"

MONETA QUADRANGLE.

TOSHES, ALONG HIGHWAYS TO DEERWOOD FORD (SPUR LINE).

Pig River, 1 mile south of bridge across, south of road, 0.25 mile above Graves's new dam on Pig River, in 4-foot white oak; aluminum tablet stamped "625 ADJ 1903 ".

624.38

Menla, about 1.5 miles southeast of, directly east of Frank Graves's house, 50 feet below his mail box, in east side of a 3 -foot oak tree; aluminum tablet stamped "734 ADJ 1903"............................

Menla, in front of J. T. Robinson's house, west of road, on east side of 4-foot oak tree; aluminum tablet stamped "862 ADJ 1903". 
Deerwood Ford, on Roanoke River, in northeast stone chimney of G. L. English's house; aluminum tablet stamped "618 ADJ 1903"..........

Deerwood Ford, on sycamore tree on left bank of Roanoke River near transit station $2681+15$; Virginia Railway bench mark............

Feet.

620.87

601.62

\section{CALLANDS QUADRANGLE.}

TOSHES, WEST ALONG SOUTHERN RAILWAY, TO GLADE HILL.

Sandy Level, in quartz ledge near road crossing of Reddies Creek; aluminum tablet stamped "660 ADJ 1903 ".

Ajax, 12 feet south of track, 450 feet west of crossing, east side of ledge of rock; aluminum tablet stamped "873 ADJ 1903 ".

Penhook, 500 feet west of station, 8 feet south of track, in rock ledge; aluminum tablet stamped " 982 ADJ 1903 ".

Novelty, in ground at angle of store (former post-office); iron post stamped "1009 ADJ 1903".

Union Hall, in north face of chimney of Dudley \& Co. store; aluminum

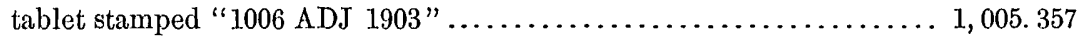

Glade Hill, 1.5 miles east of, in east side of south chimney of Mrs. Matilda Bird's house, north of track, 350 feet from track; aluminum tablet stamped " 1008 ADJ 1903 "................................. 1., 007. 352

Glade Hill, in a 3-foot chestnut oak, 100 feet east of former post-office, 65 feet south of track; aluminum tablet stamped "1070 ADJ 1908"...... 1, 069.611

LESLIE QÜADRANGLE.

GLADE HIL,, WEST ALONG SOUTHERN RAILWAY, TO ROCKY MOUNT.

Red wood, 2 miles east of, 1.25 feet north of track on Jas. O. Perdies's farm, 30 feet west of west end of second trestle west of Glade Hill, on left bank of small branch, in lower of two small rock ledges; aluminum tablet stamped "1060 ADJ 1903 ".

Redwood, in small rock ledge in front of Perdies Brothers' store; aluminum

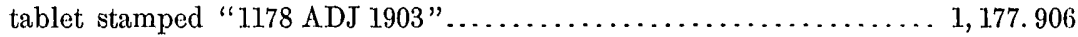

Redwood, about 0.5 mile west of, 300 feet west of railroad crossing, 30 feet south of track, in east end of a large quartz bowlder north of road; aluminum tablet stamped "1138 ADJ 1.903"

Rocky Mount, 2.5 miles east of, 1,200 feet west of milepost 34, 75 feet west of railroad crossing, 9 feet south of center of track; iron post stamped "1193 ADJ 1903".

Rocky Mount, 1.8 miles east of, in southeast wing wall of Norfolk and Western Railway concrete culvert 1828, about 700 feet northeast of sign "1 mile to station;" aluminum tablet stamped "1106 ADJ 1903"..... 1, 106. 274

\section{BOYDTON QUADRANGLE.}

CLARKSVILLF, EAST 14 MILES DOWN ROANOKE RIVER, TO TAYL,ORS FERRY (DOUBLE SPUR LINE).

Clarksville, 2.5 miles below, on right bank of river on C. S. Hito's plantation, about 340 feet from bank of river, in granite ledge on left bank of a small ditch; aluminum tablet stamped " 273 ADJ 1903 ".............

Clarksville, 7 miles below, opposite J. T. Lewis's plantation; opposite lower end of Finches Island, in granite ledge projecting from left bank of river; aluminum tablet stamped " 250 ADJ 1903 "

Island Creek, 215 feet from right bank, 300 feet from river, in a granite ledge on James Bulloch's plantation; aluminum tablet stamped " 259 ADJ 1903" 
Eagle Point, 1,500 feet east of ruins of mill, at foot of slope, 100 feet below Hospital Spring on Doctor Wimbish's plantation, in granite ledge; aluminum tablet stamped " 239 ADJ 1903 "

Feet. 239.337

\section{APPOMATTOX (30') QUADRANGLE.}

BROOKNEAL, TO PERTH.

Brookneal, on east side of road to ferry, nearly opposite May's cash store, about 75 feet north of Baptist Church; iron post stamped "564 ADJ $1903 "$.

564.155

Brookneal, on William Scott's plantation, 135 feet northwest of center of road to ferry, 50 feet from low-ground cornfield, about 350 feet north from ferryman's house at ferry, in rock ledge flush with ground; aluminum tablet stamped "388 ADJ 1903".

Brookneal, 2.3 miles southwest of, about 20 feet from northwest corner of Hickory Road Church, in an 18-inch oak tree; aluminum tablet stamped "599 ADJ 1903".

Perth, 225 feet northeast of store and former post-office, south of road, on W. H. and J. L. Glass's property; iron post stamped "612 ADJ 1903"...

VIRGILINA QUADRANGLE.

VIRGILINA, WEST ALONG SOUTHERN RAILWAY, TO DENNISTON; THENCE NORTH ALONG NORFOLK AND WESTERN RAILWAY, TO HOUSTON.

Virgilina, in front of station; top of rail.

516.1

Christie, in front of station; top of rail.

Mayo (3.8 miles west of Christie), 300 feet east of station, top of east head wall of concrete railway culvert; aluminum tablet stamped " 346 "......

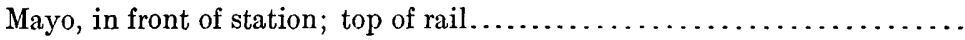

Mayo, 1.9 miles west of, in southwest corner of east abutment of railway bridge over Hyco Creek; aluminum tablet stamped " 336 "...........

Denniston, 50 feet north of Norfolk and Western Railway station, in top of east head wall of small concrete railway culvert; aluminum tablet stamped " 409 ".

Cluster Springs, 300 feet west of station, in front (brick) wall of Traynham Brothers' store; aluminum tablet stamped " 499 ".................

Cluster Springs, in front of station; top of rail:.

Cluster Springs, 3.5 miles north of, 5 feet east of track, in top of head wall of small concrete railway culvert; aluminum tablet stamped " 339 ".......

South Boston, railway bridge over Dan River; top of rail..............

Water in Dan River under bridge; surface September 17, 1908..........

South Boston, in northeast corner of north abutment pier at Norfolk and Western Railway bridge over Dan River; aluminum tablet stamped "331"

South Boston, in front of station; top of rail

345.649

344.9

335.497

409.449

499. 446

493. 3

339.249

336.6

302

330.976

South Boston, 3.4 miles north of, 15 feet east of track, top of east head wall at small stone railway culvert; aluminum tablet stamped " 447 ".......

Houston, in front of station; top of rail...........................

Houston, 0.7 mile north of, 20 feet west of track, in top of west head wall of small railway culvert; aluminum tablet stamped " 381 " ..............

SOUTH BOSTON, NORTHEAST ALONG SOUTHERN RAILWAY, TO SCOTISBURG.

South Boston, in front of station; top of rail.

447.153

385.6

380.827

333.4

Wolftrap, 1.8 miles south of, 800 feet south of milepost 34 , in top of southeast corner of east head wall of stone railway culvert; aluminum tablet stamped " 318 ". 
Wolftrap, in front of station; top of rail

Scottsburg, 1.7 miles south of, 10 feet west of track, 300 feet north of whistle post, in top of west head wall of small concrete railway culvert; aluminum tablet stamped " 331 .".

Scottsburg, in front of station; top of rail.

Fincastle and Natural Bridge special quadrangles.

BOTETOURT AND ROCK BRIDGE COUNTIES.

The elevations in the following list are based on an aluminum tablet set in the west end of north abutment of wagon bridge over James River at Buchanan, the elevation of which is accepted as 831.854 feet above mean sea level. This elevation was obtained from $a$ line of precise levels run from Greensboro, N. C., to Buchanan in the summer of 1905 by R. L. Libby. The leveling was done in 1905 by T. A. Green.

NATURAL BRIDGE SPECIAL QUADRANGLE.

BUChaNAN, NORTHEAST ALONG CHESAPEAKE AND OHIO RALWAY, TO GILMORE MILLS.

Buchanan, 3.3 miles northeast of, 200 feet east of house occupied by Charles Stinnett, in ledge of rock; aluminum tablet.

Feet.

818.701

Dillon, in front of station; top of north rail of main track..............

Indianrock, in southeast corner of wast abutment at south side of railway bridge over Whistle Creek; aluminum tablet......................

Indianrock, in front of station; top of north rail of main track...........

Rocky Point, in southeast corner of east abutment of railroad bridge over

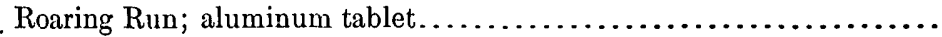

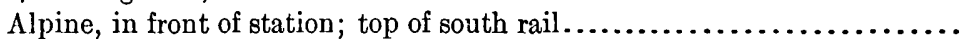

Gilmore Mills, in front of station; top of north rail..................

794. 164

795. 9

771. 149

773.6

751.1

GILMORE MILLS, NORTH ALONG HIGHWAY, VIA NATURAL BRIDGE AND LONGWOOD, TO MURAT.

Natural Bridge, on north side of bridge, in rock standing in inclosure; aluminum tablet stamped "1150 ADJ 1903" .................. 1, 149.661

Natural Bridge, 2.6 miles northeast of, at main road forks 1.5 miles southwest of Fancy Hill post-office, in rock north of road just east of forks; aluminum tablet stamped "1231 ADJ 1903"................... 1, 231. 014

Longwood, 1 mile northeast of, in fifth brick from west at southwest corner (south side) of Seceder Church, in fourth course of bricks above foundation; aluminum tablet stamped "1179 ADJ 1903".

Longwood, 3.8 miles northeast of, 75 feet south of stream crossing, in large rock; aluminum tablet stamped "1251 ADJ 1903".............. 1, 250.677

Murat, in southeast corner of south abutment of south end of highway bridge over Buffalo Creek; aluminum tablet stamped "1021 ADJ 1903"....... 1, 021.262

BUCHANAN, NORTH ALONG HUGHWAYS, VIA RAPPS MILL, TO MURAT.

Buchanan, 3 miles north of, on Mr. Peachin's place, in sandstone 75 feet north of house occupied by Charles Miller; aluminum tablet........... 1, 161. 841

Buchanan, 7 miles north of, at main road forks just west of Dunkard Church in rock on east side of road just north of forks; aluminum tablet stamped

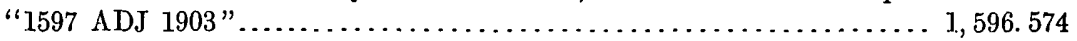

Rapps Mill, 50 feet southeast of, in front yard of James B. Rapp, in sandstone; aluminum tablet stamped "1497 ADJ 1903" 
Rapps Mill, 3.2 miles northeast of, 210 feet north of main forks, in ledge of Feet. rock east of road; aluminum tablet stamped "1277 ADJ 1903" ....... 1, 277. 262.

Murat, 3.5 miles west of, 6.2 miles northeast of Rapps Mill, at iron wagon bridge over South Buffalo Creek, on south side at southeast corner of east abutment; aluminum tablet stamped "1150 ADJ 1903"............ 1, 149.707

UP NORTH BUFFALO CREEK, VIA OAKDALE AND OVER BIGGS MOUNTAIN, TO DAGGER SPRINGS AND GALA.a

Oakdale, 1.5 miles southwest of, north of road, in rock 30 feet west of main road forks; aluminum tablet stamped "1307 ADJ 1903"............ 1, 308.004

Oakdale, 6 miles southwest of, at gap at head of North Buffalo and Mill Creek, in large bowlder; aluminum tablet stamped "2179 ADJ 1903".. 2, 179. 680

Oakdale, 9.8 miles southwest of, at crossroads, 2 miles southeast of Dagger Springs, directly north of 4 corners, in rock north of road; aluminum tablet stamped "1392 ADJ 1903 "........................... 1, 392.463

FINCASTLE QUADRANGLE.

SPRINGWOOD, WEST ALONG HIGHWAY, TO FINCASTLE.

Springwood, 5.1 miles southwest of, on north side at northwest corner of stone foundation of house owned by C. C. Burch; aluminum tablet.... 1, 284.070

Fincastle, 10 feet west of front entrance of court-house, in stone step on south side of building: aluminum tablet....................... 1,256. 696

Fincastle, 4.4 miles northwest of, at mouth of Poorhouse Hollow, 650 feet west of main forks, on north side of North Fork of Catawba Creek, east of second-class road; in limestone ledge; aluminum tablet.

$1,255.379$

Middletown, Mount Vernon, and Seneca quadrangles.

LOUDOUN AND FAIRFAX COUNTIES.

The elevations in the following list are based on precise-level lines of the Coast and Geodetic Survey and the Baltimore and Ohio Railroad.

The leveling in Seneca and Mount Vernon quadrangles was done in 1906 by R. A. Farmer; and in Middletown quadrangle in 1907 by W. R. Winstead.

Elevations in Maryland appear on pages 34 and 35 ; those in West Virginia have been published in Bulletin 399.

MIDDLETOWN QUADRANGLE.

POINT OF ROCKS, SOUTHWEST ALONG HIGHWAY, TO TAYLORSTOWN; TUENCE NORTHWEST TO IIARPERS FERRY.

Taylorstown, 0.1 mile west of post-office, in center of south end of pillar at west end of iron bridge over Catoctin Creek; aluminum tablet stamped

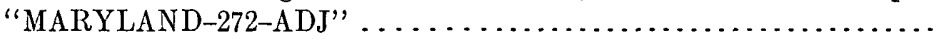

Feet. 272. 190

Taylorstown, 2.6 miles northwest of, 50 feet east of road fork south, near short bend in road to north, 15 feet west of barn, on top of stone; chiseled square marked " 479.6 -U.S.B.M.".............................

Lovettsville, in front face of post-office at G. F. Eamich's store, east side of door, between door and window; aluminum tablet stamped "MD-507ADJ" .

506.990

a $Q$ ne fogt arbitrary adjustment was made between starting point and first bench mark of this line. 
Lovettsville, 3.4 miles northwest of, 0.1 mile north of road fork, 150 feet north of second-class fork west, 1,000 feet east of house, 8 feet east of road by fence bars, in west side of large sandstone; aluminum tablet stamped

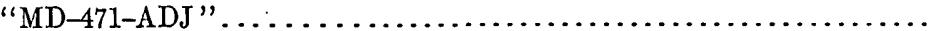

Lovettsville, 7.1 miles northwest of, 0.4 mile west of sawmill, about 0.2 mile west of old house, at spring on left of road in front of house, 12 feet north of road between road and river, in top of large native rock; aluminum tablet stamped "ADJ 254 ".

Lovettsville, 8.7 miles northwest of; nail in north side at center of bridge over Shenandoah River at Harpers Ferry, marked " 281 "........... PONNT 1 MILE EAST OF HARPERS FERRY, SOUTH TO NEERSVILLE.

Neersville, 300 feet north of road forks, 0.2 mile north of former post-office, in northeast corner of schoolhouse; aluminum tablet stamped " $615 \mathrm{ADJ}$ ".

SENECA QUADRANGLE.

EDWARDS FERRY, SOUTHEAST TO DRANESVILLE.

Mahala, 50 feet north of former post-office, north of pike, in big flat rock; tablet stamped " 326 ".

Daysville, J. T. Palmer's house, in south wall of west chimney; tablet

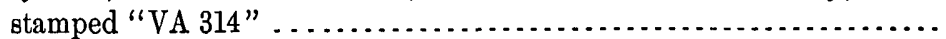

313. 950

MOUNT VERNON QUADRANGLE.

DRANESVILLE, EAST TO GREAT FALLS.

Dranesville, 0.25 mile east of; opposite J. F. Duke's house, south of pike, 12 feet east of 30 -inch oak tree at road forks, in 20 by 8 by 8 inch rock; tablet stamped "Va. 395".

Forestville, near southeast corner of east foundation of Oliver's store; tablet stamped " 348 VA".

\section{Pocahontas quadrangle.}

\section{TAZEWELL COUNTY.}

The elevations in the following list are based on the height of permanent bench mark at Graham, established by precise leveling in 1909. The leveling was done by T. A. Green in 1909. Elevations in this quadrangle in West Virginia are not included in this bulletin.

DIVIDE AT HEAD OF ABBS VALLEY, SOUTHWEST TO SMITH STORE; THENCR NORFH TO STATE LINE (PART OF ADJUSTED CIRCUIT).

Smith store, 350 feet south of forks, 75 feet east of road, 200 feet west of Mrs.

W. T. Harrison's barn, on west side of running stream, in sandstone; alu- Feet.

minum tablet stamped "2598 VA 1909" . . . . . . . . . . . . . . . . . . 2, 597.895

STATE LINE, SOUTHEAST ALONG NORFOLK AND WESTERN RAILWAY, TO GRAPAM.

Virginia-West Virginia state line, railway crossing; top of rail.......... 2,309.4

Flattop, 0.8 mile east of, on rock 40 feet east of milepost 370 ; chiseled square. $2,321.20$

Falls Mills, in front of station; top of rail....................... 2,330. 1

Falls Mills, 1.5 miles east of, 500 feet west of milepost 368 , north end of east abutment of railroad bridge 840 ; aluminum tablet stamped " 2348 " .... 2, 347. 640

Falls Mills, 2.8 miles east of, at old sawmill, 100 feet east of road crossing on north end of west abutment of iron railroad bridge 835 ; chiseled square. . 2, 370. 10

Graham, in front of signal tower; top of rail................... 2,386.2 53492 -Bull. $434-10-5$ 
Graham, at northwest corner of station plätform; on granite curbing; chis- Feet.

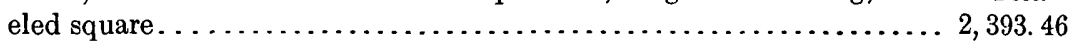

Graham, on west side of front entrance to Bank of Graham, third step above pavement; aluminum tablet stamped " $2389 " \ldots \ldots \ldots \ldots \ldots \ldots \ldots ., 389.450$

STATE LINE, SOUTHWEST ALONG NORFOLK AND WÉSTERR RALWAY, TO POCAHONTAS (MEAN OF TWO LINES).

Pocahontas, in front of station; top of rail. .................... 318.8

Pocahontas, on west side of front entrance to Bank of Pocahontas, in first step above pavement; aluminum tablet stamped " $2320 \mathrm{VA} 1909$ " ........2, 320.057

STATE LINE NEAR NEMOURS, W. VA., SOUTHWEST UP ABBS VALLEY TO POINT NEAR DIVIDE

(PART OF ADJUSTED CIRCUIT).

Nemours, 1.1 miles southwest of, east of road, 20 feet west of gate, on limestone; chiseled square marked "U.S.B.M. 2334 "............... 2,330.78

Nemours, 1.9 miles southwest of, west of road, at top of knoll, on limestone; chiseled square marked "U.S.B.M. 2395 " . .................. 2, 395. 18

Nemours, 2.8 miles southwest of, at road forks, 300 feet east of large red barn, 30 feet north of gate east of road, in limestone; aluminum tablet stamped " 2443 VA 1909 ".

Nemours, 4 miles southwest of, 300 feet south of Mr. Browning's house, west of road, at sharp bend, on limestone ledge; chiseled square marked "U.S.B.M. 2411".

Nemours, 4.9 miles southwest of, at junction with main road running east, 15 feet west of telephone pole at northeast corner of road junction, on limestone; chiseled square marked "U.S.B.M. 2441."............ 2, 441. 27

Nemours, 6.4 miles southwest of, south of road, on top of hill, north of fence, in sandstone bowlder; aluminum tablet stamped "2523 VA

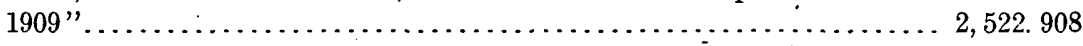

Nemours, 7.5 miles southwest of, 0.3 mile southwest of J. G. Bailey's, north of road, on limestone outcrop; chiseled square marked "U.S.B.M. 2517". 2, 516. 72

Nemours, 8.3 miles southwest of, at junction with road running northwest, through gate, point on limestone, 5 feet north of W. A. Barrett's mail box, at southeast corner of road junction; mail box marked "U.S.B.M. $2529 "$.

$2,528.92$

SMITH STORE, NORTH TO STATE LINE (PART OF ADJUSTED CIRCUIT).

Smith store, 1.5 miles northwest of, south of road, 50 feet west of sharp bend, on sandstone outerop; chiseled square marked "U.S.B.M. 2601 "...... 2, 601.26

\section{Middlesboro quadrangle.}

LEE COUNTY.

The elevations in the following list were determined by a double line of primary leveling brought from a precise-level bench mark near Mascot, Tenn., to Cumberland Gap and thence by a single spur line to Wheeler. The leveling was done by F. L. Foust in 1903. Elevations in Kentucky and Tennessee äre not included.

COMBERLAND GAP, EAST ALONG LOUISVILLE AND NASHVILLE RAILROAD, TO WHEELER.

Cumberland Gap, at summit, on Kentucky-Tennessee-Virginia stone Feet. corner post; chisel point.............................., 648.47

Wheeler, 0.3 mile northeast of station, 75 feet south of switch stand, in southeast corner of large stone culvert; bronze tablet stamped " 1256 LEXINGTON"..................................... 256.465 
Abingdon quadrangle.

GRAYSON, RUSSELL, SMYTH, AND WASHINGTON COUNTIES.

The elevations in the following list were deternined in 1908 and 1909 by J. B. Metcalfe, jr., by a single unchecked line from a point 0.3 mile northeast of Housley, Tenn., in Roan Mountain quadrangle to Damascus, Va. Other lines are closed circuits dependent on this line.

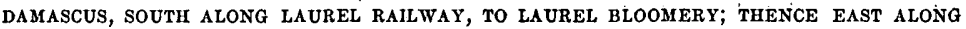
HIGHWAYS TO LITTLE HORSE CREEK; THENCE NORTH TO POINT 3.1 MILES NORTHEAST OF KONNAROCK.

Little Horse Creek, 4.7 miles north of, near junction of Big Horse Creek and Mud Fork, near Bill Miller's house, 10 feet east of road, 20 feet northeast of forks, in ledge of rock; aluminum tablet stamped " 2954 ".

Little Horse Creek, 8.5 miles north of, 8 feet east of road, 300 feet northwest of old house; cross on ledge of rock, marked " 3984 ".

Little Horse Creek, 10.2 miles north of, about 0.25 mile from top of gap between Whitetop and Rogers mountains, 60 feet south of second-class road forks to southwest, 6 feet west of road; cross on ledge of rock, marked " 4535 "

Little Horse Creek, 10.2 miles north of, about 0.25 mile from top of gap between Whitetop and Rogers mountains, about 60 feet south of secondclass road fork to southwest, about 7 feet west of road, in ledge of rock; aluminum tablet stamped " 4535 "

Konnarock, 6.8 miles northeast of, about halfway up mountain road, over gap between Whitetop and Rogers mountains, east of road; nail in root of chestnut tree, marked " 4102 "........................... 4, 101.2

DAMASCUS, NORTHWEST ALONG VIRGINIA-CAROLINA RAILWAY, TO ABINGDON.

Damascus, 2.4 miles northwest of, 20 feet west of railroad, 100 feet south of milepost $\mathrm{A13}$, in ledge of limestone rock; aluminum tablet stamped "1834".

Baron station, about 0.5 mile southeast of, 8 feet north of railroad, 35 feet west of milepost A9, in limestone rock; aluminum tablet stamped "1763" 1, 762.700

Watauga, 1 mile northwest of, 10 feet west of railroad, 260 feet north of bridge No. 3 over creek, in ledge of rock in cut; aluminum tablet stamped "1924".

Abingdon, south side of southeast corner of new building being put up by Mr. Sumner, about 3.5 feet from ground and 2 feet from east corner of same, facing on Main street, and 200 feet northeast of confederate monument, in brick wall; aluminum tablet stamped " 2096 " .......... 2, 095. 386

ABINGDON, EAST ALONG NORFOLK AÑD WESTERN RAILWAY, TO MARION.

Abingdon, 3.8 miles east of, 10 fèet north of railroad, 12 feet east of milepost "B-19 N-389," 50 feet east of cross roads, in rock; aluminum tablet stamped " 2167 "

Meadow View, 1,030 feet west of station, 12 feet north of railroad, on north end of culvert over small creek, in rock; aluminum tablet stamped " $2110 "$ ".

Emory, 2.2 miles east of, 20 feet south of railroad, southeast corner of stone culvert, 40 feet north of road, running parallel to railroad, 1,450 feet east of mile post "B-26 N-382," in top of rock; aluminum tablet stamped "2083". 
Wimory, 6.6 miles east of, 10 feet south of railroad, on southwest corner of culvert, 1,950 feet east of milepost "B-31 N-377," in rock; aluminum tablet stamped " 2047 "

Feet.

Chilhowie, 0.8 mile east of, 6 feet south of railroad, on southwest abutment of railroad bridge over Middle Fork, Holston River, in top face of abutment; aluminum tablet stamped "1950"....................... 1, 949. 456

Chilhowie, 2 miles east of, 10 feet east of bridge over Middle Fork, Holston River, on joint of south rail of railroad; marked "1964"............ 1,963. 61

Chilhowie, 3.5 miles east of, 7 feet north of railroad, about 1 mile east of Sevenmile Ford, on northeast corner of abutment to trestle over Middle Fork, Holston River, also to arch over road, in top face of abutment;

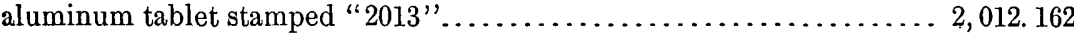

Marion, 8 feet north of railroad, about 0.25 mile west of station, on top face of abutment to bridge over Middle Fork, Holston River; cross on top of rock, marked " $2126.7 . " \ldots \ldots \ldots \ldots \ldots \ldots \ldots \ldots \ldots \ldots \ldots \ldots \ldots \ldots . .2,126.04$

Marion, on west side of station, 1 foot south of northwest corner and 4 feet from ground, in brick wall; aluminum tablet stamped " 2145 " ......... 2, 144. 624

DAMASCUS, EAST ALONG VIRGINIA-CAROLINA RAILWAY, TO POINT 3.1 MLES NORTHEAST OF KONNAROCK.

Damascus, 0.2 mile west of station, south side of Main street, in east face of brick wall, 2.7 feet south of northeast corner of Bank of Damascus, 3.4 feet from ground; aluminum tablet stamped "1929"'.............. 1, 928. 344

Taylors Valley, 1,360 feet northwest of station, 7 feet east of railroad, in ledge of rock in cut; aluminum tablet stamped " 2366 " ............. $2,365.210$

Konnarock, 3,200 feet southwest of station, 10 feet north of railroad, in ledge of rock; aluminum tablet stamped " 2896 " ................... $2,895.695$

Konnarock, 3.1 miles northeast of, 12 feet north of road forks, on road to Chilhowie; nail in root of 4-foot red-oak tree, marked " 3138.5 "......... 3, 137.87

PONNT 3.1 MILES NORTHEAST OF KONNAROCK, NORTH ALONG HIGHWAYS, TO CHILHOWIE.

Konnarock, 3.7 miles northeast of, on road to Chilhowie, east side of road, south side of mountain; cross on ledge of rock, marked " 3187.3 " ....... 3, 186.61

Konnarock, 5 miles northeast of, on road to Chilhowie, on top of Skulls Gap, east side of road; nail in root of 2.5 -foot white oak tree, marked " 3659.8 ". $3,659.16$

Konnarock, 7 miles north of, on north side of mountain, east side of road; nail in root of $1 \frac{1}{2}$-foot red-oak tree, marked " 2975 " .............. 2,973.99

Konnarock, 9.4 miles north of, on road to Chilhowie, 35 feet east of road, 50 feet south of large spring with house over it, in limestone rock sticking out of bottom of hill; aluminum tablet stamped " 2240 " ............ 2, 239. 212

Konnarock, 12.2 miles north of, on road to Chilhowie, 10 feet east of road, 250 feet south of large white house on east side of road and red barn on west side, in ledge of limestone rock; aluminum tablet stamped " 2222 ". 2, 220.999

Konnarock, 13.7 miles north of, on road to Chilhowie, 30 feet east of road forks, 2 feet above level of road; cross on ledge of rock, marked "2097.2". 2, 096. 60

MARION, NORTH ALONG HIGHWAYS, TO CHATHAM HLL; THENCE WEST TO HAYTER GAP; THENCE SOUTH TO ABINGDON.

Marion, 2.5 miles north of, on road to Chatham Hill, in forks of road to west, near Mr. Copenhaver's house; cross on ledge of rock, marked " 2202 ". .. 2, 201. 43

Marion, 5.2 miles north of, on road to Chatham Hill, north side of mountain road, about 0.5 mile from bottom of same; cross on rock, marked

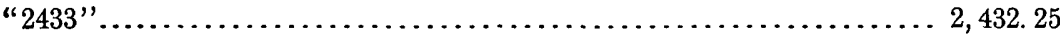

Marion, 6.2 miles north of, on road to Chatham Hill, east side of mountain road, just opposite old sawmill; cross on ledge of rock, marked " 2834 ".. 2, 833.53 
Marion, 7.8 miles north of, on road to Chatham Hill, 6 feet east of road, 300 feet north of where road crosses top of mountain, in ledge of rock; aluminum tablet stamped " 3454 ".

Marion, 10.5 miles north of, on road to Chatham Hill, 3 feet west of road and 300 feet west of large barn; cross on ledge of rock, marked " 2392.4 ". 2, 391.78

Chatham Hill, 1 mile west of, 250 feet south of road forks, 60 feet west of White Oak Branch, 6 feet west of road, in ledge of limestone; aluminum tablet stamped " 2050 ".

Chatham Hill, 2.7 miles west of, on road to Saltville, 6 feet west of road, 10 feet north of gate to field, at top of hill; cross on ledge of rock, marked " 2330.4 ".

Chatham Hill, 6.9 miles west of, 220 feet west of road forks, also 200 feet west of where Cove Creek crosses road and about 100 feet southeast of Cove Creek schoolhouse, 6 feet north of road, 4 feet above level of road, in ledge of limestone; aluminum tablet stamped " 1810 ".......... 1,808.841

Broad Ford, 1.2 miles west of, on road to Saltville, 6 feet north of road, 3 feet above level of road, in cut along North Fork Holston River, in slanting ledge of rock; aluminum tablet stamped " 1758 " ......... 1, 757. 782

Saltville, 3.9 miles east of, on road to Saltville, 175 feet west of road forks, about 0.5 mile east of Southern Gypsum works, 3 feet east of road; cross

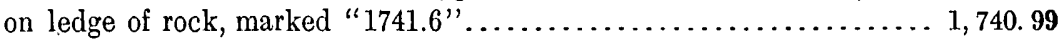

Saltville, 0.6 mile east of, 200 feet north of store at Cedar Branch, 8 feet north of road, on northwest abutment to bridge over North Fork Holston River, in top face; aluminum tablet stamped "1714"............. 1, 71.3. 111

Saltville, 2.3 miles west of, on road to Hayter Gap, 7 feet south of road forks and 45 feet northeast of house; cross on large rock, marked " 1926 " .... 1, 925. 34

Saltville, 5.1 miles west of, on road to Hayter Gap, 100 feet west of bridge over Tumbling Creek, in road forks north; cross on rock, markè " 1765 ". 1, 764. 09

Saltville, 5.8 miles west of, on road to Hayter Gap, 30 feet north of road forks south; cross on sandstone, marked " 1733 " .............. 1, 732.54

Saltville, 5.8 miles west of, on road to Hayter Gap, 575 feet west of road forks south, about 0.8 mile southwest of Hazel Springs, 75 feet east of where creek crosses road, 6 feet north of road, in sandstone ledge; aluminum tablet stamped " 1740 ".

Saltville, 9.3 miles east of, on road to Hayter Gap, 100 feet north of forks north where road goes over Hayter Gap, 16 feet west of road, in sandstone ledge; aluminum tablet stamped " 1656 "....................., 655.950

Hayter Gap, 1 mile south of, on road to Abingdon, 10 feet northwest of road forks east, at east end of bridge over Wolf Creek, 150 feet northeast of junction of North Fork Holston River and Wolf Creek; cross on rock,

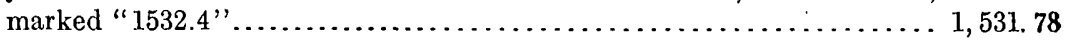

Hayter Gap, 1 mile south of, on road to Abingdon, 100 feet northeast of bridge over Wolf Creek, 75 feet northeast of road forks east, 10 feet east of road, in ledge of rock; aluminum tablet stamped " 1536 " ......... 1, 535. 202

Hayter Gap, 4.7 miles south of, on road to Abingdon, 6 feet north of road forks south; cross on ledge of rock near house, marked " 1498 ". ....... 1, 497. 32

Hayter Gap, 6 miles south of, on road to Abingdon, 7 feet east of road, 50 feet south of store, on north bank of Tool Creek; cross on ledge of rock, marked " $1500 "$ "..................................... 1,499.62

Hayter Gap, 6 miles south of, on road to Abingdon, 75 feet south of Baily's store on Tool Creek, 15 feet east of where road crosses Tool Creek, in ledge of rock; aluminum tablet stamped " 1503 "................... 1, 502.043

Hayter Gap, 9.8 miles south of, 1 mile southwest of White's mill, on road to Abingdon, 20 feet northwest of second-class road west, 300 feet south of creek crossing, in ledge of rock; aluminum tablet stamped " 2008 "...... 2, 007. 636 
HAYTER GAP, NORTHEAST ALONG HIGHWAYS, TO BELFAST MILLS (SPUR LINE).

Hayter Gap, 2.4 miles north of, on top of Clinch Mountain, in Hayter Gap, Feet.

10 feet west of road, in sandstone ledge; aluminum tablet stamped " 3012 ". $3,010.920$

Hayter Gap, 4.6 miles north of, northeast of road forks east, 75 feet west of where Soop Creek crosses road, about 0.25 mile south of Rockdell; cross on rock, marked " 2188.3 "

$2,187.67$

Hayter Gap, 6.1 miles north of, about 300 feet south of road forks west, leading to Elk Garden, 6 feet east of road, in limestone ledge; aluminum tablet stamped " 2131 "

old Rosedale, about 400 yards east of, 150 feet west of road forks north, leading to Honaker, 8 feet north of road, in limestone ledge; aluminum tablet stamped " 2281 "........................................ 2, 280. 669

Rosedale, about 2.5 miles east of, 30 feet southwest of road forks north, south side of road; cross on rock, marked " 2330.6 " ............... 2,330. 03

Rosedale, 2.8 miles east of, about 0.25 mile west of John Vessel's residence, 100 feet south of road forks, 10 feet east of road, in sandstone; aluminum tablet stamped " 2314 ". ................................. 2, 313.810

Belfast Mills, 20 feet west of forks, 35 feet east of blacksmith shop; cross painted on rock, marked " $2280 "$ "......................... 2, 279. 15

Belfast Mills, 1 mile east of, 75 feet south of road, 300 feet northeast of C. W. Grant's residence, 6 feet north of branch of Indian Creek, in limestone ledge; aluminum tablet stamped " 2293 " 


\section{INDEX.}

A.

Abbyville.

Aberdeen.

Abingdon.

A bingdon quadrangle.

Accident

Accident quadrangle. . . . . . . . . . . . . . .

Ajax.

Alberton.

Alleghany

Allibone.

American Corners.

Ammendale.

Annapolis.

Annapolis Junction

Annapolis quadrangle.

Appomattox quadrangle.

Aqueduct Bridge

Arsenal grounds

Ashton.

Avalon...

Avondale.

B.

Backbone.

Bacons Castle.

Bailey, C. B., work of .

Bailey, G., work of.

Baldwin, D. H., work of ......................

Baltimore

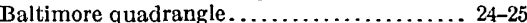

Barclay.

Barclay quadrangle.

Barnesville.

Bartholows.

Bassett.

Battery Park

Bayview.

Beatrice.

Belair

Belair quadrangle.

Belfast Mills.

Beltsville.

Benfield.

Benton Corners

Berlin.

Berwyn

Betterton quadrangle.

Bissell.

Blacks

\begin{tabular}{|c|c|c|}
\hline & & \\
\hline 55 & Blades & 11 \\
\hline 22 & ington.. & 46 \\
\hline 65 & Blue Mountain........ & \\
\hline-68 & Bluestone Creek....... & \\
\hline 46 & 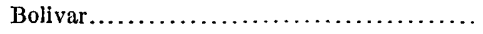 & \\
\hline 46 & Mills............. & \\
\hline 59 & .................. & \\
\hline 27 & 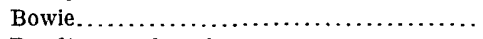 & \\
\hline 52 & |rangle ... & -6 \\
\hline 23 & Bra & \\
\hline 23 & ........... & \\
\hline o. & $\ldots$ & \\
\hline 3 & $\cdots$ & \\
\hline 28 & $\cdots$ & \\
\hline & ...... & \\
\hline o). & Bro & \\
\hline 60 & $\mathrm{BrC}$ & \\
\hline 00 & $\mathrm{Br}$ & \\
\hline & Bri & \\
\hline 3 & urch... & \\
\hline 2 & $\mathrm{Brl}$ & \\
\hline \multirow[t]{3}{*}{38} & n............ & \\
\hline & ........... & \\
\hline & , work of... & \\
\hline 5 & $\mathrm{Bu}$ & \\
\hline 5 & $\mathrm{Bu}$ & \\
\hline 4 & $\mathrm{Bu}$ & \\
\hline 0,21 & & \\
\hline 51 & & \\
\hline & Burtonsville........... & \\
\hline
\end{tabular}

C.

Callaghan........................... 52

Calvert................................ 22

Cambridge........................... 17

Camden.............................. ${ }_{25}$

Campbell............................... 21

Campbell, N. A., work of................. 47

Capital Traction Building ................. 14

Capitol................................ 13

Catoctin............................... 40

Catonsville............................ 24

Cavetown............................ 41

Cayots Corners....................... 16

Cecilton quadrangle.................... 16

Cedar Forest............................ 57

Cedar Grove............................ 34

Centerville............................... 8,17

Charlestown.......................... 22

Charlesville............................. 32

Chatham Hill........................ 67

Cherry Run ......................... 44

Chesapeake........................... 22

46

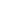

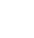

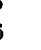

49

9

30

67 67
13

0

8

8

14

1

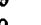

30




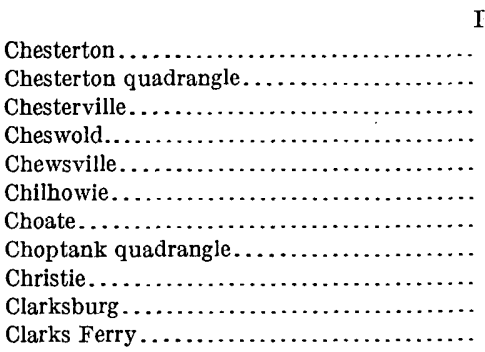

Clarksville.

Clarksville Junction.

Clarksville quadrangle.............. 48,55-56

Clarkton........................... 57

Clarysville......................... 45

Clayton............................ 9

Clifton Forge........................ 51

Clifton Forge quadrangle............... 51

Clover......................... 56,57

Cloverdale.......................... 50

Clover quadrangle.

Clunet, C. A., work of ................. 15

Cluster Springs..................... 60

Coates, W. G., work of................. 24

Cockeysville......................... 25

Colburne........................ 21

Coles Ferry......................... 57

Columbia........................ 30

Conaways........................... 28

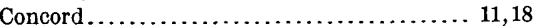

Conowingo ........................ 22

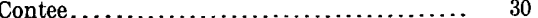

Couches Bridge..................... 8

Covington............................ 51

Crabster............................ 39

Crapo quadrangle...................... 19

Crisfield........................... 20

Crisfield quadrangle.................. 20

Croaker Hill. . . . . . . . . . . . . . . . . 52,53

Crystal Hill...................... 57

Cumberland ........................... 45

Cumberland Gap..................... 64

\section{D.}

Dagsboro.

Daingerfield, J. S. B., work of........... 21

Damascus..................... 31,65,66

Darlington......................... 22

Darnestown .......................... 35

Dawsonville...................... 35

Day................................ 31

Daysville........................... 63

Deal Island quadrangle................. 20

Deemer, R. S., work of ................. 52

Deerfield ......................... 40

Deer Park. ........................ 46,59

Deerwood Fork .................. $\quad 59$

Delaware.......................... 7-13

Denbigh . . . . . . . . . . . . . . . . . 53

Denniston............................. 60

Denton............................. 18

Denton quadrangle..................... 18

Detour .......................... 38,39

Dillon............................. 61

District of Columbia

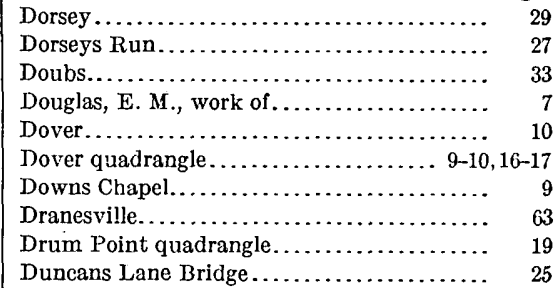

E.

Eagle Point. ..................... 60

Eagle Rock........................ $\quad 51$

Earleville....................... 16

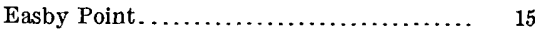

East Allegheny . . . . . . . . . . . . . . . $\quad 52$

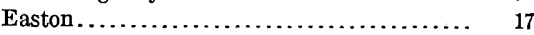

Eckington. ...................... 13

Eden........................... 20

Edesville........................ 17

Edgemont. ...................... 41

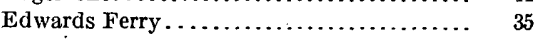

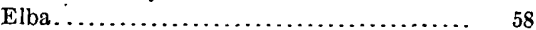

Elioak . . . . . . . . . . . $\ldots \ldots \ldots \ldots \ldots \ldots$

Elk Ridge. . . . . . . . . . . . . . . . . $\quad 29$

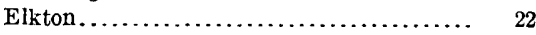

Elkton quadrangle................... $\quad 22$

Ellendale. . . . . . . . . . . . . . . . . . 10

Ellendale quadrangle................. 10

Ellerton.......................... 42

Ellicott City . . . . . . . . . . . . . . . 26

Ellicott City quadrangle.............. 26-27

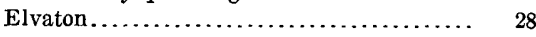

Emmitsburg ..................... 40

Emmitsburg quadrangle. ............... 39-40

Emory ..................... 65,66

\section{F.}

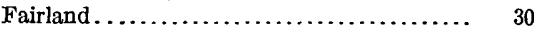

Fairlee. . . . . . .

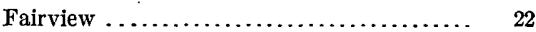

Faith Chapel...................... 14

Falls Mills. ...................... 63

Farmer, R. A., work of. . . . . . . . . . . 31, 62

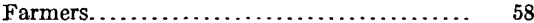

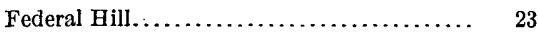

Federalsburg........................... 18

Ferrum . . . . . . . . . . . . . . . . 49

Fincastle.......................... 62

Fincastle quadrangle............... 50-51,62

Flattop. .......................... 63

Flintstone........................... 44

Flintstone quadrangle. ................. $44-45$

Florence. . . . . . . . . . . . . . . . . . . 31

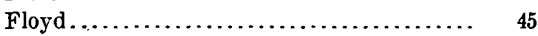

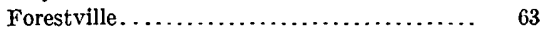

Foust, F. L., work................. 64

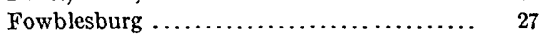

Fowling Creek ........................ 18

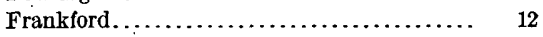

Frankford quadrangle.................. 12

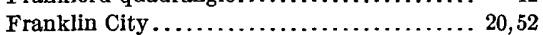

Frederick . . . . . . . . . . . . . . . . . . 32,33

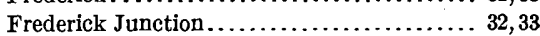

Fredericktown ..................... 16

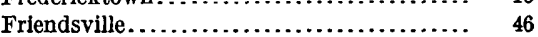


Page.

Frostburg

Frostburg quadrangle

Funkstown

Gaither

Gaithersburg

Gala.

Galt.

Gamber...

Gannett, S. S., work of.

Gapland.

Garrett Park

Gay street.

Germantown

Georgetown

Ceorgetown quadrangle.

Gilman, H. M., jr., work of

Gilmore Mills.

Glade Hill.

Glasgow.

Glenburnie.

Glen Wilton

Gloucester..

Gloucester Point.

Golden Hill.

Goldsborough, C., work of

Gorman

Gorsuch.

Goshen..

Graceham ...............................

Grafton.

Graham

Granogue.

Grantsville.............................

Grantsville quadrangle.

Grays.

Great Falls.

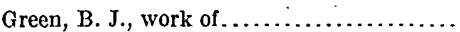

Green, T. A., work of............... 31,52,61,63

Green Hill

Green Ridge.......................... 44

Greenwood ............................. 10

Griffin.............................. 18

Grimes............................. 37,43

Grit.................................. 58

Grove............................. $\quad 53$

Guilford quadrangle.................... 52

Gum Swamp ......................... 19

\section{H.}

Haden

Hagerstown

Hagerstown quadrangle.................. $41-43$

Halbert, E. O., work of.................... 55

Halethorpe............................ 29

Halfway .............................. 43

Halsteads Point......................... 53

Hampstead.............................. 27

Hampton............................. 55

Hampton quadrangle..................... 54-55

Hancock............................. 44

Hancock quadrangle...................... 44

Hanesville.............................. 17

Hanover.

Harpers Ferry
Harrington Page

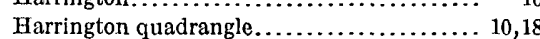

Harris, J. M............................ 35, 38

Hartley ............................. 9

Harwood ...................................

Havre de Grace......................... 23

Havre de Grace quadrangle................ 22-23

Hayter Gap............................. $67-68$

Hazels Corners. . . . . . . . . . . . . . . . . . 9

Henry................................ 48

Henrytown........................... 27

Herring Run........................... $\quad 25$

Heurich brewery ..................... 15

Highfield............................. 40

Highgate............................ 54

High Point ......................... 23

Hillsboro............................. 18

Hobbs.............................. 18

Hockessin ............................. 8

Hodges, J. W., work of......... 8, 15, 16, 21, 24, 52

Hollingsworth........................ 10

Hollins............................... 50

Hollofield ............................. 26

Hoods Mills .......................... 32

Horton, A. H., work of................... 55

Houston............................. 60

Hoyes................................ 46

Hurlock quadrangle..................... 18

Hurt................................ 58

Hutchins, R., work of.................. 15,24, 31

Hyattstown.......................... 32

\section{I.}

Ijamsville............................ 33

Ijamsville quadrangle.................. $32-33$

Ilchester............................... 26

Indianrock...............................

Ingleside.............................. 16

Iron Gate............................... 51

Island Creek......................... 59

Isle of Wight quadrangle................. 54

\section{J.}

Jamestown.$\ldots \ldots \ldots \ldots \ldots \ldots \ldots \ldots \ldots \ldots \ldots \ldots$

Jamestown quadrangle................... 54

Jefferson............................... 36

Jerrys Run ........................... 52

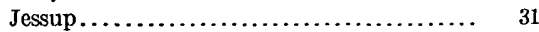

Jones............................... 28

K.

Kearney........................... 46

Keedysville.......................... $\quad 37$

Kendall Green Baptist Church............ 14

Kensington.......................... 34

Keyser ............................... 45

Kings Corners........................ 54

Kingsdale............................. 39

Klej Grange.......................... 20

Knowles.............................. 12

Knowles Crossroads...................... 11

Konnarock......................... 65,66

\section{L.}

Lacks Ferry ........................ 56

Ladiesburg............................ 38

35,37 Lake Royer............................ 41 


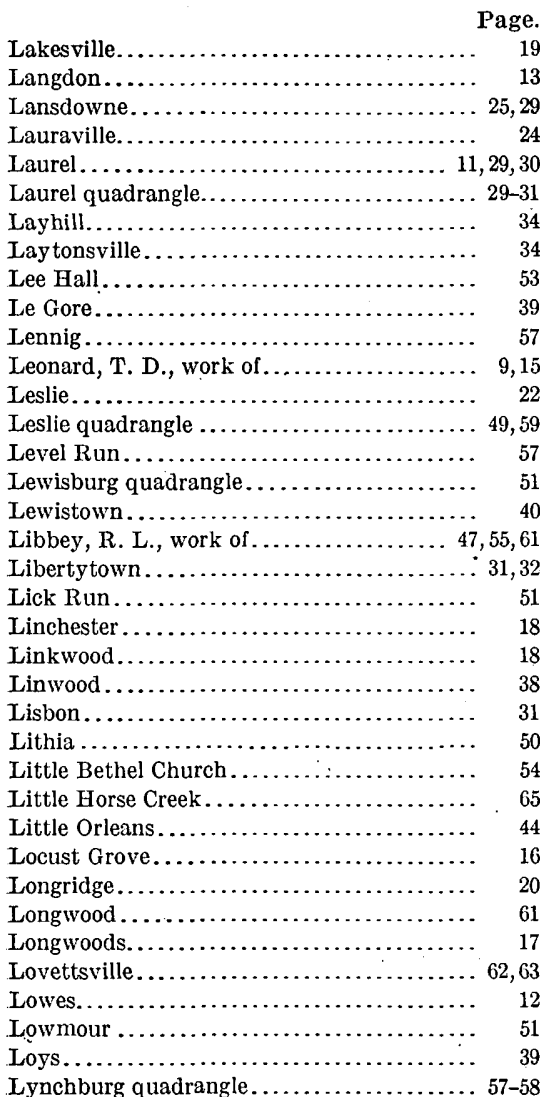

M.

McAleer....

McDonough ...........................

McGinnes............................. 16

McKeever Ferry ...................... 57

Macton.............................. 23

Mahala............................... 63

Mallow................................. 51

Manchester.......................... $\quad 27$

Mardela Springs........................ 19

Marion........................... 20,66,67

Marriottsville........................ 27

Marshall, R. B., work of.................. 7

Martinsburg quadrangle................. $\quad 37$

Martinsville.......................... $\quad 48$

Martinsville quadrangle................. 48

Marydel............................... 16

Maryland.............................. $15-47$ aid of .............................. 7

Massey ............................... 16, 52

Mayo.................................. $\quad 60$

Meadow View......................... 65

Medford............................... 38

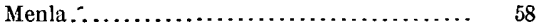

Middleburg............................ 38

Middlepoint........................... 42

Middlesboro quadrangle.................... 64

Middletown .......................... 9, 36

Middletown quadrangle............. $35-37,62-63$
Page.

Millington $. . . \ldots \ldots \ldots \ldots \ldots \ldots \ldots \ldots \ldots, 10$

Millsboro............................. 11, 12

Milton............................... 17

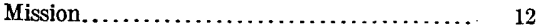

Mistletoe Springs........................... $\quad{ }_{30}$

Mondel.............................. 37

Moneta quadrangle ...................... 58-59

Monkton............................ 24

Monrovia.............................. 33

Montevideo........................... 31

Moores Place......................... 54

Moss Run.............................. 52

Motley.............................. 58

Motters.............................. 40

Mountain Lake......................... 46

Mount Airy ......................... $\quad 32$

Mount Airy quadrangle.................. 31-32

Mount Carmel.......................... 24

Mount Pleasant........................ 9,32

Mount Royal........................... 25

Mount Savage......................... 45

Mount Tabor......................... 37

Mount Vernon quadrangle................. 63

Mount Washington........................ 25

Mount Winans......................... 25

M Street Bridge ........................ 14

Muirkirk............................ 30

Murat............................... 61,62

Myersville......................... 37,42

N.

Nace............................... 50

Nanticoke quadrangle................... 19

Nathalie................................. 57

Nathalie quadrangle.................... 56-57

National Museum...................... 14

Natural Bridge ......................... 61

Natural Bridge special quadrangle ...... 50;61-62

Navy-Yard ........................... 13,14

Navy-Yard Bridge..................... 14

Neathery.............................. 57

Neersville............................ 63

Nelson.............................. 55

Nemours.............................. 64

Newark............................. 8,21

Newcastle............................ 8

New Germany .......................... 45

New London ......................... 33

New Midway........................... $\quad 39$

Newport News........................ 55

Newton .............................. 18

New Windsor.......................... 38

Noland.............................. 57

Norbeck................................ 34

North Junction........................ 41

Novelty ............................. 59

0.

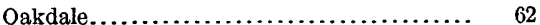

Oak Grove................................. 11, 19

Oakland.............................. 46

Oakland quadrangle ..................... 46-47

Oakley ............................... 10

Oakton ................................ 46

Oaktree............................... 53

Odenton ............................. 28

Odessa..................................... 


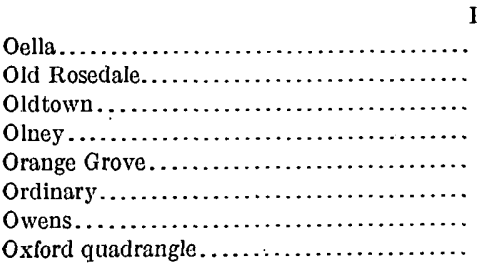

P.

Palmer, W. C., work of.

Park.

Parkton quadrangle.

Parkville.

Parsonsburg.

Pawpaw quadrangle.

Penhook.

Pen Mar

Pepper...

Perth.

Petersville.

Pettibone, O. L., work of .

Piedmont quadrangle.

Pig River.

Pikesville.

Piney Creek.

Piney Grove.

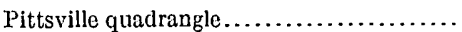

Pocahontas.

Pocahontas quadrangle..

Pocomoke City.

Poolesville.

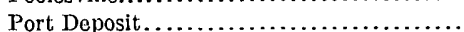

Porter Bridge...........................

Potomac.

Potomac avenue

Pratt.

Princess Anne.

Princess Anne quadranglo

Principio

Principio Furnace.......................

Pumphrey.

Pylesville.

Q.

Quantico

R.

Randolph

Rapps Mill

Redhouse

Red Lion.

Red.wood...............................

Reels Mill.

Reisterstown

Relay.

Relay quadrangle.

Reliance...

Rhodesdale.

Ridgely ... . . . . . . . . . . . . . . . . . . . .

Ridgevilte.

Ridgeway

Rising Sun

Roanoke.

Roanoke quadrangle.

Page.
26
68
45
34
29
53
10
17

Page.

Robbins............................. 10

Roberts............................. 16

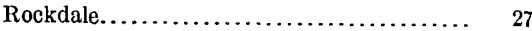

Rockville.......................... 34

Rockville quadrangle.................... $33-34$

Rocky Mount...................... 49,59

Rocky Mount quadrangle................ 48-49

Rocky Point........................... 61

Rocky Ridge......................... 39

Rohersville.......................... 30

Rosedale............................ 25,68

Ross............................... 10

s.

Sabillasville $\ldots \ldots \ldots \ldots \ldots \ldots \ldots \ldots \ldots \ldots, \quad 40$

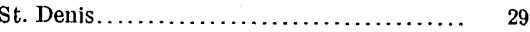

St. Georges........................... 8

St. James........................... 43

St. Michaels quadrangle.................. 17

St. Paul's A. M. E. Church ................. 14

Salisbury .......................... 20,50

Salisbury quadrangle.................... 20

Saltpetre Cave....................... $\quad 50$

Saltville.............................. 67

Sandy Hook. . . . . . . . . . . . . . . . . . . 35

Sandy Level........................ $\quad 59$

Sandy Spring.......................... 33

Sang Run............................ 46

Sassafras............................ 16,53

Saunders Siding....................... 49

Savage................................ 30

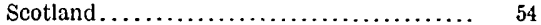

Scottsburg............................. 01

Seaford............................ 10,11

Seaford quadrangle.................... 10-11,19

Security ........................... 41

Selbyville........................... 13

Selbyville quadrangle $\ldots \ldots \ldots \ldots \ldots \ldots \ldots \ldots, 13$

Semper, C. II., work of .............. 9,16j,38,47

Seneca quadrangle................... $34-35,63$

Septa............................. 54

Seventh street power house .............. 14

Severn............................. 28

Shane............................... 23

Sharpsburg............................... 37

Sharrets............................ $\quad 39$

Shawan............................... 25

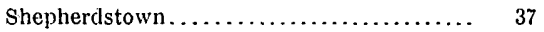

Sherwood............................ 24

Shockeys............................ 41

Signpine............................ 53

Sixmile House ....................... 44

Smith, C. M., work of.................. 21,44

Smithfield............................. 54

Smithsburg........................ 41,42

Smithsonian Institution................. 14

Smithville........................... 19

Smoketown........................... 42

Snow Hill............................ 21

Snow Hill quadrangle................ 20-21,52

Soudan................................ 48

South Boston......................... $\quad 60$

South Clarksville........................ 55,56

Sparks............................. 23

Spencerville......................... $\quad 30$

Spielman............................ 43

Spring Mills.......................... 38 


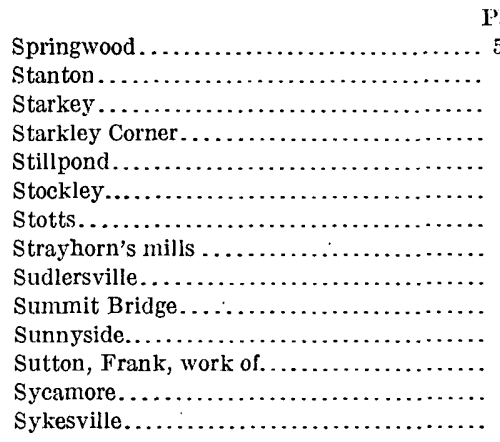

T.

Takoma Park

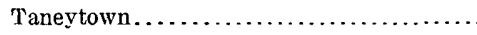

Taneytown quadrangle..................

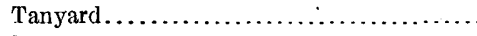

Taylor.................................

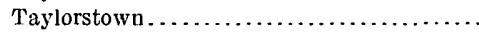

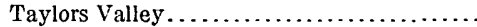

Taylorsville...

Thayerville ....................... 46,47

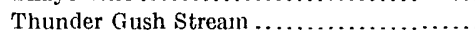

Thurmont............................ 39-40

Timonium ............................ 25

Toano quadrangle....................... 52

Tolchester quadrangle................... 17

Toshes............................... 58

Town Creek........................... 48

Townsend.............................. 9

Towson............................. 24

Trappe.................................. 17

Trinidad.............................. 13

Troutville ........................... 50

Trump............................. 23

Tufts, W. O., work of ................... 31

Tuscarora............................... 35

Twilley.

U.

Union Bridge.

Union dam.

Union Hall.

Union Mills.

Unionville.

(n................................

Urbana...............................

V.

Vale Summit.

Vienna..................................

Vineyard.

Virgilina quadrangle....................60-61

Virginia. aid of.
W.

Page

Wagners Crossroads................... $\quad 42$

Waidesboro......................... $\quad \mathbf{4 9}$

Wakefeld ............................. 38

Walkersville.......................... 32

Washington Gas Co. office................ 15

Washington Grove..................... 34

Washington Monument.............. 13,14,15

Watauga............................ 65

Waterbury $. . . \ldots \ldots \ldots \ldots \ldots \ldots \ldots \ldots \ldots, \quad 28$

Waterloo............................ 29

Watersville.......................... 32

Watkins.............................. 5

West Baltimore...................... 25

West Beaver ............................

Westchester quadrangle................. $\quad 7-8$

West End............................ 53

West Friendship........................ 26

Westminster........................ 27,38

Westminster quadrangle................. 27

Westover............................. 20

Weverton $. . \ldots \ldots \ldots \ldots \ldots \ldots \ldots \ldots \ldots \ldots \ldots \ldots, 35,36$

Wheaton............................. 34

Wheeler............................. 64

Whiteburg.............................

Whitehall............................ 24

Whitehall crossroads..................... 9

Whitehaven.......................... 19

Whiteleysburg........................ 18

Whitemarsh.......................... $\mathbf{5 3}$

Williamsburg........................

Williamsburg quadrangle............... 53

Williamsport.......................... 43

Williamsport quadrangle................ 43

Williston........................... 18

Wilmington............................ 8

Wilmington quadrangle............... 7,8-9

Wilson, H. M., work of................. 7

Winans........................ 28

Wingate ............................. 19

Winstead, W. R., work of ............... 35,62

Winthrop Heights..................... 13

Wirtz............................ 49

Wolfsville.......................... 42

Wolftrap.......................... 60,61

Wood, H., work of . . . . . . . . . . .

Woodbine.......................... 31,32

Woodenburg......................... $\quad 27$

Woodsboro........................... 39

Woodside............................. 10

Woodstock........................... 26, 27

Wright.............................

W ye Mills............................ $\quad 17$

Wyoming............................ 10

\section{Y.}

Yorktown........................... 53,54

Yorktown quadrangle.................. 53-54 